\title{
Togo: 2011 Article IV Consultation and Sixth Review Under the Extended Credit Facility Arrangement-Staff Report; Public Information Notice and Press Release on the Executive Board Discussion; and Statement by the Executive Director for Togo
}

Under Article IV of the IMF's Articles of Agreement, the IMF holds bilateral discussions with members, usually every year. In the context of the combined discussion of the 2011 Article IV consultation and sixth review under the Extended Credit Facility Arrangement with Togo, the following documents have been released and are included in this package:

- $\quad$ The staff report on the 2011 Article IV consultation and the sixth review under Extended Credit Facility arrangement, prepared by a staff team of the IMF, following discussions that ended on May 13, 2011, with the officials of Togo on economic developments and policies. Based on information available at the time of these discussions, the staff report was completed on July 7, 2011. The views expressed in the staff report are those of the staff team and do not necessarily reflect the views of the Executive Board of the IMF.

- $\quad$ A Public Information Notice (PIN) and Press Release summarizing the views of the Executive Board as expressed during its July 18, 2011 discussion of the staff report that concluded the Article IV consultation and the Sixth Review Under ECF arrangement.

- $\quad$ A statement by the Executive Director for Togo.

The document listed below has been or will be separately released.

Letter of Intent, the Public Informational Notice, and the Press Release *Also included in Staff Report

The policy of publication of staff reports and other documents allows for the deletion of market-sensitive information.

\author{
Copies of this report are available to the public from \\ International Monetary Fund • Publication Services \\ $70019^{\text {th }}$ Street, N.W. • Washington, D.C. 20431 \\ Telephone: (202) 623-7430 • Telefax: (202) 623-7201 \\ E-mail: publications@imf.org Internet: http://www.imf.org
}

\section{International Monetary Fund Washington, D.C.}




\title{
INTERNATIONAL MONETARY FUND
}

\section{TOGO}

\section{Staff Report for the 2011 Article IV Consultation and Sixth Review Under the Extended Credit Facility Arrangement}

\author{
Prepared by African Department \\ (In consultation with other departments)
}

Approved by Michael Atingi-Ego and Thomas Dorsey

July 7, 2011

\begin{abstract}
Discussions: Lomé, April 26 - May 13, 2011. The team comprised Mr. Mills (head), Ms. Niangoran, Messrs. David, Lonkeng Ngouana, and Ruggiero (all AFR), Mr. Sarr (resident representative), and Mr. Bah (OED) also participated in the discussions. The mission met the President of the National Assembly Bonfoh, the Prime Minister Houngbo, the Finance Minister Ayassor, the BCEAO National Director Tenou, and other senior officials.
\end{abstract}

Relations with the IMF: Togo's three-year ECF arrangement was approved in April 2008, for SDR 66.06 million (90 percent of quota). Augmentations of access of SDR 18.35 million ( 25 percent of quota) and SDR 11 million (15 percent of quota) were approved in September 2008 and June 2010, respectively. The HIPC completion point was reached in December 2010. The authorities have met all performance criteria and achieved satisfactory progress on structural benchmarks for the sixth review. In the attached Letter of Intent, they request completion of the review, to be followed by the opening of negotiations on a successor IMF-supported economic program. With completion of the sixth review, the final disbursement of SDR 8.8 million will be made available.

Past advice: The previous Article IV consultation was concluded in April 2009. The IMF and the authorities agreed that fiscal discipline and timely implementation of structural reforms were critical to reviving and sustaining economic growth. Top structural priorities were reforms in the financial sector, public enterprises and fiscal governance, including improving investment spending execution.

Article IV consultation: The discussions focused on policies to raise growth potential and external competitiveness, while maintaining macroeconomic stability, particularly by (i) scaling up public investment in infrastructure, improving the business climate, and reforming state-owned banks and enterprises; and (ii) continuing to strengthen public finances, both in terms of management and sustainability.

Outreach and seminars: Staff and the authorities held seminars on: (i) public investment, growth, and debt sustainability; (ii) fiscal policy rules; (iii) competitiveness and exchange rate assessment; and (iv) medium-term outlook and debt sustainability. Seminars on (i) and (ii) were also held at the university. The mission also met with representatives of parliament, labor unions, employer associations, NGOs, donors, and media.

Exchange restrictions and regime: Togo, a member of WAEMU, accepted the obligations of Article VIII, Sections 2, 3, and 4 of the IMF's Article of Agreement on June 1, 1996 and maintains an exchange system that is free of restrictions on current international transactions. WAEMU's common exchange rate regime is a conventional peg to the euro. The BCEAO conducts monetary and exchange rate policies for the region. Banks are supervised by the WAMU Banking Commission. 
Abbreviations . .4

Executive Summary .5

I. Recent Developments and Near-Term Outlook: Gradual Recovery ..................................6

II. Program Performance: Strong on Budget, Mixed on Structural Reforms ..........................10

III. Article IV Discussions: Building Growth Momentum.................................................16

A. Strengthening the Foundations for Medium Term Growth .......................................16

B. Sustainable Growth-Promoting Fiscal Policies .......................................................18

C. Strengthening Pro-Growth Structural Policies ...................................................22



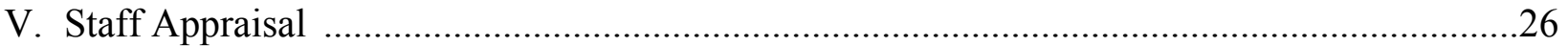

Boxes

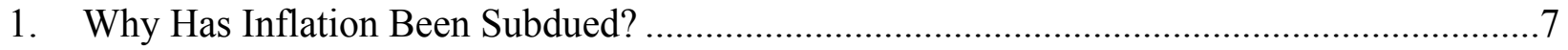

2. Impact of Reforms in Agriculture Following the 2008 Crisis..........................................10

3. Response to Fund Advice in the 2009 Article IV Discussions ...........................................17



5. Exchange Rate Assessment and Non-Price Competitiveness ...........................................23



Figures

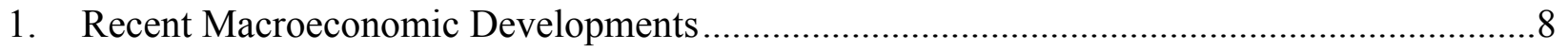

2. Moderate Impact of Adverse External Environment ...................................................9

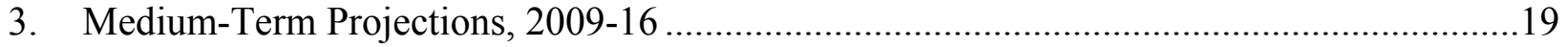



Tables

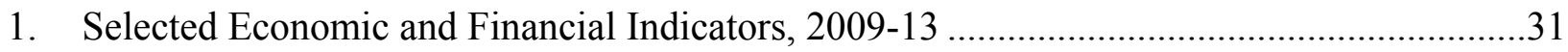

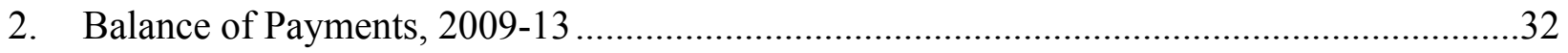

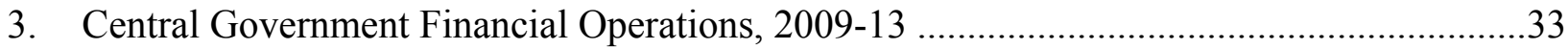

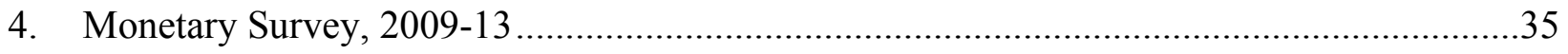

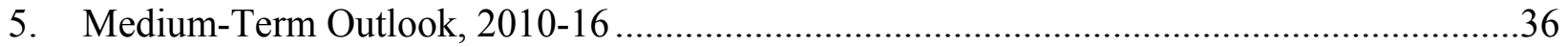

6. Actual and Proposed Schedule of Disbursement Under ECF Arrangement, 2008-11 ...........37

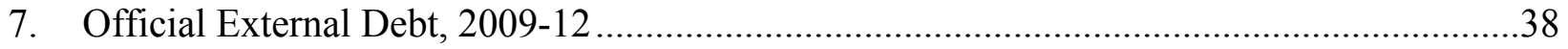

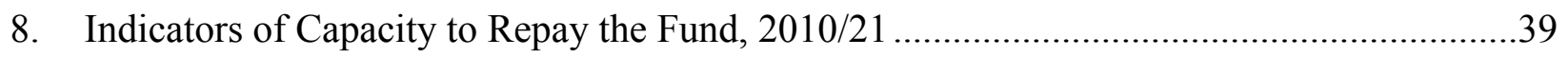

9. WAEMU Convergence Criteria, 2007/12 ...................................................................... 40 
10. Selected Indicators on the Millennium Development Goals, 1990/2009.

Appendices

I. Letter of Intent .43

Table 1. Quantitative Performance Criteria and Indicative Targets ...............................51



Table 3. Structural Conditionality for the ECF Program in 2011 ...................................53

II. Update of the Debt Sustainability Analysis (DSA) Using the Low-Income



III. Linking Public Investment, Growth and Debt Sustainability.......................................66

IV. A Framework for Growth-Supporting Fiscal Rules ..................................................72 


\begin{tabular}{|c|c|}
\hline \multicolumn{2}{|r|}{ ABBREVIATIONS } \\
\hline BCEAO & $\begin{array}{l}\text { Banque Centrale des Etats de l'Afrique de l'Ouest (Central Bank of West African } \\
\text { States) }\end{array}$ \\
\hline BTCI & $\begin{array}{l}\text { Banque Togolaise Pour Le Commerce Et L'Industrie (Togolese Trade and } \\
\text { Industrial Bank) }\end{array}$ \\
\hline BIA-Togo & $\begin{array}{l}\text { Banque Internationale Pour L'Afrique Au Togo (International Bank for Africa- } \\
\text { Togo) }\end{array}$ \\
\hline BOAD & Banque Ouest Africaine de Développement (West African Development Bank) \\
\hline CEB & Communauté Electrique du Benin \\
\hline CEET & Compagnie Energie Electrique du Togo (Electric Energy Company of Togo) \\
\hline CNADI & $\begin{array}{l}\text { Comité Nationale d'Apurement de la Dette Intérieure (National Committee for } \\
\text { the Settlement of the Domestic Debt) }\end{array}$ \\
\hline CRT & Caisse de retraite du Togo (Pension Fund of Togo) \\
\hline DeMPA & Debt Management Performance Assessment \\
\hline DSA & Debt Sustainability Analysis \\
\hline ECF & Extended Credit Facility \\
\hline EITI & Extractive Industry Transparency Initiative \\
\hline FDI & foreign direct investment \\
\hline FEZ & Free Economic Zone (Zone franche) \\
\hline GFS & Government Finance Statistics \\
\hline HIPC & Heavily Indebted Poor Countries \\
\hline ILO & International Labor Organization \\
\hline LOI & Letter of Intent \\
\hline MDRI & Multilateral Debt Relief Initiative \\
\hline MTEF & Medium Term Expenditure Framework \\
\hline NPL & Nonperforming loan \\
\hline OTP & Office Togolais des Phosphates (Togo's phosphate office) \\
\hline PAL & Port Autonome de Lomé (Independent Port Authority of Lomé) \\
\hline $\mathrm{PC}$ & performance criterion \\
\hline PIP & Programme d'Investissement Publique (Public Investment Program) \\
\hline PRSP & Poverty Reduction Strategy Paper \\
\hline SB & structural benchmark \\
\hline SDR & Special Drawing Rights \\
\hline SIGFIP & $\begin{array}{l}\text { Système Intégré de Gestion des Finances Publiques (Integrated Budget Execution } \\
\text { and Reporting System) }\end{array}$ \\
\hline SNPT & Société Nouvelle des Phosphates du Togo (New Phosphate Company of Togo) \\
\hline SOE & state-owned enterprises \\
\hline SOTOCO & Société Togolaise de Coton (Cotton Company of Togo) \\
\hline TMU & Technical Memorandum of Understanding \\
\hline UNDP & United Nations Development Program \\
\hline UNICEF & United Nations International Children Emergency Fund \\
\hline UTB & Union Togolaise de Banques (Union of Togolese Banks) \\
\hline WAEMU & West African Economic and Monetary Union \\
\hline WAMU & West African Monetary Union \\
\hline WFP & World Food Program \\
\hline WHO & World Health Program \\
\hline
\end{tabular}




\section{Executive Summary}

Togo's economic performance continued its gradual improvement in 2010, marking progress in overcoming the legacy of its protracted domestic crisis (1990-2005). Economic growth has accelerated progressively, reaching 3.7 percent in 2010 and a projected 3.9 percent in 2011 despite unfavorable external economic conditions. Macroeconomic stability has also improved. Public finances have strengthened markedly, thanks to external debt relief under the HIPC initiative and prudent fiscal policy. Despite global price shocks, inflation has remained moderate, and the current account deficit, while growing somewhat, has remained financed in a sustainable manner.

Thanks to strong implementation, Togo's IMF-supported economic program has broadly achieved its objectives in 2010. Budget execution was particularly strong in 2010, and all performance criteria were met by ample margins. Moreover, investment and social spending execution improved; the increase in the former was intended in part to offset the impact of the adverse external environment. The program's structural reforms continued to advance in 2010.

The improving economic performance and sound policies generally continued in early 2011, despite the adverse impact of the global oil price shock, particularly on fiscal policy. Concerned with social stability, the authorities initially did not pass through the global oil price rise to consumers, which led to costly and poorly targeted generalized price subsidies. To maintain a sustainable fiscal framework in 2011, the authorities adjusted their policy approach in June, by: beginning to implement a previously adopted automatic price adjustment mechanism, with a smoothing formula; offsetting partially the costs incurred with spending savings; and taking temporary, targeted social measures to cushion the social impact. Stronger public finances have enhanced economic confidence substantially; care should be taken to preserve these hardwon gains. Despite ongoing progress, implementation of certain structural reforms has lagged behind plans in 2011. In particular, preparations for bank privatization - a cornerstone of the program - have begun moving quickly only recently. Capacity constraints have proven an obstacle, highlighting the importance of continued public sector reform.

The Article IV consultation discussions focused on fiscal and structural policies to achieve higher economic growth while maintaining stability. A planned temporary scaling up of public investment in 2012-14 can support growth without compromising stability under the authorities' current policy plans. Continued public financial management reforms are particularly important in this context. Institutionalizing the commitment to sustainable fiscal policies will also be important, for example through adoption of a formal policy rule.

Accelerated structural reforms are key for robust, sustained and quality growth. These reforms also offer important means to enhance Togo's competitiveness. Its real effective exchange rate is broadly in line with fundamentals. Priority sectors for reform are banking, phosphate, telecommunications and energy, where the state plays large roles. 


\section{RECENT DEVELOPMENTS AND NEAR-TERM OUTLOOK: GRADUAL RECOVERY}

1. Economic performance continued to improve progressively in Togo in 2010, with higher growth and stronger macroeconomic stability (Figures 1 and 2, Tables 1-5).

- At an estimated 3.7 percent, economic growth in 2010 continued its gradual acceleration. Exports of goods grew only 3 percent in 2010, reflecting a difficult global economic environment and falling production in the phosphate sector. Offsetting this weakness, agricultural cash crop production, manufacturing, public works, and port activity were vibrant. While this recovery reflects progress in mitigating the adverse legacy of Togo's protracted domestic crisis and unfavorable external economic conditions, growth nevertheless remains modest relative to regional standards and population growth.

- Average inflation in 2010 remained subdued at 1.4 percent, thanks largely to good local harvests and the very limited pass-through of higher global oil prices (Box 1).

- Money and credit to the private sector expanded briskly in 2010 (16 percent and 19 percent, respectively, year on year), reflecting an on-going recovery in financial intermediation. The growth of both aggregates slowed late in the year, as reserve requirements were raised in Togo as part of a WAEMU-wide harmonization.

- The current account deficit widened to 7.2 percent of GDP in 2010, up from 6.6 percent in 2009; the primary causes were higher oil prices and rising imports of intermediate and capital goods, linked in part to higher public investment. Offsetting this deterioration, capital inflows increased (notably bond purchases, project loans and mobile phone license fees), reflecting a recovery in economic confidence.

2. The gradual improvement in economic performance and growth is expected to continue in 2011, in a generally stable macroeconomic environment. Agricultural production, manufacturing, and public works will likely be the main contributors to growth, projected at 3.9 percent. Instability in Cote d'Ivoire has had a broadly neutral net impact on growth in Togo, as a shift in transit trade from Abidjan to Lomé has compensated for any disruption. Higher global oil prices will create headwinds for growth; inflation is expected to rise moderately, as retail fuel prices are adjusted and food price increases are limited by strong local production (Boxes 1 and 2). The current account deficit is projected to widen slightly because of higher global oil prices and further increases in capital goods imports linked to public investment. Capital inflows, especially FDI and project loans, are expected to finance the current account deficit fully. 


\section{Box 1. Togo: Why Has Inflation Been Subdued?}

Despite rising international food and fuel prices, inflation averaged only 1.4 percent in Togo in 2010. ${ }^{1}$ This trend is in line developments in the WAEMU region, where 2010 inflation averaged 1.3 percent.

\section{Abundant local food harvests and subsidized retail prices for petroleum products largely explain} the moderate inflation in the face of global price shocks. The large share of food in the consumption basket (29 percent) and volatile food prices have led overall monthly inflation to move in tandem with food inflation in Togo (the monthly correlation was 0.93 from 1997 to the present). Since 2009, harvests have exceeded local needs due to generally favorable weather and policy initiatives designed to address local shortages that compounded the global 2007-08 food price shock, (Box 2); this has mitigated the passthrough of rising international food prices. An uptick in inflation in late 2010 - due to certain imported food products and regional shortages linked to the Ivorian crisis - proved temporary as the rise in domestic food prices slowed sharply in early 2011. Furthermore, the Togolese authorities adjusted pump prices by only 12 percent in 2010, while international fuel prices rose 30 percent in 2010. Despite further increases in international prices in 2011, the authorities did not start adjusting retail prices until June (discussed below).
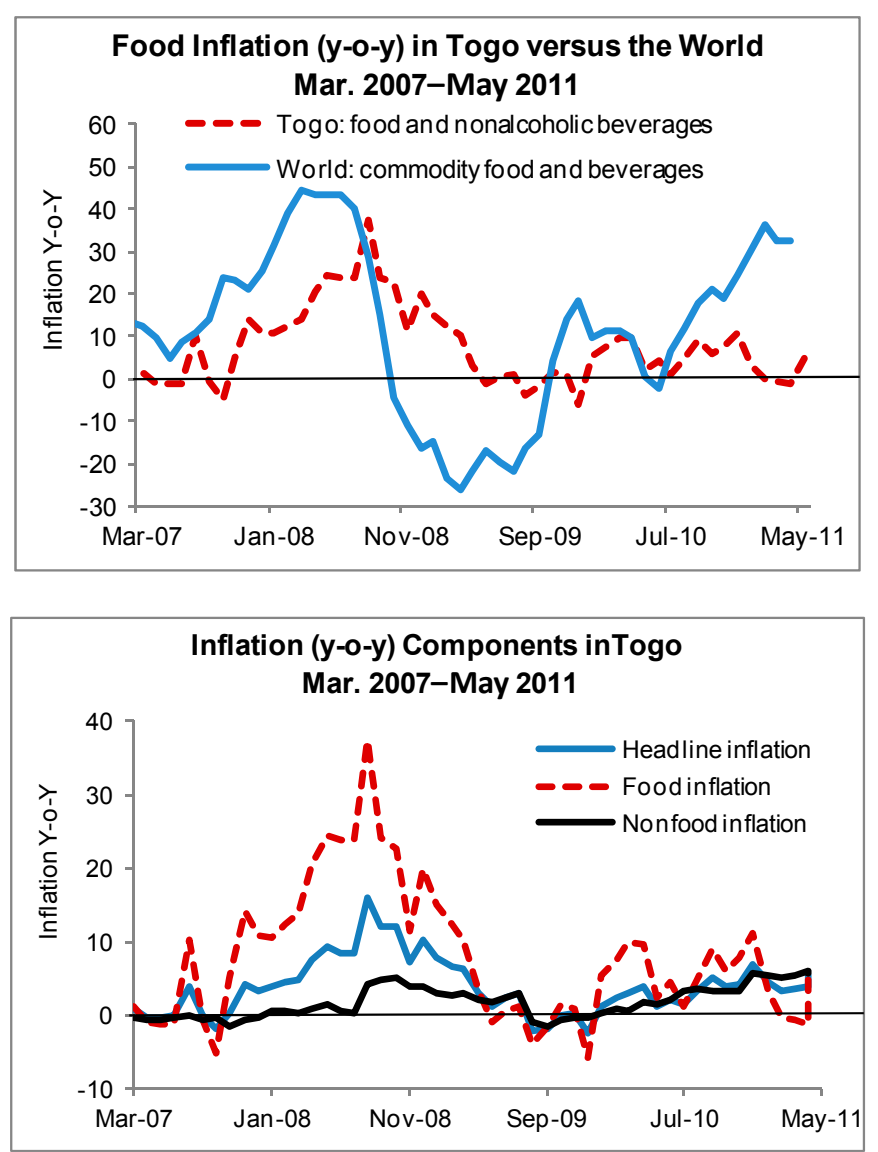

Inflation, however, is projected to pick-up in 2011, reflecting adjustments of fuel prices beginning in June. Average inflation is nevertheless expected to remain moderate at about $4 \frac{1}{4}$ percent, which is typical for the region. Abundant local food supplies are expected to continue to limit the pass-through of higher international food prices - however, this outcome is subject to significant risk, as highlighted by an uptick in food prices in May, 2011.

${ }^{1}$ The CPI basket was revised in 2010. The WAEMU commission, supported by AFRISTAT and the BCEAO, launched a revision of the harmonized CPI basket in the region in 2008. The reform included expanding CPI surveys and updating the weights of various sub-components to reflect consumption habits. To gauge the impact this adjustment might have had on actual inflation, we computed counterfactual series by applying the old weights to price indexes of CPI sub-components. The difference between the actual inflation and the resulting counterfactual inflation was minor - average inflation from the counterfactual was 1.8 percent in 2010 , only slightly above the realized inflation at 1.4 percent. 
Figure 1. Togo: Recent Macroeconomic Developments
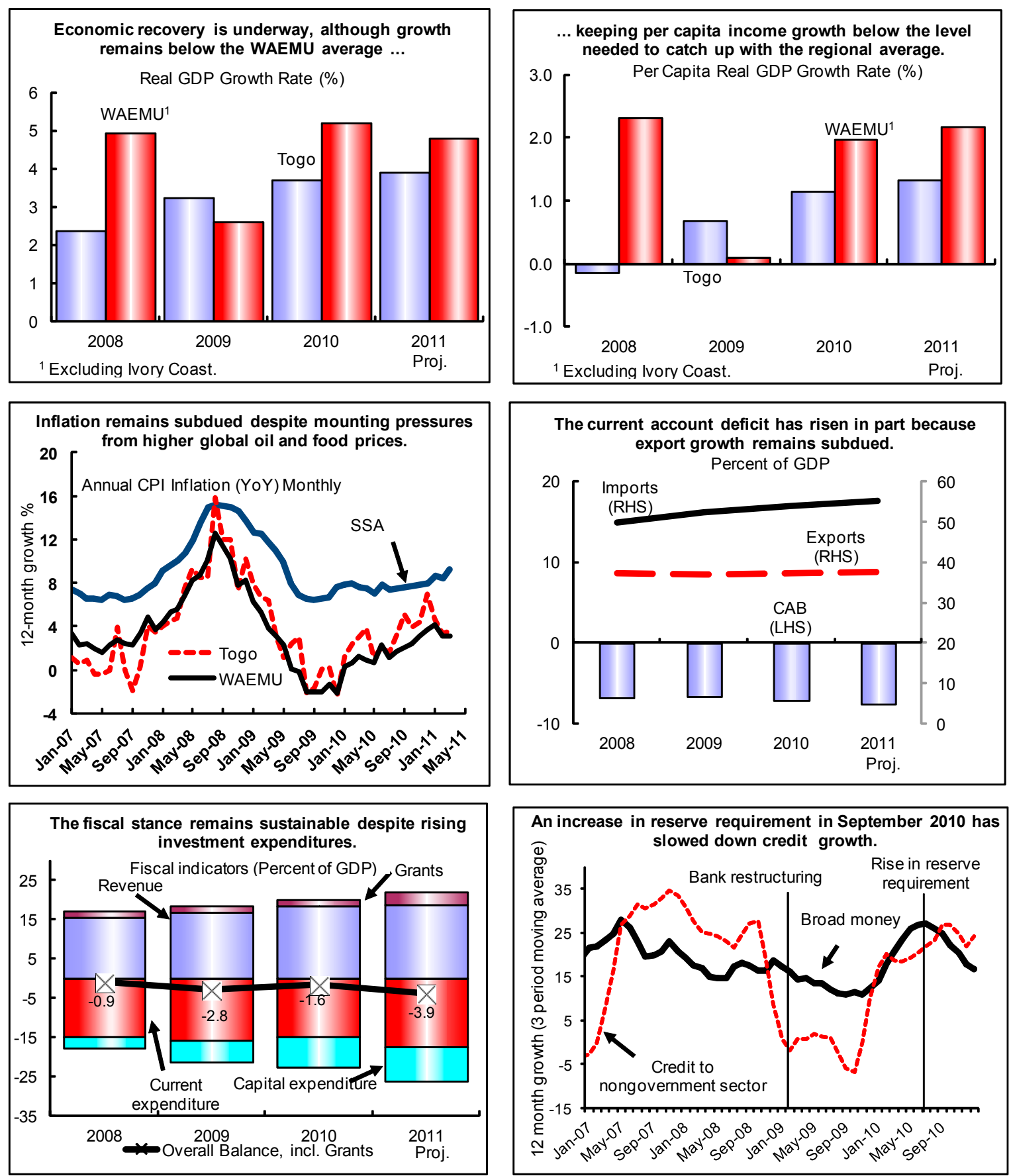

Source: Togolese authorities and IMFstaff estimates and projections. 
Figure 2. Togo: Moderate Impact of Adverse External Environment
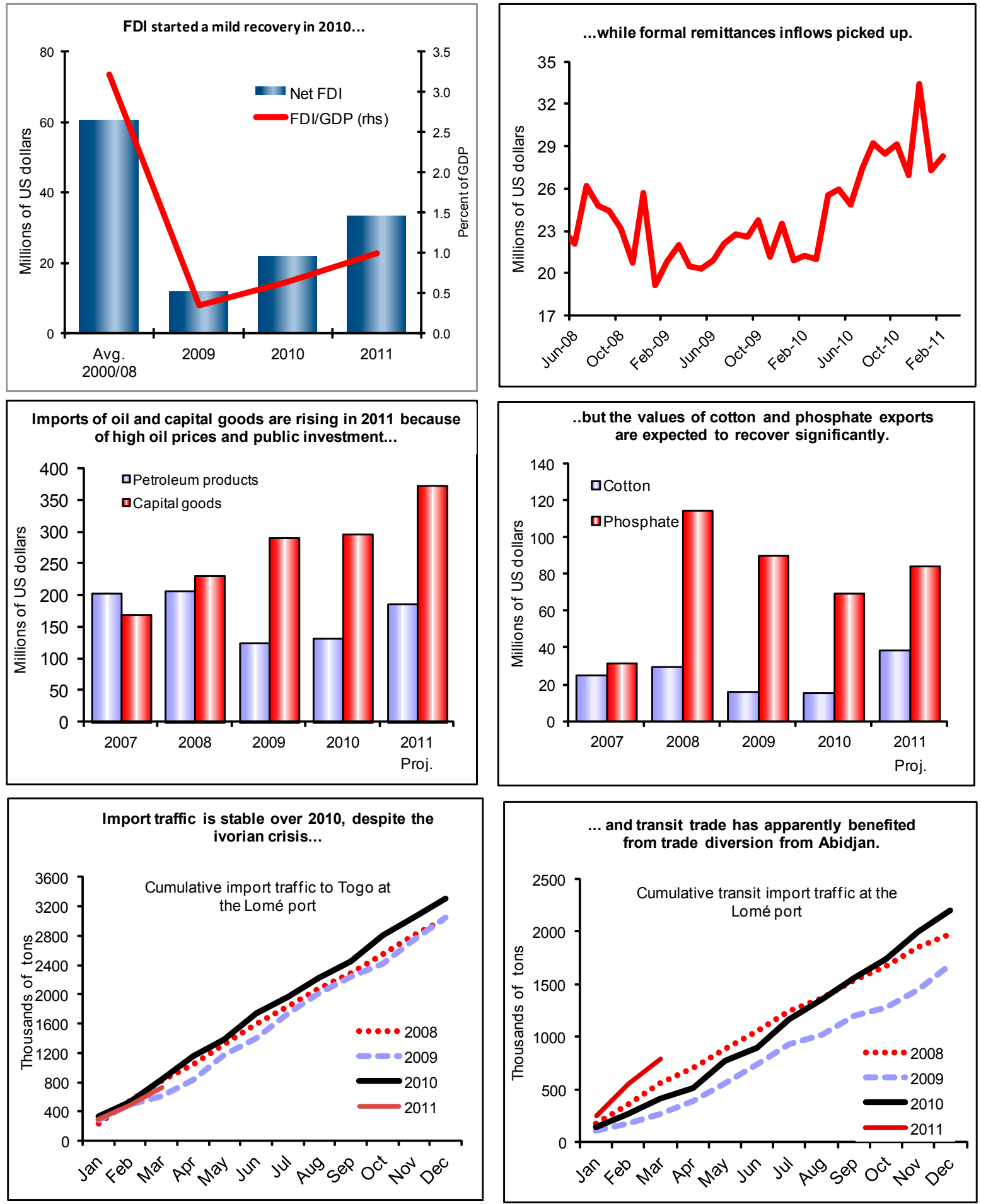

Source: Togolese authorities and IMF staff estimates and projections. 
Box 2. Togo: Impact of Reforms in Agriculture Following the 2008 Crisis

Following the 2008 crisis, the Togolese authorities implemented a three-year strategy to boost agricultural production and strengthen food security. The strategy, adopted with support from donors and the IMF, included fertilizer subsidies, increased credit to farmers for the purchase of inputs (seeds, fertilizers, etc.), and productivity monitoring. The authorities also aim to continue fostering rapid growth in the sector through an ambitious investment plan, with donor support (including the World Bank and the Food and Agriculture Organization).

Along with favorable weather, the strategy has led to bumper harvests, especially for staples. Aggregate agricultural production rose by a record high 11 percent in 2009, driven mainly by staples. Cereal production substantially exceeded local needs, which helped build stocks. While growth in agriculture slowed to 2.5 percent in 2010 , partly due to flooding in some areas, local production met local demand, protecting security stocks and moderating inflation.

A recovery in the cotton sector is also contributing to the revival in agriculture and overall growth. Cotton production doubled between 2009 and 2010; while less than 2 percent of GDP, it accounted for 0.3 percentage points of total 2010 GDP growth of 3.7 percent. In addition to the measures described above, cotton sector performance has benefitted from the pass-through of rising international cotton prices to local producers and financial restructuring of the state-owned cotton marketing company, which has led to timely payments to producers.

3. Risks and uncertainties nevertheless persist in the near-term outlook. Externally, Togo is vulnerable to more severe global price shocks that would heighten risks for growth, the current account, domestic price stability, and the budget. Domestically, social stability could be weakened by a substantial further rise in the cost of living, especially in urban areas, which might limit the government's room to pass through additional increases in global oil and food prices. Although the instability in Cote d'Ivoire has had little net impact, more protracted political instability in the region could affect growth, transit trade, and workers' remittances. As discussed below, administrative capacity constraints could delay planned reforms to address a number of persistent structural problems, thereby postponing recovery.

\section{Program Performance: Strong on Budget, Mixed on Structural Reforms}

\section{Sound Fiscal Policy}

\section{The authorities' implementation of their ECF-supported program has been} generally satisfactory, with particularly strong budget execution. In particular, they met all end-2010 fiscal PCs (LoI, \$9-10). 
- Revenue collection exceeded targets by 1.8 percentage points of GDP, because of higher-thananticipated collection of indirect taxes and non-tax revenue. Indirect tax collection benefitted from the broadening of the tax base, supported by lower direct tax rates (Text Figure 1) and administrative reforms, e.g., focus on high-return activities. Non-tax revenue doubled over 2009, thanks especially to license fees paid by mobile phone companies.

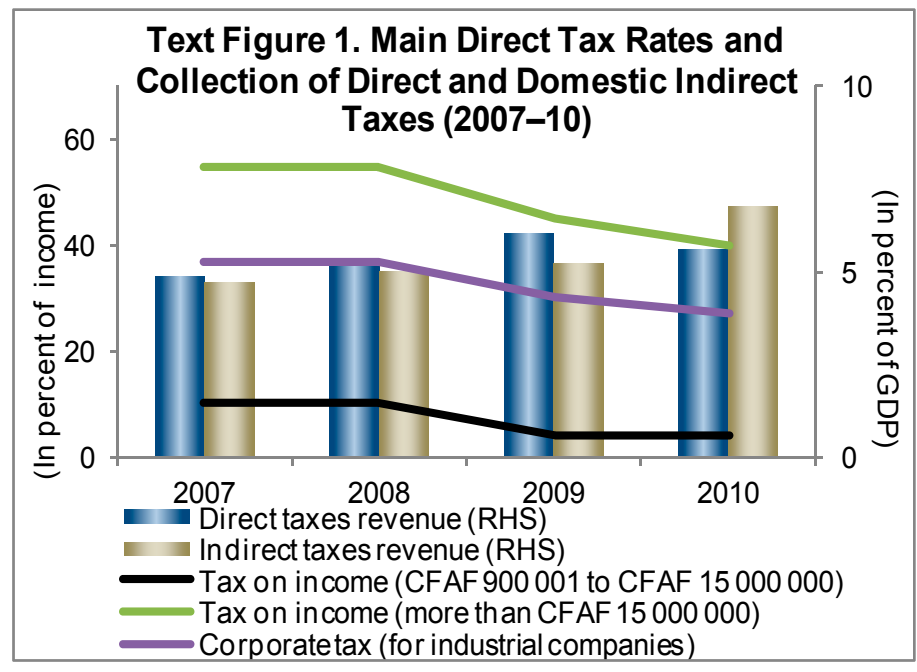

- Current expenditures were kept within program ceilings, while the execution of priority investment and social spending improved substantially. The authorities executed 91 percent of the program target for domestically financed investment spending, compared to about 71 percent in 2009. Externally financed capital and current spending reached 118 percent of program projections, as the authorities developed more capacity to take advantage of available resources thanks to training on donor procedures and an accelerated execution of ongoing multiyear projects. Priority social spending essentially reached the program target for the first time.

- As a result of strong budget execution, the PCs for the domestic primary balance and domestic financing were met by margins greater than 2 percent of GDP (LoI, Table 1). ${ }^{1}$ Fewer domestic arrears to the private sector were settled
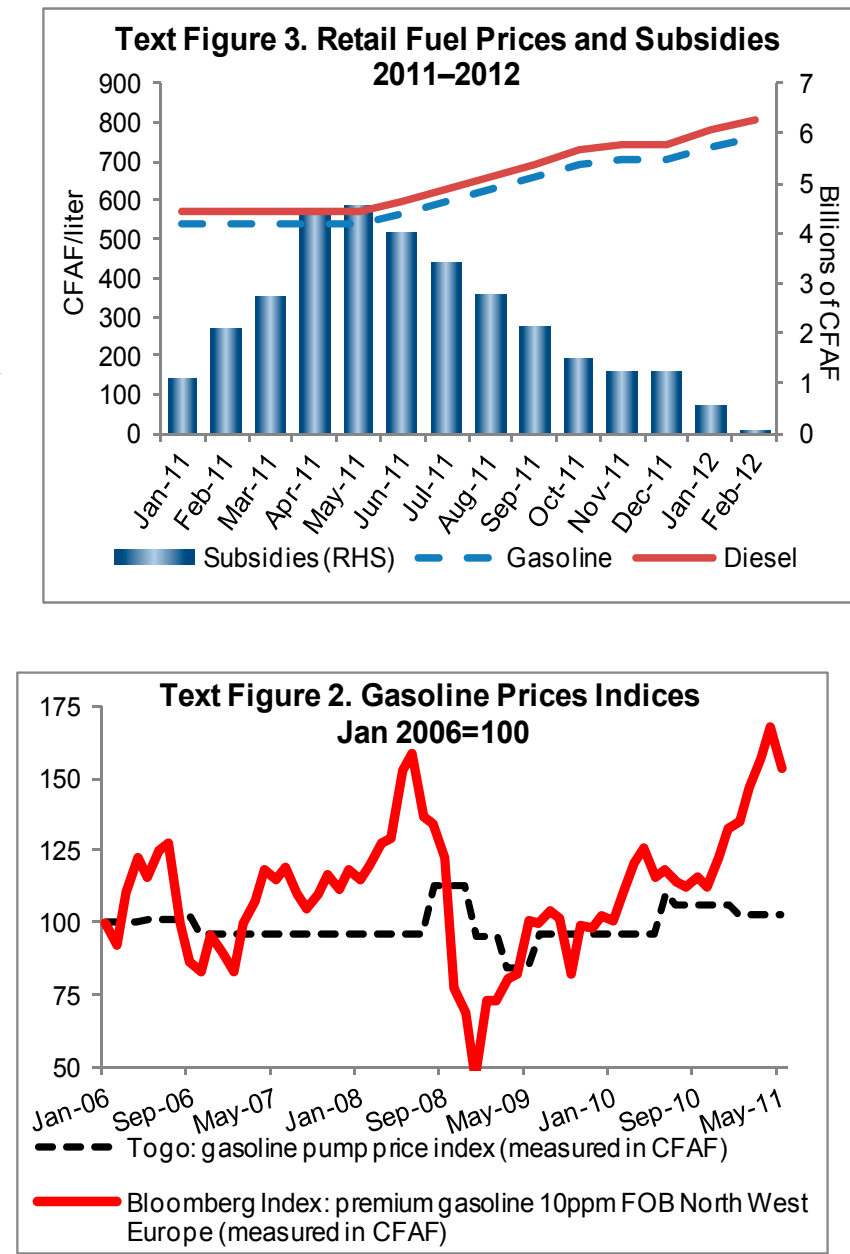
${ }^{1}$ The fiscal stance based on the budget out-turn was less expansionary than initially envisaged, since the overall
deficit on a cash basis, excluding grants, was 6 percent of GDP, 2 percentage points lower than programmed. 
than projected, as many creditors still have not come forward to claim payment.

\section{The authorities are committed to maintaining a sustainable fiscal framework in} 2011, which has required decisive action to contain the mounting costs of fixing retail prices of petroleum products (LoI, $\$ 13-16)$. Out of concern for social and political stability, the authorities did not initially pass through higher global prices to consumers, despite the adoption in December 2010 of an automatic adjustment formula with a smoothing mechanism. The resulting generalized price subsidy has an unintended regressive distributional impact and mounting fiscal costs ( 0.9 percent of GDP through May). ${ }^{2}$ Freezing prices also led to Togo having among the lowest prices in the WAEMU region (Text Table 1). Recognizing these points, the authorities started applying the mechanism in June, which will lead to monthly price increases of 5 percent and a reduction in the projected costs of fuel subsidies for JuneDecember to 0.9 percent of GDP. ${ }^{3}$ To cushion the social impact of price increases, the authorities have adopted temporary targeted social measures costing 0.2 percent of GDP. Developed in consultation with stakeholders, these measures include eliminating taxes on providers of public transport and granting a transportation allowance to workers and pensioners earning less than $\$ 2.50$ per day, as well as university students. To limit the increase in the budget deficit, the authorities also decided to offset the costs of the subsidies through May by postponing the equivalent amount of investment spending ( 0.9 percent of GDP).

Text table 1. Petroleum products prices in WAEMU, Ghana and Nigeria (CFAF per liter, Dec. 2010 - Jun. 2011)

\begin{tabular}{|c|c|c|c|c|c|c|c|c|}
\hline & \multicolumn{4}{|c|}{ Gas oline } & \multicolumn{4}{|c|}{ Diesel } \\
\hline & Dec-10 & Jan-11 & May-11 & $\overline{\text { Jun-11 }}$ & Dec-10 & Jan-11 & Мay-11 & Jun-11 \\
\hline Benin & 515 & 555 & 575 & 575 & 540 & 555 & 575 & 575 \\
\hline Burkina Faso & 682 & 682 & 682 & 682 & 606 & 606 & 606 & 606 \\
\hline Côte d'Ivoire & 774 & 774 & 774 & n.a. & 544 & 544 & 615 & n.a. \\
\hline Guinea-Bis sau & 662 & 662 & n.a & n.a & 571 & 571 & n.a & n.a \\
\hline Mali & 680 & 680 & n.a & n.a & 600 & 600 & n.a & n.a \\
\hline Niger & 506 & 561 & n.a & n.a & 550 & 580 & n.a & n.a \\
\hline Senegal & 735 & 755 & n.a & n.a & 665 & 691 & n.a & n.a \\
\hline Togo & 560 & 540 & 540 & 567 & 555 & 570 & 570 & 599 \\
\hline Ghana & 405 & 502 & 445 & 450 & 409 & 507 & 449 & 454 \\
\hline Nigeria & 414 & 415 & 447 & 435 & 424 & 431 & 458 & 465 \\
\hline
\end{tabular}

Source: Country authorities.

\footnotetext{
2 This cost estimate reflects the losses to the government of selling these products to distributors at fixed prices that are lower than the import price paid by the government, plus taxes and agreed margins for distributors.

${ }^{3}$ The smoothing formula limiting monthly increases to 5 percent will lead to continuing but declining subsidy costs in 2011. Without any price adjustment, the cost would have reached an estimated 1.9 percent of GDP for JuneDecember 2011. All estimates assume roughly unchanged global prices for oil.
} 
6. These revisions to the $\mathbf{2 0 1 1}$ fiscal framework are intended to address concerns for both fiscal sustainability and the social impact of the fuel price shocks. Revenue projections and other spending plans in 2011 remain appropriate, and the authorities have revised quarterly quantitative indicative targets through end-2011 to reflect the changes discussed above (LoI, Table 1). While the net impact involves a minor fiscal relaxation relative the initial budget, ${ }^{4}$ the cumulative balances for 2008-2011 have remained consistent with the program's prudent target of a domestic primary balance near zero, particularly given last year's strong overperformance. ${ }^{5}$

\section{Mixed Progress in Structural Reforms}

7. The structural reforms planned under the ECF-supported program have generally continued to advance satisfactorily, albeit with delays in some important areas (Text Tables 2 and 3; LoI, ๆ20-29).

- The authorities improved public financial management by establishing the framework for a treasury cash management committee in December 2010 (meeting an end-January 2011 structural benchmark early), which has begun meeting. Concerning a strategy for a single treasury account, the authorities decided to initiate a consultative process with line ministries, development partners and technical advisors to elaborate a strategy to this end (as a result, the end-March benchmark was missed). The authorities remain committed to meeting the objective in this benchmark and expect to establish a new timetable following technical assistance from FAD.

- The authorities have also started to address the sustainability of the pension system by completing a financial and organizational audit of the public sector workers' pension fund and beginning an actuarial study of this institution (meeting an end-December benchmark).

- The adoption of a roadmap for the establishment of a one-stop window at the Port is advancing, following some delays. Technical difficulties in recruiting advisors for the roadmap were resolved in April (completing the measure for an end-September 2010 benchmark with a delay). As a result, the end-March 2011 benchmark for the adoption of the roadmap was missed. Work on the roadmap is underway, and the authorities remain committed to its adoption once it is finalized.

\footnotetext{
${ }^{4}$ The primary fiscal deficit will increase from 0.4 percent of GDP to 1.6 percent of GDP. The increase reflects an accommodation of the cost of social measures to accompany the increase in retail prices for petroleum products and the price subsidies during the application of the gradual price adjustment mechanism.

${ }^{5}$ The average domestic primary fiscal balance for $2008-2011$ is +0.15 percent of GDP. For reference, the DSA assumes an average domestic primary fiscal deficit of 0.3 percent of GDP for 2012-2031.
} 
- The pace of progress in the privatization process of state-owned banks-a structural cornerstone of the program-has fallen short of plans. A new public-private commission was set up under the new privatization law as part of a consultative process. The deliberations of this body have taken longer than initially expected. As a result, the authorities were unable to issue the final call for bids by end-April (structural benchmark). However, to demonstrate their determination to complete the process - one of the program's key objectives - the authorities have committed to initiate the tendering process by issuing a call for expressions of interest before the completion of the review (prior action). The authorities now expect to issue the final call for bids later this year.

- A mechanism to recover NPLs was also not set up in the planned timeframe, owing to the need to establish new legal and legislative authority. However, a decree to establish the mechanism formally is expected by the end of July 2011 (completing the measure for an endDecember benchmark with a delay).

Of the six structural benchmarks since the last review, the authorities met two, completed the measure for one with a delay, and have not completed the other three, despite progress. This mixed record is explained by continuing technical capacity constraints, as well as consultative and legal processes that—while desirable — are taking longer than expected.

\section{The completion of the ECF-supported program, with the conclusion of the sixth} review (as recommended by staff), allows for a preliminary assessment that it has largely achieved its objectives. The program's objectives at its outset in 2008 were to revive growth, improve living standards, and strengthen macroeconomic stability, by: (i) bringing public debt to a sustainable level through fiscal adjustment and HIPC/MDRI debt relief; (ii) facilitating the resumption of external assistance; (iii) increasing resources for infrastructure, health, and education; (iv) strengthening fiscal governance; (v) restructuring fragile banks; and (vi) reforming the business environment and state-owned enterprises. As discussed elsewhere, the general objectives of growth and macroeconomic stability have been achieved, despite numerous serious exogenous shocks. Per capita income has also risen modestly, reversing a downward trend during Togo's domestic crisis, but even faster sustained growth will be necessary to make substantial progress in living standards. The program fully achieved the first four specific objectives, although continued progress remains important, especially in the third and fourth objectives. Concerning the fifth and sixth objectives, significant financial restructuring of state-owned entities has been completed, yet concrete results in operational restructuring have fallen short of plans (for reasons discussed elsewhere). In particular, phosphate production has not yet recovered, and the bank privatization process-a cornerstone of the program - is running two years behind its original schedule - fortunately, the initiation of the tendering process shows tangible progress. Finally, the business environment has improved less than initially hoped. 
Text Table 2. Togo: Structural Conditionality for the ECF program in 2010

\begin{tabular}{|c|c|c|c|}
\hline Measures & Type & Date & Status \\
\hline \multicolumn{4}{|l|}{ Fiscal governance } \\
\hline $\begin{array}{l}\text { Complete implementation of the strategy } \\
\text { for clearing validated domestic arrears to } \\
\text { private suppliers. }\end{array}$ & Benchmark & end-March 2010 & $\begin{array}{l}\text { Not met. } \\
\text { Satisfactory } \\
\text { progress. }\end{array}$ \\
\hline $\begin{array}{l}\text { Move toward a single treasury account by } \\
\text { surveying treasury accounts in the } \\
\text { commercial banks and the BCEAO; } \\
\text { reduce the number of accounts by at } \\
\text { least } 30 \text { percent. }\end{array}$ & Benchmark & end-June 2010 & Met. \\
\hline $\begin{array}{l}\text { Simplify and reduce lag time in the public } \\
\text { sector expenditure chain by eliminating } \\
\text { redundant control points. }\end{array}$ & Benchmark & end-June 2010 & Met. \\
\hline \multicolumn{4}{|l|}{ Financial sector } \\
\hline $\begin{array}{l}\text { Advance on the privatization process for } \\
\text { state-owned banks by issuing a final call } \\
\text { for bids. }\end{array}$ & Benchmark & $\begin{array}{l}\text { end-September } \\
2010\end{array}$ & $\begin{array}{l}\text { Not met. } \\
\text { Postponed to } \\
\text { April } 2011 .\end{array}$ \\
\hline $\begin{array}{l}\text { Set up the nonperforming loan } \\
\text { management mechanism or structure and } \\
\text { its operational support. }\end{array}$ & Benchmark & $\begin{array}{l}\text { end-December } \\
2010\end{array}$ & $\begin{array}{l}\text { Not met. To be } \\
\text { done with a } \\
\text { delay. }\end{array}$ \\
\hline $\begin{array}{l}\text { Complete a financial and organizational } \\
\text { audit of the CRT and begin an actuarial } \\
\text { study of the institution. }\end{array}$ & Benchmark & $\begin{array}{l}\text { end-December } \\
2010\end{array}$ & Met. \\
\hline \multicolumn{4}{|l|}{ Real sector } \\
\hline $\begin{array}{l}\text { Recruit consultants to elaborate a report } \\
\text { on the required steps to create a one- } \\
\text { stop window at the Port Autonome de } \\
\text { Lomé. }\end{array}$ & Benchmark & $\begin{array}{l}\text { end-September } \\
2010\end{array}$ & $\begin{array}{l}\text { Not met. Done } \\
\text { with a delay. }\end{array}$ \\
\hline $\begin{array}{l}\text { Approve at the Council of Ministers a new } \\
\text { adjustment mechanism for petroleum } \\
\text { product prices. }\end{array}$ & Benchmark & $\begin{array}{l}\text { end-November } \\
2010\end{array}$ & Met. \\
\hline
\end{tabular}


Text Table 3. Togo: Structural Conditionality for the ECF Program in 2011

\begin{tabular}{|c|c|c|c|}
\hline Measures & Date & Macroeconomic Rationale & Status \\
\hline \multicolumn{4}{|l|}{ Fiscal governance } \\
\hline $\begin{array}{l}\text { Adopt the draft measures creating a } \\
\text { new institutional framework for treasury } \\
\text { cash management and putting this } \\
\text { framework into operation. }\end{array}$ & $\begin{array}{l}\text { Benchmark } \\
\text { end-January } \\
2011\end{array}$ & Strengthen treasury cash management. & Met. \\
\hline $\begin{array}{l}\text { Adopt a strategy that should lead over } \\
\text { time to the establishment of a single } \\
\text { treasury account after consultation with } \\
\text { the sectoral ministries and development } \\
\text { partners. }\end{array}$ & $\begin{array}{l}\text { Benchmark } \\
\text { end-March } \\
2011\end{array}$ & $\begin{array}{l}\text { Strengthen treasury cash management } \\
\text { to closely monitor Treasury operations. }\end{array}$ & $\begin{array}{l}\text { Not met. } \\
\text { Progress } \\
\text { ongoing. }\end{array}$ \\
\hline \multicolumn{4}{|l|}{ Financial sector } \\
\hline $\begin{array}{l}\text { Make progress in the privatization of } \\
\text { public banks by issuing a final call for } \\
\text { bids. }\end{array}$ & $\begin{array}{l}\text { Benchmark } \\
\text { end-April } 2011 \\
\text { (revised) }\end{array}$ & $\begin{array}{l}\text { Restore confidence in the Togolese } \\
\text { financial sector, reduce the risks of new } \\
\text { macroeconomic instability linked to the } \\
\text { large loss-making state-owned banks } \\
\text { and promote financial sector development } \\
\text { and the expansion of financial } \\
\text { intermediation. }\end{array}$ & $\begin{array}{l}\text { Not met. } \\
\text { Progress } \\
\text { ongoing. }\end{array}$ \\
\hline $\begin{array}{l}\text { Launch the process of calling for } \\
\text { expressions of interest for the state- } \\
\text { owned banks by publishing a pre- } \\
\text { qualification notice in the national press } \\
\text { in the form of an advertisement. }\end{array}$ & $\begin{array}{l}\text { Prior action for } \\
\text { completion of } \\
6^{\text {th }} \text { ECF review }\end{array}$ & $\begin{array}{l}\text { Restore confidence in the Togolese } \\
\text { financial sector, reduce the risks of new } \\
\text { macroeconomic instability linked to the } \\
\text { large loss-making state-owned banks } \\
\text { and promote financial sector development } \\
\text { and the expansion of financial } \\
\text { intermediation. }\end{array}$ & $\begin{array}{l}\text { Progress } \\
\text { ongoing. }\end{array}$ \\
\hline \multicolumn{4}{|l|}{ Real Sector } \\
\hline $\begin{array}{l}\text { Adopt in the Council of Ministers the } \\
\text { roadmap for the creation of a one-stop } \\
\text { window at the Port of Lomé and start } \\
\text { the implementation of first required } \\
\text { steps identified by the technical } \\
\text { consultants to achieve this objective. }\end{array}$ & $\begin{array}{l}\text { Benchmark } \\
\text { end-March } \\
2011\end{array}$ & $\begin{array}{l}\text { Foster Togo's competitiveness as a } \\
\text { regional commercial hub facilitate the } \\
\text { administrative procedures for exporting } \\
\text { and importing and contribute to increase } \\
\text { customs revenues. }\end{array}$ & $\begin{array}{l}\text { Not met. } \\
\text { Progress } \\
\text { ongoing. }\end{array}$ \\
\hline
\end{tabular}

\section{Article IV Discussions: BuILding Growth Momentum}

\section{A. Strengthening the Foundations for Medium Term Growth}

\section{Article IV discussions centered on policies to build growth momentum in the} medium-to-long term, while consolidating hard-won macroeconomic stability. At the time of the last Article IV consultation in early 2009, medium-term economic growth was expected to average about 1.6 percent, in the face of the effects of the global financial crisis and price shocks. In fact, annual growth averaged 3.1 percent for 2008-2010, because the authorities pursued an appropriate countercyclical fiscal policy and the external environment had a less negative effect than expected. Structural reforms have proven more challenging, however, because of limited administrative capacity and the challenges of building political and social consensus for reforms through legislative and consultative processes (Box 3). 


\section{Box 3. Togo: Response to Fund Advice in the 2009 Article IV Discussions}

Togo has had a productive policy dialogue and program relationship with the IMF. The country's policies have been generally consistent with the conclusions of the 2009 Article IV discussions and Fund policy advice, as reflected in the timely completion of the ECF reviews with relatively few waivers, and the rapid achievement of the HIPC completion point after the decision point. Authorities and staff agree on the main bottlenecks to growth.

Togo strengthened public finances while increasing investment and social spending under the program. It made progress in public financial management and budget execution, while its debt position improved dramatically thanks to external debt relief related to the HIPC initiative and prudent fiscal policy.

Reform of state-owned enterprises, state-owned banks and the business climate has advanced, although not as much as initially hoped. In retrospect, original reform timelines-e.g., for bank privatization, restructuring of the phosphate sector and improvement of the business climate-were too ambitious, given administrative capacity constraints, the need to update legislative frameworks, the time required by new consultative processes and the challenge of building consensus. The authorities are committed to maintain or even accelerate progress in these priority areas.

10. The authorities see their main challenge as building on the macroeconomic stabilization and growth achieved under their program to achieve robust, sustained growth. The foundations for sustained growth - particularly physical, human and social capitalseriously deteriorated during nearly 15 years of political crisis and international isolation. At the same time, progress in meeting social needs stagnated or reversed, as reflected in the mixed record in moving toward the MDGs (Table 10). The quality, as well as the pace, of growth will be important in meeting these needs, which will require continued progress in boosting social spending and fostering growth in sectors like agriculture in which gains are relatively well distributed.

\section{To improve social outcomes in the medium term, the authorities intend to devote} much of the available fiscal space towards social expenditures. The authorities are in the process of preparing their next Poverty Reduction Strategy Paper, and they understandably consider that the infrastructure gap remains a critical bottleneck to sustained growth and poverty reduction (see below). At the same time, they aim to enhance their capacity to distribute the fruits from higher growth more widely, increasing resources devoted to social objectives while striving to match outcomes to available resources. To reconcile these social objectives with fiscal sustainability, the authorities and staff shared the view that it was vital to improve social services 
for the population in cost-effective ways, especially the most vulnerable (Box 4). To assist in targeting, the authorities have started preparing a new poverty survey, with help from the World Bank, in preparation for the next Poverty Reduction Strategy. In this context, the authorities and staff also stressed that it is important to develop a productive and affordable civil service to help meet social needs and address administrative capacity constraints.

\section{To address infrastructure bottlenecks, the authorities aim to scale up public investment while maintaining macroeconomic stability and debt sustainability. The} authorities' medium-term macroeconomic framework incorporates a moderate scaling up of $2 \frac{1}{2}$ percent of GDP per year in 2012-2014 (Figure 3). As currently envisioned, the financing of the scaling up would rely practically entirely on external grants and concessional borrowing, supplemented by regional local currency borrowing as necessary. Staff supports this strategy in principle, provided it remains consistent with debt sustainability, macroeconomic stability, and an appropriate financing strategy; the risks to sustainability of inefficient public investment require continuing vigilance and capacity building for the implementation of the scaling up. Fiscal and current account deficits would temporarily be higher, before returning to levels sustainable over the long run from 2015 onward. Although scaling up investment is an appropriate use of the room to borrow provided by external debt relief, the increase in public investment is expected to lead to some crowding-out in 2012-2014 (Table 5), following which private investment is expected to recover with fiscal consolidation in the medium term. In the medium-term, growth is expected to pick up with the scaling up and then fall back with the ensuing fiscal consolidation. Inflation is projected to revert to its long-term trend by 2012 as pressures from global price shocks ease. Structural reform efforts to enhance growth would also continue. Long-term growth is projected at 4.2 percent, based on trends in output in key sectors; however, there are significant upside risks, depending the return on scaled up public investment, as well as the impact and pace of structural reforms.

\section{B. Sustainable Growth-Promoting Fiscal Policies}

\section{The authorities recognize that the planned investment scaling up needs to be} accompanied by policies that ensure debt sustainability and high quality spending. Staff stressed and the authorities acknowledged that the scaling up should be limited in time and followed by a consolidation to return fiscal balances to levels sustainable over the long run (Figure 3). The updated DSA (Appendix II), discussed with the authorities, indicates that this moderate, temporary scaling up does not raise the rating for risk of debt distress. The fiscal space available for investment also depends critically on mobilizing domestic revenue, controlling the growth of current spending, and carefully managing significant public sector liabilities, particularly those to pensioners and pension funds. On the revenue side, deeper tax administration and custom reform, supported by the stricter control of exemptions, would mobilize more domestic resources for priority spending. For the medium term, the authorities intend to work with an upcoming FAD mission to update their reform strategy. 
Figure 3. Togo: Medium-Term Projections, 2009-16
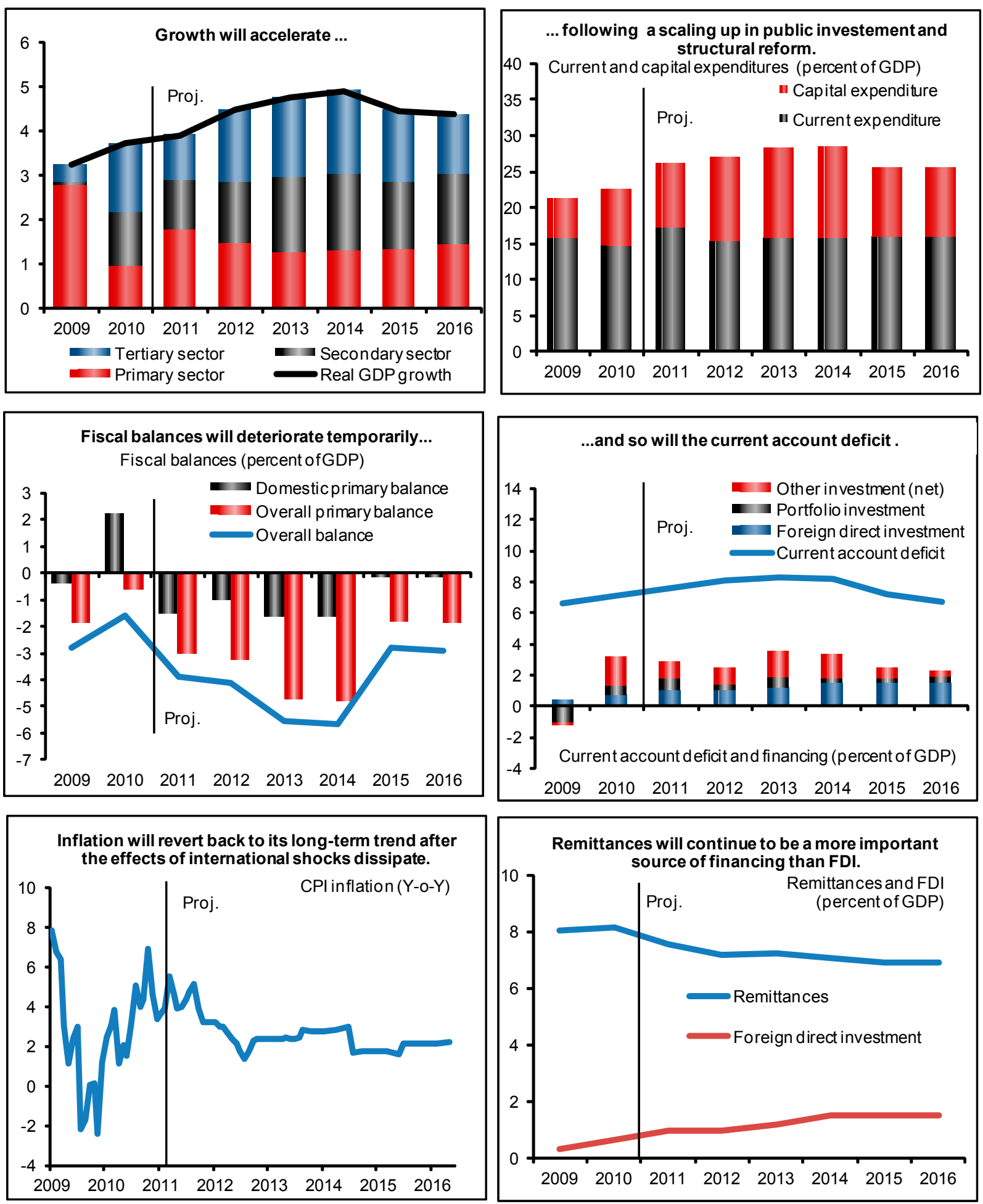

Source: Togolese authorities and fund staff estimates and projections. 


\section{Box 4. Togo: Establishing a Social Protection and Safety Net System}

Social needs are very high in Togo, especially given the economic stagnation during the long political crisis and suspension of international aid. According to the latest survey on poverty in 2006, 62 percent of the Togolese population lives below the poverty threshold (based on minimum caloric intake) and 82 percent are in a vulnerable situation, meaning that they have a high probability to remain poor or to become poor.

Recognizing this, authorities have budgeted higher social spending under the ECF-supported program, especially in the key sectors of education and health. The domestically financed social expenditures are projected to increase from 5.4 percent of GDP in 2008 to 6.5 percent of GDP in 2011, a 44 percent increase in nominal terms. Over the same period, total social spending (domestic and externally financed) nearly doubled. Efforts involving the authorities, Fund staff, and donors are underway to refine it in order to allow better targeting and tracking.

Social needs are expected to become even more acute in 2011 due to the impact of the global oil price surge. The authorities are implementing temporary, targeted accompanying social measures for 2011, including a travel allowance for the lowest-paid wage earners. The development of these measures highlighted, however, the lack of mechanisms to target the poorest segments of the population in the informal sector and rural areas. The Togolese population remains vulnerable to further price surges - according to preliminary estimates, further increases of around 45 percent in global fuel and food prices will increase the poverty rate by about $4 \frac{1}{2}$ percent.

The authorities and partners are studying how to build more permanent, targeted and costeffective delivery mechanisms for social needs. A working group chaired by the authorities has brought together experts from the World Bank and UN agencies (ILO, UNDP, UNICEF, WFP, and WHO) to develop a national strategy for social protection, capable of specific targeting of the most vulnerable groups. The preliminary results of a study led by the World Bank suggest that existing social safety net spending (mostly cash transfers and food programs), besides price subsidies, represented only $1 / 2$ percent of GDP annually during 2008-10. Fund staff have participated in discussions with the group and have also intensified bilateral dialogue with participating agencies, especially the World Bank, UNICEF and the ILO. In particular, the authorities are studying the establishment of a health insurance system for civil servants, with the support of ILO, which could later be extended to the formal private sector and the informal sector.

\section{Staff and the authorities discussed an updated debt sustainability analysis that showed the revised medium-term macroeconomic framework did not raise the rating for risk of debt distress. The DSA indicates that Togo remains at moderate risk of debt distress. ${ }^{6}$}

\footnotetext{
${ }^{6}$ The authorities are negotiating with a number of bilateral (non-Paris Club), multilateral and commercial creditors to reach agreement on the provision of debt relief on terms comparable to the relief accorded in the context of the HIPC initiative in December 2010.
} 
Togo's external and public debt indicators are projected to remain below the relevant thresholds under prudent baseline assumptions. However, Togo's debt outlook remains vulnerable to shocks, particularly if growth falls short of the baseline assumption or new financing is obtained on less favorable terms. These dynamics emphasize the importance of the authorities maintaining a prudent approach to new borrowing and maximizing the amount of external financing on grant or concessional terms, as well as pursuing reforms to improve debt management capacity. The Togolese authorities concurred with the DSA and its policy implications and expressed strong interest in the consequences for the country's risk rating for limits on external borrowing in the context of a future Fund-supported program.

\section{To inform the policy dialogue on sustainable scaling up, staff applied a dynamic} general equilibrium model of debt sustainability on a pilot basis to investigate the growthpublic investment nexus in Togo (Appendix III). ${ }^{7}$ The model suggests that a larger investment surge could promote growth without jeopardizing debt sustainability, under certain conditions that would nevertheless require continued strong reform efforts. These conditions include enhancing the efficiency and quality of public investment to a level typical of a sub-Saharan African country, implementing a sustainable debt management strategy, and increasing revenue collection (which might require an increase in tax rates if improvements in the efficiency of revenue collection were not sufficient).

\section{The authorities found that the} application of the model to Togo provided a useful analytical framework for considering medium-term policy

alternatives. The authorities believe - and staff agreed - that Togo is a particularly appropriate candidate for this analysis and scaling up in general. The authorities highlighted that infrastructure needs had long been neglected and that the debt relief under the HIPC initiative and strengthened public financial management achieved under


the ECF-supported program created a favorable context for scaling up. Staff stressed the need to ensure robust fiscal sustainability and to continue improvements in public financial management, especially project selection and execution, since Togo has had a relatively low public investment management capacity (Text Figure 5). The latter's importance is reinforced by the role of assumptions on the rate of return of investments in determining the economic outcome of a surge

\footnotetext{
${ }^{7}$ The model simulates an investment surge larger than the 2012-2014 scaling up currently reflected in the macroeconomic framework. The model was developed by the IMF's Research and Strategy, Policy and Review departments, and its application to Togo is a collaborative effort between those departments and the African department.
} 
in public investment (Appendix III). The authorities concurred with staff and identified as priorities mobilizing more revenue (preferably by improving the efficiency of tax collection rather than resorting to higher rates) and accelerating ongoing reforms in public financial management. The authorities intend to explore ways to apply this analytical tool, jointly with staff, to quantify the impact of alternative policy options, in parallel with other tools (e.g., DSA).

\section{Staff suggested to the authorities that in the medium-term, fiscal policy could} benefit from anchoring public expectations and debate with a more formal policy rule (Appendix IV). Given the authorities' objectives of scaling up infrastructure spending while maintaining debt sustainability, staff argued in favor of adopting a formal rule-based framework with dual anchors for the fiscal deficit and debt level. ${ }^{8} \mathrm{~A}$ debt target would be set at a level consistent with Togo's institutional and administrative development. The anchors should also allow for flexibility in responding to shocks, e.g., transparently and temporarily deviating from the target. The authorities and staff agreed that a key ingredient to the success of a rule-based framework - possibly in a simplified Fiscal Responsibility Law—is ownership. It is thus important to build a consensus among all stakeholders following a public debate. While recognizing the value of fiscal policy rules, the authorities noted that the importance of discussing this issue at the WAEMU level.

\section{Given plans to finance growing public investment, it is increasingly important to} develop a comprehensive debt management strategy guided by best practices. Debt management improved in a number of areas, including debt service projections, analytical capacity at the public debt management unit, the elaboration of a basic debt strategy, and better coordination among the different entities involved in debt management-although coordination needs further improvement. However, the debt management strategy currently prepared with the annual budget focuses only on external debt, does not assess the costs and risks of the existing portfolio, and does not consider alternative options based on clearly defined portfolio management objectives. The authorities concurred that a comprehensive, forward-looking debt management strategy is an integral part of a sound fiscal policy, and they intend address the current strategy's shortcomings, with the support of the IMF, through AFRITAC West, and the World Bank.

\section{Strengthening Pro-Growth Structural Policies}

19. Togo remains committed to addressing numerous, persistent structural weaknesses that constrain its growth potential and competitiveness. These weaknesses are generally a legacy of the political crisis and the suspension of international cooperation, during which key sectors of the economy deteriorated significantly. Growth and export performance have suffered

\footnotetext{
${ }^{8}$ Deficit and debt targets would also need to be designed and implemented in a way that takes into account the purposes of the financing. Since investment spending builds assets and fosters growth, it has different implications for the sustainable level of fiscal deficits than current spending.
} 
(Text Figure 4 and Box 5), despite a significant devaluation in 1994. Structural reforms to address these weaknesses and boost productivity growth will improve both growth performance and competitiveness.

20. Although Togo's real effective exchange rate has appreciated in the last decade, standard analysis reveals no evidence that the exchange rate is currently overvalued (Box 5). The authorities focused discussion on the main drivers of the real effective exchange rate.

\section{Box 5. Togo: ExChange RATE ASSESSMENT AND NON-PRiCe CoMPETITIVENESS}

The exchange rate assessment finds that Togo's real effective exchange rate (REER) was broadly in line with economic fundamentals in 2010, highlighting the importance of measures to strengthen non-price competitiveness. Survey-based structural indicators suggest that addressing infrastructure bottlenecks and improving the business climate are crucial to unlocking the country's growth potential.

\section{EXCHANGE RATE ASSESSMENT}

The three CGER methods-fundamental equilibrium exchange rate (FEER), macroeconomic balance (MB) and external sustainability (ES) approaches—all suggest that the REER was broadly in line with fundamentals in 2010.

The FEER approach relates the equilibrium REER to a set of fundamental factors (terms of trade, productivity, public consumption and openness). It suggests that the REER was slightly below its equilibrium level in 2010 , by about 4.4 percent, as opposed to a 4.2 percent overvaluation in 2009. This result - mainly driven by the depreciation of the euro over 2010 - is consistent with the latest WAEMU exchange rate assessment, which finds an undervaluation of some -2.6 percent in 2010 , as opposed to an overvaluation of 6.2 percent in 2009.

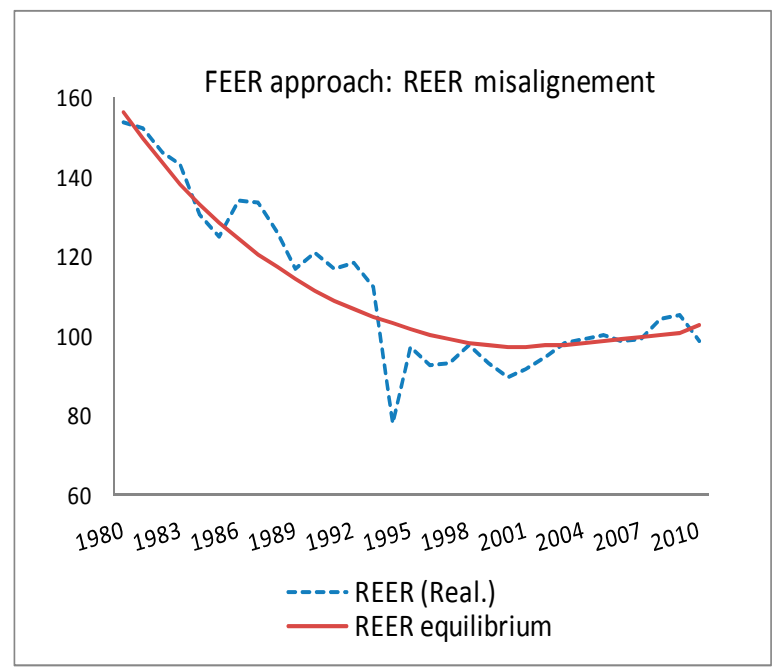

The MB approach estimates the REER adjustment needed to close the gap between the current account balance implied by macroeconomic fundamentals and the underlying current account balance-i.e., the medium-term current account balance stripped of all temporary factors. The analysis indicates that a 1.5 percent depreciation in the REER would be needed to close the gap, which is not a significant deviation from equilibrium.

The ES approach estimates the difference between the actual current account balance and the balance that would stabilize Togo's Net Foreign Asset position at some benchmark level. Our scenario, based on the average estimated NFA position during 2007-2009, yields an overvaluation of about 1.7 percent, again not a significant deviation from equilibrium. 
21. In this context in a regional currency union, the authorities and staff agreed that supply-side, structural reforms are the key to boosting the country's growth potential and competitiveness. Given that Togo has geographic advantages for serving as a regional commercial hub, non-price competitiveness will play role a vital role in fostering growth (Box 5). However, over the past five years Togo has not advanced much on its position in the Doing Business rankings, indicating that non-price competitiveness still has room for improvement (Figure 4). Staff agreed with the authorities' focus on investing in new infrastructure; staff also stressed the need to improve the quality and maintenance of existing infrastructure and to reduce its costs. The authorities place a high priority on improving the overall business climate, with assistance from the World Bank. Fund staff stressed the importance efforts to establish the one-stop window for all trade operations at the Port of Lomé, where the length of procedures reduces incentives for compliance. Also, as mentioned above, reforms have recently yielded disappointing productivity results in certain SOEs, particularly for phosphates, where production levels and cost structures have not yet improved as much as hoped, despite considerable investment in the past two years.

\section{Box 5. TOgo: EXChange Rate ASSESSMENT AND NON-PRICE COMPETITIVENESS (concluded)}

\section{NON-PRICE COMPETITIVENESS}

Although Togo's exports are rising in nominal terms, its share in the world and regional market has declined during the past few years - an indication of a possible loss in competitiveness. Togo exports' share in total world exports was relatively higher on average in the $1980 \mathrm{~s}$-reflecting international commodity prices - before falling to a lower level by the end of the 1990s, notwithstanding the 1994 devaluation. The country's share of the regional market dropped from an average of 12 percent during 2000-2004 to below 7 percent during 2005-2009 (Figure 4). Togo has diversified its export markets but has not made progress in product diversification. While Togo's export base remains fairly narrow as shown by the Herfindahl index of export diversification (Figure 4 ), it compares well with other WAEMU countries in recent years.

Weaknesses in the supply and quality of infrastructure developed during the domestic crisis, and its costs remain high for businesses (Figure 4). This tendency is particularly true in energy and telecommunications, which impose additional strains on local businesses. For instance, value lost because of power outages amounted to more than 10 percent of total sales in 2009, well above the average for sub-Saharan Africa of around 6 percent. Recent efforts to ensure energy security, such as bringing in a large independent power producer, are likely to limit future power disruptions, but production costs have not yet been reduced. Generally, staff emphasized that telephony and internet costs are high compared to other countries in the region, where competition and private sector involvement in the sectors are greater.

Togo has made limited progress in the Doing Business Indicators over the past few years (Figure 4). Although Togo is roughly comparable to the average ranking of other WAEMU countries, it lags significantly behind Rwanda - a comparable post-crisis country - in all but two indicators: "closing a business" and "trading across the border" (Figure 4). Given Togo's vocation to serve as a commercial hub, the authorities rightly aim to provide a business climate that is more hospitable than many of its regional peers. 
Figure 4. Togo: Non-price Competitiveness
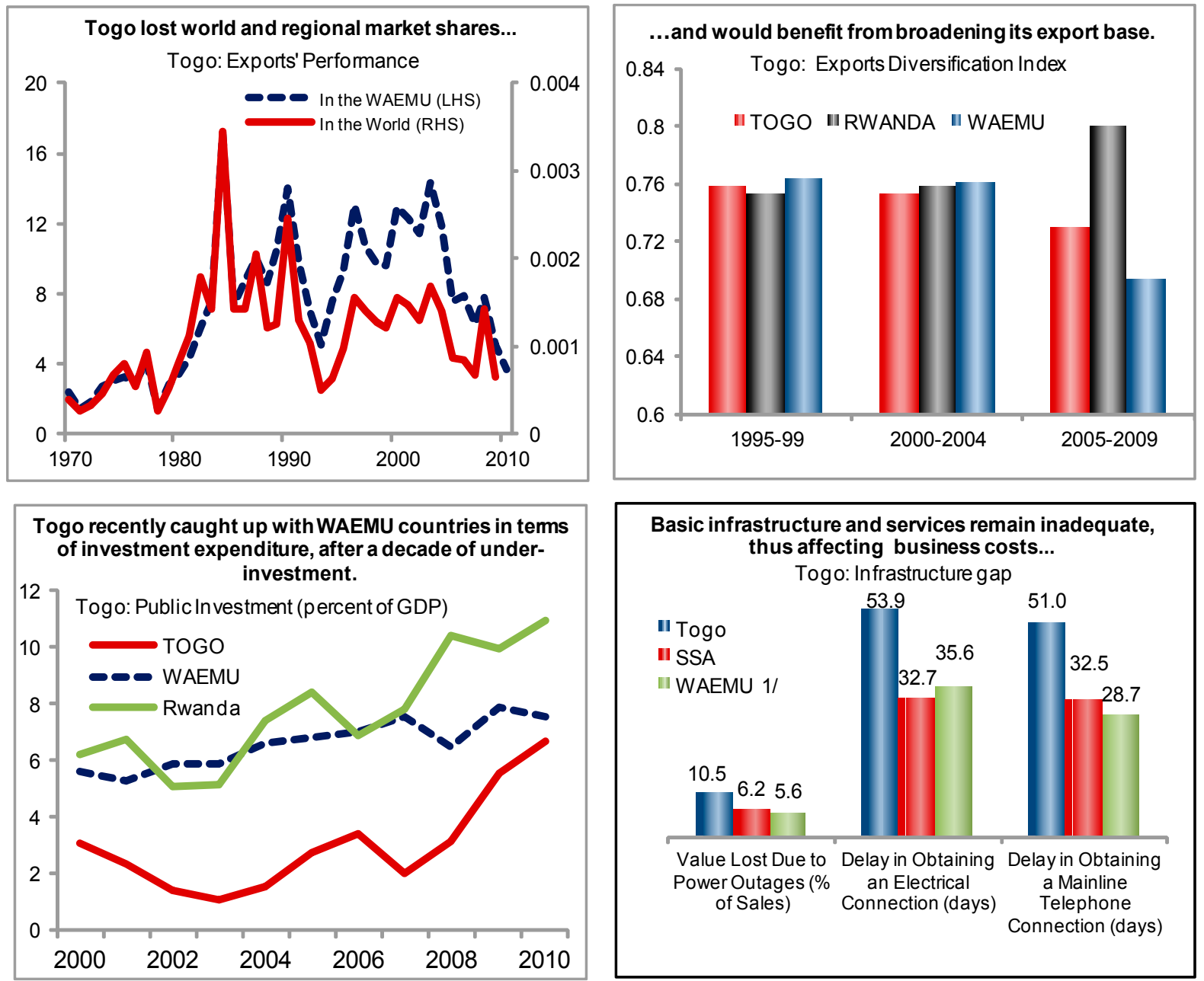

While Togo compares well to WAEMU peers in Doing Business indicators, it lags behind Rwanda...
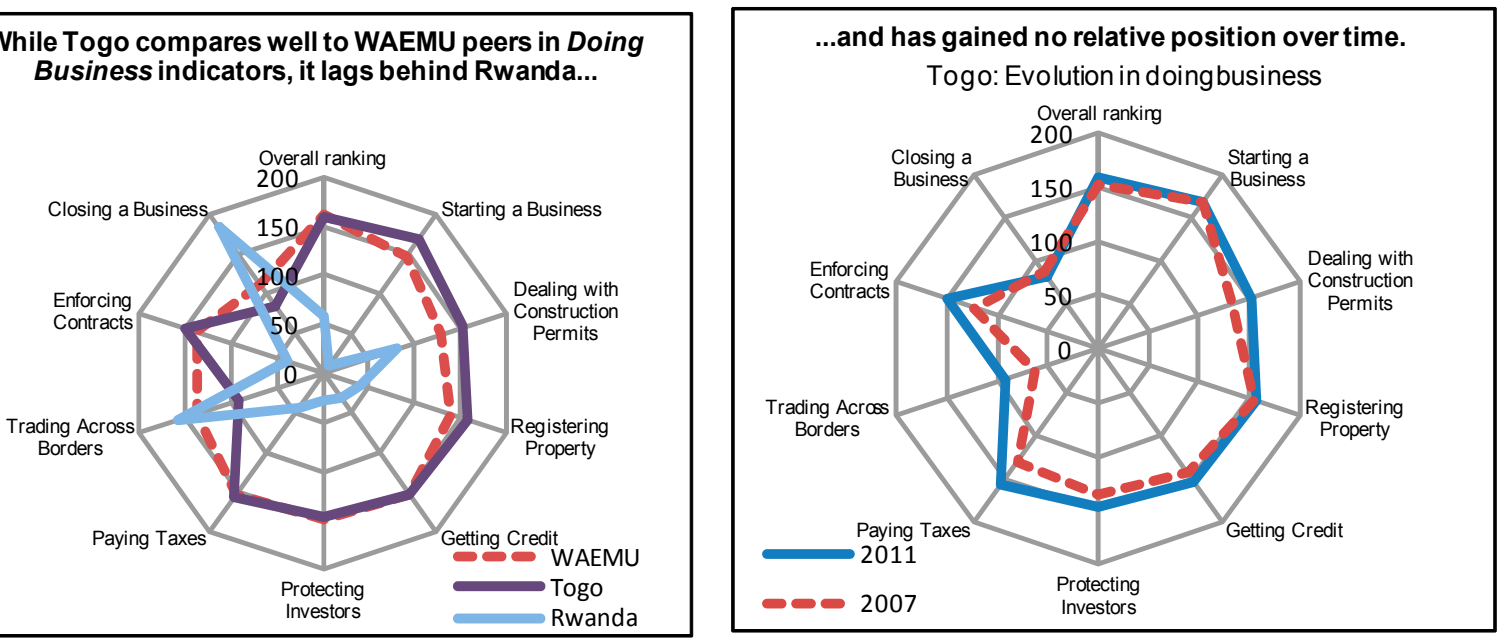

Sources: Togolese auth orities and fund staff estimates, World Bank/IFC Doing Business database, World Bank/IFC Enterprise Surveys and UNCTADstat database.

1/ Surveys were conducted in differentyears: Guinea-Bissau (2006); Senegal (2007); Ben in, Burkina Faso, Côte D'ivoire, Niger and Togo (2009); Mali (2010) 
22. The authorities recognize the central role of deeper financial sector development in fostering sustained robust growth. Enterprises in Togo identify access to credit as one of the biggest impediments to private sector development. ${ }^{9}$ Staff stressed two complementary points:

(i) that completing the operational restructuring of the banking sector-through the privatization process - is a crucial and pressing step for the financial sector development agenda; and (ii) that fostering financial intermediation while maintaining financial soundness requires addressing the current structural problems confronted by the sector (Box 6). The authorities broadly agreed and have therefore initiated work on a financial sector development strategy, with broad stakeholder participation and support from the IMF, the World Bank and other development partners. The strategy will develop detailed policy recommendations to address the barriers to development for the sector. In addition, staff encouraged the authorities to develop a strategy to address deficiencies identified in Togo's recent mutual evaluation report on anti money-laundering and combating the financing of terrorism (AML/CFT).

\section{RELATIONS WITH THE IMF}

\section{The authorities consider IMF support of their economic program an important} element in its success, and in their Letter of Intent, they request the opening of discussions on a successor IMF-supported economic program. The expiration of the current ECF provides an opportunity for the authorities and staff to reflect on the lessons from the current program before launching discussions on a successor arrangement. In particular, the authorities and staff agreed that a public seminar in Togo would provide a useful opportunity to discuss these issues with the broad participation of domestic and external stakeholders. Public dialogue would enhance ownership of a successor program. The authorities also emphasized that financing needs will remain substantial over the medium-term, given large needs for social and physical infrastructure. They have also appreciated the contribution of ongoing policy dialogue and technical assistance to policy development and policy-making capacity.

\section{Staff Appraisal}

24. The program has broadly achieved its objectives for growth and macroeconomic stability in 2010. Notwithstanding numerous external shocks over the past three years-global recession, flooding, two rounds of global oil and food price shocks, and regional political instability - macroeconomic stability has steadily strengthened and economic growth has begun recovering gradually. Budget execution was strong in 2010, and all performance criteria were met by ample margins. Investment and social spending execution improved, signaling that public expenditure management reforms under the program are beginning to bear fruit.

\footnotetext{
9 The World Bank's Diagnostic Trade Integration Study, September 2010.
} 
Box 6. Togo: Developments in the Banking Sector

The performance of the banking sector in Togo is gradually recovering, following the recapitalization process undertaken at end-2008. Overall, the capacity of Togolese banks to play their role in financial intermediation has improved, as shown by a recent pick-up in growth in credit to the private sector and improvements in aggregate financial soundness indicators (Box 6 Table).

However, some banks continue to present certain vulnerabilities. As of December 2010, four out of 11 banks did not meet the new minimum capital requirements of CFAF 5 billion (about \$10 million), and two banks did not meet the required capital asset ratio of 8 percent (although the larger of these banks had a ratio of 7.5 percent, close to the regulatory requirement). The paucity of qualified risk management personnel continues to be a source of risks. However, profitability in the sector has recovered from the low levels observed in 2008 and 2009, which helps reduce the risk that new financial support by the state may be needed.

Box 6 Table. Togo: Selected Financial Soundness Indicators

\begin{tabular}{|c|c|c|c|c|c|c|}
\hline & Sep-08 & Dec-08 & Dec-09 & Jun-10 & Dec-10 & Mar-11 \\
\hline Capital Asset Ratios & \multicolumn{6}{|c|}{ (in \%) } \\
\hline Capital to Risk Weighted Assets & -4.1 & 13.4 & 12.0 & 14.0 & 14.4 & 13.8 \\
\hline \multicolumn{7}{|l|}{ Quality of Asset Portfolio } \\
\hline NPLs as a \% of Gross Loans & 25.4 & 14.3 & 14.6 & 15.1 & 13.7 & 14.2 \\
\hline \multicolumn{7}{|l|}{ Profitability } \\
\hline Return on Assets & $\ldots$ & -0.7 & 0.7 & 1.0 & 1.7 & $\ldots$ \\
\hline Return on Equity & $\ldots$ & -7.2 & 7.1 & 13.4 & 20.0 & $\ldots$ \\
\hline Interest Margins over Gross Revenue & $\ldots$ & 64.7 & 60.9 & $\ldots$ & $\ldots$ & $\ldots$ \\
\hline Non-Interest Expenditures over Gross Revenue & $\ldots$ & 48.1 & 40.9 & $\ldots$ & $\ldots$ & $\ldots$ \\
\hline \multicolumn{7}{|l|}{ Liquidity } \\
\hline Liquid Assets over Total Assets & 47.9 & 50.2 & 42.5 & 42.4 & 42.2 & 46.2 \\
\hline Share of Government Securities on Total Liquid Assets & 9.2 & 8.1 & 40.0 & 37.1 & 33.5 & 31.4 \\
\hline Ratio of Foreign Currency Denominated Liabilities over Total Liabilities & 2.7 & 1.8 & 1.4 & 9.2 & 10.7 & 2.0 \\
\hline
\end{tabular}

Source: BCEAO and IMF Staff calculations.

Although credit growth has recovered, intermediation efficiency remains low and interest rate spreads have been persistently high, largely reflecting a risky business environment (Box 6 Figure). The resumption in credit growth observed in 2009 and 2010 was relatively evenly distributed across sectors and has not yet been accompanied by an increase in NPL ratios. The high interest rate spreads observed in Togo could be linked to several factors, such as macroeconomic risks, high overhead costs, weak institutions to protect creditor's rights, and inadequate bankruptcy procedures, among others. Institutional weaknesses are also reflected in the extremely high collateral requirements, even compared to other countries in the region. 

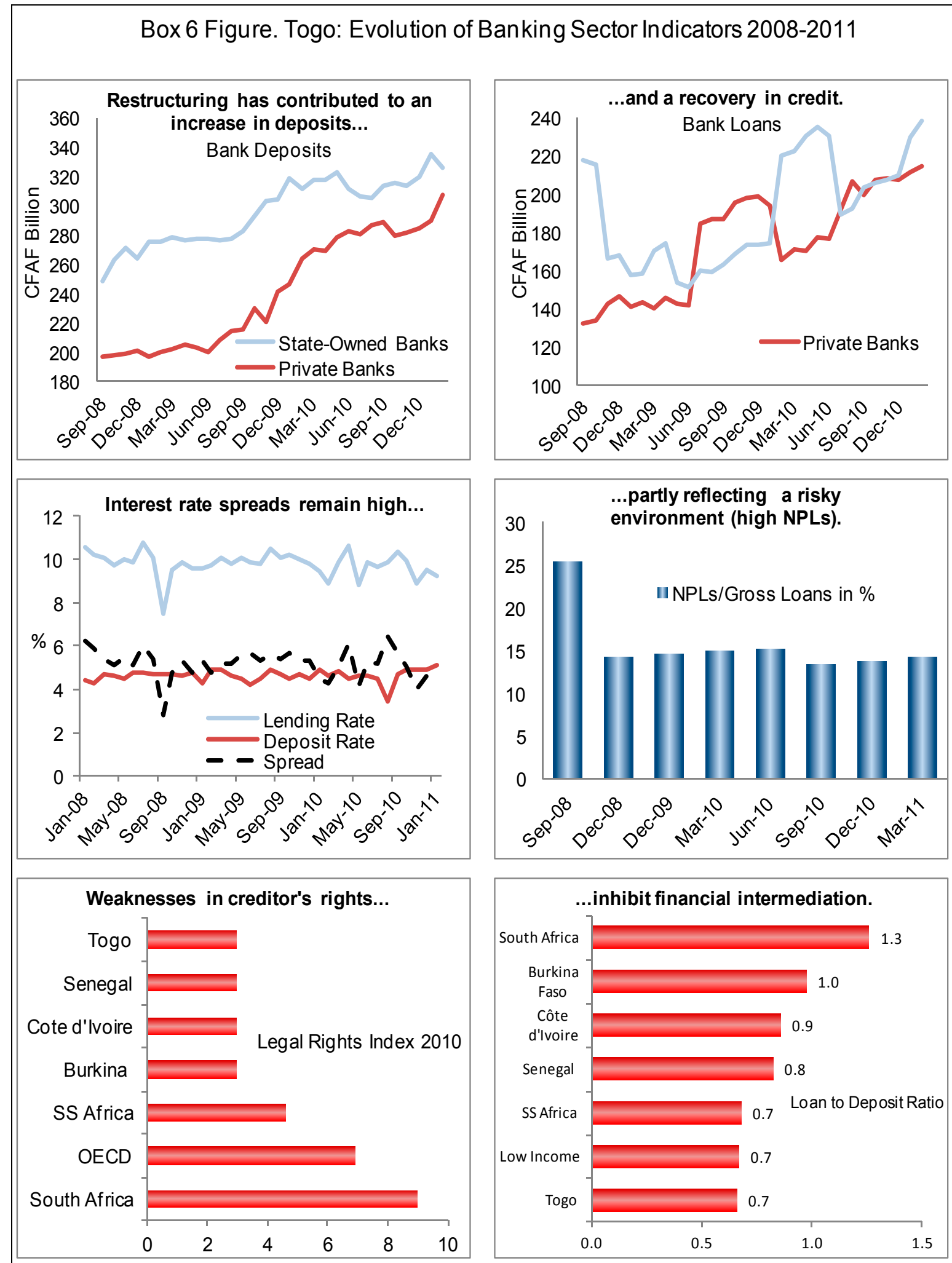

Source: BCEAO, World Bank/IFC Doing Business Database, World Bank Financial Structure Database and Fund Staff Calculations. 
25. The improving economic performance and sound policies generally continued in early 2011, despite the impact of the global oil price shock, particularly on fiscal policy. Committed to maintaining a sustainable fiscal framework, the authorities are undertaking appropriate additional fiscal measures in 2011, including beyond the program period. Concerned with social stability, the authorities initially did not pass through the global oil price shock to consumers, which led to a poorly targeted general price subsidy and mounting fiscal costs. Recognizing these pressures, the authorities took corrective actions by beginning to implement a previously adopted automatic price adjustment mechanism, with a smoothing formula, and by partially offsetting the costs incurred with spending savings from elsewhere in the budget. Partially offsetting the cost with spending savings helped protect fiscal sustainability, but the quality of the adjustment was low, since the subsidy cost was offset by a reduction in more productive investment spending. To cushion the social impact of higher prices, the authorities also appropriately developed temporary, targeted social measures through a consultative process.

26. The authorities have continued to make progress in key structural reforms under the IMF-supported program, although some delays have developed in 2011, including in important financial sector reforms. Delays have largely reflected administrative capacity constraints and lengthier than expected legislative and consultative processes. The authorities remain committed to completing the measures in the benchmarks, and in particular, they plan to initiate the tendering process for the privatization of state-owned banks, a cornerstone of their structural reforms.

27. Staff recommends completion of the sixth review of the PRGF arrangement, on the basis of the performance and assessment discussed above.

28. The Article IV consultation discussions focused on fiscal and structural policies to achieve higher economic growth while maintaining stability. The proposed temporary scaling up of public investment in the medium-term economic framework can support growth without compromising stability under the authorities' current policy plans. It is important to maintain the current financing strategy, including on concessionality, as well as revenue and spending plans. The authorities' ongoing efforts to improve public expenditure management, public investment capacity, and revenue collection give cause for optimism; further success may create the conditions in which the authorities could scale up investment further, without jeopardizing sustainability. Stronger public finances have yielded significant and broad benefits in terms of enhanced economic confidence; care should be taken to preserve these hard-won gains.

29. Growth performance would benefit from a faster pace of structural reform. The priority sectors are banking, phosphate, telecommunications and energy, where state-owned enterprises play large roles. In particular, the contribution of the financial sector to growth ought to be enhanced, for which bank privatization will be key. Administrative capacity constraints have proven an obstacle to reform implementation, highlighting the relationship between growth and public sector reform. 
30. Deeper structural reforms also offer the best means to enhance Togo's competitiveness. The real effective exchange rate is in line with fundamentals, according to studies. Membership in the WAEMU currency zone continues to serve Togo's economic interests, providing a valuable anchor for stability.

31. It is proposed that the next Article IV consultation with Togo takes place within 24 months, subject to the decision on consultation cycles (Decision No. 14747 - (10/96), September 28, 2010). 
Table 1. Togo: Selected Economic and Financial Indicators, 2009-13

\begin{tabular}{|c|c|c|c|c|c|c|c|c|}
\hline & \multirow{2}{*}{$\frac{2009}{\text { Actual }}$} & \multicolumn{2}{|c|}{2010} & \multicolumn{2}{|c|}{2011} & \multicolumn{2}{|c|}{2012} & \multirow{2}{*}{$\begin{array}{l}2013 \\
\text { Proj. }\end{array}$} \\
\hline & & 5th. Rev. & Est. & 5th. Rev. & Proj. & 5th. Rev. & Proj. & \\
\hline & \multicolumn{8}{|c|}{ (Percentage growth, unless otherwise indicated) } \\
\hline \multicolumn{9}{|l|}{ National income, prices, and exchange rates } \\
\hline Real GDP & 3.2 & 3.4 & 3.7 & 3.7 & 3.9 & 4.0 & 4.5 & 4.7 \\
\hline Real GDP per capita & 0.7 & 0.8 & 1.1 & 1.2 & 1.3 & 1.4 & 1.9 & 2.2 \\
\hline GDP deflator & 1.9 & 1.4 & 1.8 & 2.2 & 3.8 & 1.8 & 2.7 & 2.4 \\
\hline Consumer price index (average) & 1.9 & 2.2 & 1.4 & 2.0 & 4.3 & 1.8 & 2.6 & 2.4 \\
\hline GDP (CFAF billions) & 1,490 & 1,562 & 1,573 & 1,656 & 1,696 & 1,754 & 1,821 & 1,952 \\
\hline Exchange rate CFAF/US\$ (annual average level) & 470.7 & $\ldots$ & 494.2 & $\ldots$ & $\ldots$ & $\ldots$ & $\ldots$ & $\ldots$ \\
\hline Real effective exchange rate & 0.3 & $\ldots$ & -6.0 & $\ldots$ & $\ldots$ & $\ldots$ & $\ldots$ & $\ldots$ \\
\hline Terms of trade (deterioration $=-$ ) & 4.8 & 3.3 & -0.2 & -4.0 & -1.6 & -3.0 & -1.6 & -0.4 \\
\hline Monetary survey & \multicolumn{8}{|c|}{ (Annual change, percent of beginning-of-period broad money) } \\
\hline Net foreign assets ${ }^{1}$ & 0.7 & 3.0 & 3.0 & 3.6 & 2.1 & 3.9 & -0.2 & 0.8 \\
\hline Credit to government 1 & 6.4 & 4.0 & 3.0 & -1.0 & 4.8 & 0.2 & 1.4 & 1.9 \\
\hline Credit to nongovernment sector & 9.7 & 7.1 & 10.3 & 8.2 & 8.5 & 6.5 & 6.8 & 6.4 \\
\hline Broad money (M2) & 16.2 & 14.6 & 16.3 & 12.0 & 11.6 & 10.5 & 10.3 & 9.2 \\
\hline Velocity (GDP/end-of-period M2) & 2.4 & 2.2 & 2.2 & 2.1 & 2.1 & 2.0 & 2.1 & 2.0 \\
\hline & \multicolumn{8}{|c|}{ (Percent of GDP, unless otherwise indicated) } \\
\hline \multicolumn{9}{|l|}{ Investment and savings } \\
\hline Gross domestic investment & 18.0 & 16.7 & 18.9 & 20.2 & 19.4 & 20.5 & 21.8 & 22.7 \\
\hline Government & 5.5 & 6.7 & 7.9 & 9.8 & 8.9 & 10.0 & 11.5 & 12.6 \\
\hline Nongovernment & 12.5 & 10.0 & 11.0 & 10.3 & 10.5 & 10.5 & 10.3 & 10.1 \\
\hline Gross national savings & 11.4 & 9.0 & 11.7 & 12.8 & 11.7 & 13.6 & 13.7 & 14.4 \\
\hline Government & 2.7 & 3.9 & 6.2 & 7.2 & 5.0 & 7.6 & 7.4 & 7.0 \\
\hline Nongovernment & 8.7 & 5.1 & 5.4 & 5.6 & 6.8 & 6.0 & 6.4 & 7.3 \\
\hline \multicolumn{9}{|l|}{ Government budget } \\
\hline Total revenue and grants & 18.5 & 19.6 & 20.9 & 22.6 & 22.2 & 22.7 & 22.7 & 22.7 \\
\hline Revenue & 16.9 & 17.1 & 18.9 & 19.3 & 18.9 & 18.4 & 18.4 & 18.5 \\
\hline Total expenditure and net lending & 21.3 & 22.4 & 22.5 & 25.3 & 26.1 & 25.1 & 26.8 & 28.3 \\
\hline Domestic primary expenditure & 17.4 & 17.2 & 16.7 & 19.7 & 20.4 & 18.7 & 19.5 & 20.2 \\
\hline Overall balance (payment order basis) & -2.8 & -2.8 & -1.6 & -2.7 & -3.9 & -2.4 & -4.1 & -5.6 \\
\hline Domestic primary balance ${ }^{2}$ & -0.4 & -0.1 & 2.2 & -0.4 & -1.6 & -0.3 & -1.1 & -1.7 \\
\hline Change in domestic arrears & -1.0 & -3.0 & -2.3 & -0.8 & -0.8 & -0.3 & -0.3 & -0.3 \\
\hline \multicolumn{9}{|l|}{ External sector } \\
\hline Current account balance & -6.6 & -7.7 & -7.2 & -7.4 & -7.6 & -6.9 & -8.1 & -8.3 \\
\hline Exports (goods and services) ${ }^{3}$ & 36.8 & 34.1 & 37.3 & 33.2 & 37.4 & 33.3 & 37.1 & 37.2 \\
\hline Imports (goods and services) ${ }^{3}$ & -52.5 & -51.4 & -53.8 & -51.4 & -55.1 & -51.5 & -55.8 & -56.0 \\
\hline External public debt ${ }^{4}$ & 52.7 & 14.6 & 17.2 & 15.1 & 16.0 & 15.6 & 17.1 & 19.2 \\
\hline External public debt service (percent of exports) $)^{4}$ & 4.6 & 6.0 & 5.1 & 3.2 & 2.9 & 2.6 & 2.9 & 3.1 \\
\hline Total public debt ${ }^{4}$ & 67.8 & $\ldots$ & 32.3 & $\ldots$ & 27.4 & $\ldots$ & 27.1 & 27.8 \\
\hline
\end{tabular}

Sources: Togolese authorities and IMF staff estimates and projections.

${ }^{1}$ Change as a percentage of broad money at the beginning of the period.

${ }^{2}$ Revenue minus expenditure, excluding grants, interest, and foreign-financed expenditure.

${ }^{3}$ Aggregate import and export figures, both for historical data and for projections, now include separately the imports and exports from the binational electricity generating company $\mathrm{CEB}$, which were previously netted out when calculating aggregate numbers.

${ }^{4}$ Includes arrears and state-owned enterprises external debt. 
Table 2. Togo: Balance of Payments, 2009-13

\begin{tabular}{|c|c|c|c|c|c|}
\hline & 2009 & 2010 & 2011 & 2012 & \multirow{2}{*}{$\begin{array}{l}2013 \\
\text { Proj. }\end{array}$} \\
\hline & Actual & Prel. & Proj. & Proj. & \\
\hline & \multicolumn{5}{|c|}{ (Billions of CFA francs) } \\
\hline Current account balance & -99.1 & -112.7 & -129.7 & -146.9 & -162.7 \\
\hline Trade balance & -194.8 & -215.2 & -245.3 & -277.5 & -304.4 \\
\hline Exports & 426.2 & 439.2 & 470.2 & 501.5 & 538.6 \\
\hline Of which: Cotton & 7.7 & 7.6 & 18.5 & 16.4 & 16.7 \\
\hline Phosphates & 42.5 & 34.3 & 40.5 & 41.9 & 44.1 \\
\hline Cement \& clinker & 72.0 & 71.3 & 74.0 & 81.4 & 90.4 \\
\hline Reexports & 72.5 & 75.4 & 76.9 & 82.6 & 90.2 \\
\hline Imports, f.o.b. & -621.0 & -654.4 & -715.5 & -779.0 & -843.1 \\
\hline Of which: Imports for domestic use & -566.6 & -605.4 & -677.1 & -729.5 & -779.9 \\
\hline Of which: Petroleum products & -58.5 & -64.9 & -85.3 & -89.5 & -92.6 \\
\hline Services (net) & -38.3 & -44.4 & -54.7 & -61.6 & -64.0 \\
\hline Income (net) & -9.0 & -13.2 & -15.5 & -16.5 & -18.6 \\
\hline Current transfers (net) & 143.0 & 160.1 & 185.8 & 208.7 & 224.3 \\
\hline Of which: Remittances & 120.2 & 127.9 & 128.5 & 130.4 & 141.5 \\
\hline Capital and financial account & 1.0 & 63.7 & 62.4 & 63.1 & 88.3 \\
\hline Direct investment & 5.2 & 10.2 & 17.0 & 18.2 & 23.4 \\
\hline Portfolio investment, incl. bonds & -16.4 & 9.1 & 12.7 & 6.4 & 11.7 \\
\hline Other investment & -2.9 & 29.3 & 17.6 & 20.3 & 33.7 \\
\hline Errors and omissions & 8.6 & 12.9 & 0.0 & 0.0 & 0.0 \\
\hline Overall balance & -89.5 & -36.2 & -67.3 & -83.8 & -74.3 \\
\hline Financing & 89.5 & 36.2 & 67.3 & 83.8 & 74.3 \\
\hline Central bank net foreign assets ${ }^{1}$ & 25.9 & -31.7 & -13.4 & 3.5 & -6.0 \\
\hline Arrears, net change & 0.9 & 0.0 & 0.0 & 0.0 & 0.0 \\
\hline Principal & 1.2 & 0.0 & 0.0 & 0.0 & 0.0 \\
\hline Interest & -0.3 & 0.0 & 0.0 & 0.0 & 0.0 \\
\hline Flow rescheduling & 21.6 & 26.4 & 37.0 & 36.8 & 36.6 \\
\hline Clearance of debt/arrears & 4.7 & 677.2 & 0.0 & 0.0 & 0.0 \\
\hline Debt/arrears cancellation & -4.7 & -677.0 & 0.0 & 0.0 & 0.0 \\
\hline Debt and arrears rescheduling & 0.0 & 0.2 & 0.0 & 0.0 & 0.0 \\
\hline Exceptional financing & 41.0 & 41.1 & 43.7 & 0.0 & 0.0 \\
\hline Unidentified financing & 0.0 & 0.0 & 0.0 & 43.6 & 43.7 \\
\hline Memorandum items: & \multicolumn{5}{|c|}{ (Percent of GDP, unless otherwise indicated) } \\
\hline Current account balance & -6.6 & -7.2 & -7.6 & -8.1 & -8.3 \\
\hline Trade balance & -13.1 & -13.7 & -14.5 & -15.2 & -15.6 \\
\hline Exports of goods and services ${ }^{2}$ & 36.8 & 37.3 & 37.4 & 37.1 & 37.2 \\
\hline Imports of goods and services & -52.5 & -53.8 & -55.1 & -55.8 & -56.0 \\
\hline Gross international reserves (imputed in billions of USD) & 0.7 & 0.7 & 0.8 & 0.8 & 0.9 \\
\hline Gross international reserves (as a percentage of M2) & 51.6 & 49.2 & 45.7 & 41.1 & 44.7 \\
\hline Gross international reserves of the WAEMU (in billions of USD) & 13.2 & 12.9 & $\ldots$ & $\ldots$ & $\ldots$ \\
\hline Gross international reserves of the WAEMU (as a percentage of M2) & 69.3 & 57.9 & $\ldots$ & $\ldots$ & $\ldots$ \\
\hline Gross international reserves of the WAEMU (months of next year's imports) & 6.5 & 6.1 & $\ldots$ & $\ldots$ & $\ldots$ \\
\hline
\end{tabular}

Sources: Togolese authorities and IMF staff estimates and projections.

${ }^{1}$ Negative sign indicates increase. Includes SDR allocation in 2009.

${ }^{2}$ Aggregate import and export figures, both for historical data and for projections, now include separately the imports and exports from the bi-national electricity generating company $\mathrm{CEB}$, which were previously netted out when calculating aggregate numbers. Exports from $C E B$ accounted for about 3 percent of GDP in 2009 and imports of CEB for about 4.4 percent of GDP. 
Table 3a. Togo: Central Government Financial Operations, 2009-13

\begin{tabular}{|c|c|c|c|c|c|c|c|}
\hline & \multirow{2}{*}{$\begin{array}{l}2009 \\
\text { Act. }\end{array}$} & \multicolumn{2}{|c|}{2010} & \multicolumn{2}{|c|}{2011} & \multirow{2}{*}{$\begin{array}{l}2012 \\
\text { Proj. }\end{array}$} & \multirow{2}{*}{$\begin{array}{l}2013 \\
\text { Proj. }\end{array}$} \\
\hline & & 5th. Rev. & Act. & 5th. Rev. & Proj. & & \\
\hline & \multicolumn{7}{|c|}{ (In billions of CFA Francs) } \\
\hline Revenue and grants & 275.2 & 305.8 & 329.1 & 374.9 & 377.1 & 413.3 & 443.9 \\
\hline Total revenue & 252.4 & 267.6 & 296.9 & 320.2 & 319.8 & 335.0 & 361.1 \\
\hline Tax revenue & 229.0 & 234.8 & 246.6 & 269.2 & 268.8 & 299.7 & 323.0 \\
\hline Tax administration (DGI) & 105.7 & 105.8 & 113.4 & 118.5 & 118.1 & 130.9 & 141.1 \\
\hline Customs administration (DGD) & 123.3 & 129.0 & 133.2 & 150.7 & 150.7 & 168.8 & 181.9 \\
\hline Nontax revenue & 23.4 & 32.8 & 50.2 & 51.0 & 51.0 & 35.3 & 38.1 \\
\hline Grants (projects) & 22.8 & 38.3 & 32.2 & 54.7 & 57.3 & 78.3 & 82.8 \\
\hline Expenditure and net lending & 317.3 & 349.5 & 354.4 & 419.3 & 443.3 & 488.6 & 552.2 \\
\hline Of which: Dom. primary expenditures & 259.1 & 269.3 & 262.0 & 326.8 & 346.3 & 354.1 & 394.3 \\
\hline Of Which: temporary social measures & $\ldots$ & $\ldots$ & $\ldots$ & $\cdots$ & 3.4 & 0.0 & 0.0 \\
\hline Current expenditure & 235.0 & 244.3 & 230.8 & 256.2 & 292.5 & 279.2 & 306.3 \\
\hline Domestic primary current spending ${ }^{2}$ & 221.1 & 218.3 & 215.7 & 243.3 & 278.5 & 264.0 & 290.8 \\
\hline Wages and salaries & 94.2 & 91.8 & 82.6 & 97.5 & 98.7 & 111.1 & 119.1 \\
\hline Goods and services & 64.5 & 64.0 & 59.5 & 70.6 & 70.6 & 69.2 & 81.5 \\
\hline Transfers and subsidies & 59.2 & 62.6 & 69.4 & 75.2 & 109.2 & 80.8 & 87.2 \\
\hline Of which: Oil prices support & $\ldots$ & $\ldots$ & 3.7 & $\ldots$ & 31.8 & 0.0 & 0.0 \\
\hline Foreign-financed current spending ${ }^{3}$ & 0.0 & 11.1 & 0.0 & 0.0 & 0.0 & 0.0 & 0.0 \\
\hline Interest & 13.9 & 14.9 & 15.1 & 12.9 & 14.03 & 15.2 & 15.5 \\
\hline Domestic debt & 9.1 & 10.5 & 10.1 & 10.6 & 10.57 & 11.8 & 11.1 \\
\hline External debt & 4.8 & 4.3 & 5.0 & 2.3 & 3.46 & 3.5 & 4.4 \\
\hline Public investment & 82.3 & 105.2 & 123.6 & 163.1 & 150.7 & 209.4 & 245.9 \\
\hline Domestically financed & 37.9 & 51.0 & 46.2 & 83.6 & 67.7 & 90.1 & 103.5 \\
\hline Foreign financed ${ }^{3}$ & 44.4 & 54.2 & 77.3 & 79.5 & 83.0 & 119.3 & 142.5 \\
\hline Current balance & 17.4 & 23.3 & 66.1 & 64.0 & 27.3 & 55.8 & 54.8 \\
\hline Domestic primary balance & -6.7 & -1.8 & 34.9 & -6.6 & -26.5 & -19.1 & -33.2 \\
\hline Overall balance, payment order basis (incl. grants) & -42.1 & -43.7 & -25.3 & -44.4 & -66.2 & -75.3 & -108.4 \\
\hline Excluding grants & -64.9 & -82.0 & -57.5 & -99.1 & -123.5 & -153.6 & -191.1 \\
\hline Change in arrears ${ }^{4}$ & -15.6 & -46.8 & -36.9 & -13.2 & -13.2 & -5.5 & -5.9 \\
\hline Overall balance, cash basis (incl.grants; incl.change in arrears) & -58.9 & -90.5 & -62.2 & -57.6 & -79.4 & -80.8 & -114.2 \\
\hline Excluding grants & -80.5 & -128.8 & -94.4 & -112.3 & -136.7 & -159.1 & -197.0 \\
\hline Financing & 16.8 & 37.1 & 18.6 & 23.5 & 35.7 & 37.2 & 70.5 \\
\hline Domestic financing (net) & 14.0 & 26.4 & -10.6 & 1.8 & 13.0 & 1.8 & 17.6 \\
\hline Banking system & 14.7 & 24.5 & 5.4 & -6.8 & 34.7 & 10.9 & 16.4 \\
\hline Nonbank financing & -0.7 & 1.9 & -16.1 & 8.6 & -21.7 & -9.1 & 1.1 \\
\hline External financing (net) & 2.8 & 10.7 & 29.2 & 21.6 & 22.8 & 35.4 & 53.0 \\
\hline Exceptional financing & 41.0 & 53.5 & 41.1 & 28.5 & 43.7 & 0.0 & 0.0 \\
\hline ECF credit & 19.4 & 20.2 & 11.0 & 6.4 & 17.3 & 0.0 & 0.0 \\
\hline Other identified financing & 21.6 & 33.3 & 30.1 & 22.1 & 26.4 & 0.0 & 0.0 \\
\hline Residual/unidentified financing ( $+=$ financing needs $)^{5}$ & 1.0 & 0.0 & 2.5 & 5.7 & 0.0 & 43.6 & 43.7 \\
\hline
\end{tabular}


Table 3b. Togo: Central Government Financial Operations, 2009-13 (concluded)

\begin{tabular}{|c|c|c|c|c|c|c|c|}
\hline & \multirow{2}{*}{$\begin{array}{l}2009 \\
\text { Act. }\end{array}$} & \multicolumn{2}{|c|}{2010} & \multicolumn{2}{|c|}{2011} & \multirow{2}{*}{$\begin{array}{l}2012 \\
\text { Proj. }\end{array}$} & \multirow{2}{*}{$\begin{array}{l}2013 \\
\text { Proj. }\end{array}$} \\
\hline & & 5th. Rev. & Act. & 5th. Rev. & Proj. ${ }^{1}$ & & \\
\hline & \multicolumn{7}{|c|}{ (Percent of GDP) } \\
\hline Revenue and grants & 18.5 & 19.6 & 20.9 & 22.6 & 22.2 & 22.7 & 22.7 \\
\hline Total revenue & 16.9 & 17.1 & 18.9 & 19.3 & 18.9 & 18.4 & 18.5 \\
\hline Tax revenue & 15.4 & 15.0 & 15.7 & 16.3 & 15.8 & 16.5 & 16.6 \\
\hline Nontax revenue & 1.6 & 2.1 & 3.2 & 3.1 & 3.0 & 1.9 & 1.9 \\
\hline Grants & 1.5 & 2.4 & 2.0 & 3.3 & 3.4 & 4.3 & 4.2 \\
\hline Expenditures and net lending & 21.3 & 22.4 & 22.5 & 25.3 & 26.1 & 26.8 & 28.3 \\
\hline Of which: Dom. primary expenditures & 17.4 & 17.2 & 16.7 & 19.7 & 20.4 & 19.5 & 20.2 \\
\hline Of Which: temporary social measures & $\ldots$ & $\cdots$ & $\cdots$ & $\ldots$ & 0.2 & 0.0 & 0.0 \\
\hline Current expenditures & 15.8 & 15.6 & 14.7 & 15.5 & 17.2 & 15.3 & 15.7 \\
\hline Domestic primary current spending ${ }^{2}$ & 14.8 & 14.0 & 13.7 & 14.7 & 16.4 & 14.5 & 14.9 \\
\hline Wages and salaries & 6.3 & 5.9 & 5.2 & 5.9 & 5.8 & 6.1 & 6.1 \\
\hline Goods and services & 4.3 & 4.1 & 3.8 & 4.3 & 4.2 & 3.8 & 4.2 \\
\hline Transfers and subsidies & 4.0 & 4.0 & 4.4 & 4.4 & 6.4 & 4.4 & 4.5 \\
\hline Of which: Oil prices support & $\ldots$ & $\ldots$ & $\ldots$ & $\ldots$ & 1.9 & 0.0 & 0.0 \\
\hline Foreign-financed current spending ${ }^{3}$ & 0.0 & 0.7 & 0.0 & 0.0 & 0.0 & 0.0 & 0.0 \\
\hline Interest & 0.9 & 1.0 & 1.0 & 0.8 & 0.8 & 0.8 & 0.8 \\
\hline Public investment & 5.5 & 6.7 & 7.9 & 9.9 & 8.9 & 11.5 & 12.6 \\
\hline Domestically financed & 2.5 & 3.3 & 2.9 & 5.0 & 4.0 & 5.0 & 5.3 \\
\hline Foreign financed ${ }^{3}$ & 3.0 & 3.5 & 4.9 & 4.8 & 4.9 & 6.6 & 7.3 \\
\hline Net lending & 0.0 & 0.0 & 0.0 & 0.0 & 0.0 & 0.0 & 0.0 \\
\hline Current balance & 1.2 & 1.5 & 4.2 & 3.9 & 1.6 & 3.1 & 2.8 \\
\hline Domestic primary balance & -0.4 & -0.1 & 2.2 & -0.4 & -1.6 & -1.1 & -1.7 \\
\hline Overall balance, payment order basis (incl. grants) & -2.8 & -2.8 & -1.6 & -2.7 & -3.9 & -4.1 & -5.6 \\
\hline Excluding grants & -4.4 & -5.2 & -3.7 & -6.0 & -7.3 & -8.4 & -9.8 \\
\hline Change in arrears ${ }^{4}$ & -1.0 & -3.0 & -2.3 & -0.8 & -0.8 & -0.3 & -0.3 \\
\hline Overall balance, cash basis (incl.grants; incl.change in arrears) & -3.9 & -5.8 & -4.0 & -3.5 & -4.7 & -4.4 & -5.9 \\
\hline Excluding grants & -5.4 & -8.2 & -6.0 & -6.8 & -8.1 & -8.7 & -10.1 \\
\hline Financing & 1.1 & 2.4 & 1.2 & 1.4 & 2.1 & 2.0 & 3.6 \\
\hline Domestic financing (net) & 0.9 & 1.7 & -0.7 & 0.1 & 0.8 & 0.1 & 0.9 \\
\hline Banking system & 1.0 & 1.6 & 0.3 & -0.4 & 2.0 & 0.6 & 0.8 \\
\hline Nonbank financing & 0.0 & 0.1 & -1.0 & 0.5 & -1.3 & -0.5 & 0.1 \\
\hline External financing (net) & 0.2 & 0.7 & 1.9 & 1.3 & 1.3 & 1.9 & 2.7 \\
\hline Exceptional financing & 2.8 & 3.4 & 2.6 & 1.7 & 2.6 & 0.0 & 0.0 \\
\hline Residual/unidentified financing $(+=\text { financing needs })^{5}$ & 0.1 & 0.0 & 0.2 & 0.3 & 0.0 & 2.4 & 2.2 \\
\hline Nominal GDP (CFAF billions) & 1,490 & 1,562 & 1,573 & 1,656 & 1,696 & 1,821 & 1,952 \\
\hline
\end{tabular}

Sources: Togolese authorities and IMF staff estimates and projections.

${ }^{1}$ Ratios to GDP reflect upward revision in nominal GDP.

${ }^{2}$ In 2009, expenditures include social and investment spending committed in January 2009 under the 2008 supplementary budget.

${ }^{3}$ The accounting for foreign financed spending was changed in 2010 to facilitate tracking. Instead of attempting to track foreign financed current and investment spending separately, staff and the authorities agreed to track all foreign financed spending under investment spending.

${ }^{4}$ Includes the BCEAO credit for domestic arrears clearance. In 2010 domestic arrears include arrears of noncentral government administration to electricity company; this operation could be registered as transfer.

${ }^{5}$ In keeping with practice under the program, unidentified financing from 2012 on is calculated without assuming any external budget support (i.e. exceptional financing). 
Table 4. Togo: Monetary Survey, 2009-13

\begin{tabular}{|c|c|c|c|c|c|}
\hline & 2009 & 2010 & 2011 & 2012 & 2013 \\
\hline & Actual & Actual & Proj. & Proj. & Proj. \\
\hline & \multicolumn{5}{|c|}{ (Billions of CFA Francs) } \\
\hline Net foreign assets & 241.2 & 259.5 & 274.8 & 273.4 & 280.8 \\
\hline BCEAO & 161.7 & 193.5 & 206.9 & 203.4 & 209.4 \\
\hline Assets & 318.2 & 352.4 & 365.8 & 362.4 & 431.2 \\
\hline Liabilities & -156.5 & -159.0 & -159.0 & -159.0 & -221.8 \\
\hline Commercial banks & 79.5 & 66.0 & 68.0 & 70.0 & 71.4 \\
\hline Assets & 138.2 & 169.8 & 174.9 & 180.1 & 183.7 \\
\hline Liabilities & 58.7 & 103.8 & 106.9 & 110.1 & 112.3 \\
\hline Net domestic assets & 382.1 & 457.1 & 525.5 & 609.3 & 683.5 \\
\hline Credit to government (net) & 112.2 & 131.0 & 165.6 & 176.5 & 193.0 \\
\hline BCEAO & 31.9 & 62.1 & 70.8 & 71.7 & 73.1 \\
\hline Commercial banks & 80.4 & 68.8 & 94.8 & 104.8 & 119.8 \\
\hline Credit to nongovernment sector & 294.7 & 358.5 & 419.4 & 473.9 & 530.8 \\
\hline Other items (net) & -25.1 & -32.6 & -59.6 & -41.2 & -40.2 \\
\hline Money supply (M2) & 616.7 & 717.0 & 800.3 & 882.7 & 964.4 \\
\hline Currency in circulation & 140.3 & 183.3 & 199.1 & 210.3 & 218.8 \\
\hline Bank deposits & 476.4 & 533.7 & 601.2 & 672.4 & 745.5 \\
\hline
\end{tabular}

(Annual change, as a percent of beginning-of-period broad money)

\begin{tabular}{lrrrrr} 
Net foreign assets & 0.7 & 3.0 & 2.1 & -0.2 & 0.8 \\
BCEAO & -4.9 & 5.1 & 1.9 & -0.4 & 0.7 \\
Commercial banks & 5.6 & -2.2 & 0.3 & 0.3 & 0.2 \\
Net domestic assets & 15.4 & 12.2 & 9.5 & 10.5 & 8.4 \\
$\quad$ Credit to government (net) & 6.4 & 3.0 & 4.8 & 1.4 & 1.9 \\
Credit to nongovernment sector & 9.7 & 10.3 & 8.5 & 6.8 & 6.4 \\
Other items (net) & -0.8 & -1.2 & -3.8 & 2.3 & 0.1 \\
Money supply (M2) & 16.2 & 16.3 & 11.6 & 10.3 & 9.2 \\
Currency in circulation & 2.1 & 7.0 & 2.2 & 1.4 & 1.0 \\
Bank deposits & 14.1 & 9.3 & 9.4 & 8.9 & 8.3 \\
Memorandum items: & & & & & \\
Velocity (GDP/end-of-period M2) & 2.4 & 2.2 & 2.1 & 2.1 & 2.0 \\
\hline Sources: Cent Bank of West Afican
\end{tabular}

Sources: Central Bank of West African States and IMF staff estimates and projections. 
Table 5. Togo: Medium-Term Outlook 2010-16 ${ }^{1}$

\begin{tabular}{|c|c|c|c|c|c|c|c|}
\hline & 2010 & 2011 & 2012 & 2013 & 2014 & 2015 & 2016 \\
\hline & \multicolumn{7}{|c|}{ (Annual percentage change) } \\
\hline \multicolumn{8}{|l|}{ National accounts } \\
\hline Real GDP & 3.7 & 3.9 & 4.5 & 4.7 & 4.9 & 4.5 & 4.4 \\
\hline Primary sector & 2.5 & 3.9 & 3.6 & 3.1 & 3.3 & 3.4 & 3.7 \\
\hline Secondary sector & 6.4 & 4.8 & 6.8 & 8.1 & 7.9 & 7.0 & 7.0 \\
\hline Tertiary sector & 4.9 & 2.7 & 4.8 & 5.4 & 5.7 & 4.7 & 4.0 \\
\hline GDP deflator & 1.8 & 3.8 & 2.7 & 2.4 & 2.6 & 2.0 & 2.2 \\
\hline CPI inflation (average) & 1.4 & 4.3 & 2.6 & 2.4 & 2.3 & 2.1 & 2.0 \\
\hline \multirow[t]{2}{*}{ Terms of trade } & -0.2 & -1.6 & -1.6 & -0.4 & 0.4 & 0.0 & -0.1 \\
\hline & \multicolumn{7}{|c|}{ (Percent of GDP; unless otherwise indicated) } \\
\hline \multicolumn{8}{|l|}{ National accounts } \\
\hline Investment & 18.9 & 19.4 & 21.8 & 22.7 & 23.1 & 20.6 & 20.8 \\
\hline Government & 7.9 & 8.9 & 11.5 & 12.6 & 12.6 & 9.6 & 9.6 \\
\hline Nongovernment & 11.0 & 10.5 & 10.3 & 10.1 & 10.5 & 11.0 & 11.2 \\
\hline Savings & 11.7 & 11.7 & 13.7 & 14.4 & 14.9 & 13.3 & 14.1 \\
\hline Government & 6.2 & 5.0 & 7.4 & 7.0 & 6.9 & 6.8 & 6.7 \\
\hline Nongovernment & 5.4 & 6.8 & 6.4 & 7.3 & 8.0 & 6.5 & 7.4 \\
\hline \multicolumn{8}{|l|}{ Government } \\
\hline Total revenue and grants & 20.9 & 22.2 & 22.7 & 22.7 & 22.7 & 22.6 & 22.6 \\
\hline Revenues & 18.9 & 18.9 & 18.4 & 18.5 & 18.5 & 18.5 & 18.5 \\
\hline Total expenditure & 22.5 & 26.1 & 26.8 & 28.3 & 28.4 & 25.4 & 25.5 \\
\hline Domestic primary spending & 16.7 & 20.4 & 19.5 & 20.2 & 20.2 & 18.7 & 18.7 \\
\hline Overall balance & -1.6 & -3.9 & -4.1 & -5.6 & -5.7 & -2.8 & -2.9 \\
\hline Domestic primary balance & 2.2 & -1.6 & -1.1 & -1.7 & -1.7 & -0.2 & -0.2 \\
\hline \multicolumn{8}{|l|}{ External sector } \\
\hline Current account balance & -7.2 & -7.6 & -8.1 & -8.3 & -8.2 & -7.3 & -6.7 \\
\hline Exports of goods and services & 37.3 & 37.4 & 37.1 & 37.2 & 37.2 & 37.3 & 37.4 \\
\hline Imports of goods and services & -53.8 & -55.1 & -55.8 & -56.0 & -55.6 & -54.5 & -53.9 \\
\hline External public debt ${ }^{2}$ & 17.2 & 16.0 & 17.1 & 19.2 & 20.9 & 20.8 & 20.7 \\
\hline Total public debt ${ }^{2}$ & 32.3 & 27.4 & 27.1 & 27.8 & 27.8 & 26.3 & 27.0 \\
\hline
\end{tabular}

Sources: Togolese authorities and IMF staff estimates and projections.

${ }^{1}$ Assumes structural reforms, fiscal adjustment, and continued donor support in 2010-16.

${ }^{2}$ Includes arrears and state-owned enterprises external debt. 
Table 6. Togo: Actual and Proposed Schedule of Disbursement Under ECF Arrangement, 2008-11

\begin{tabular}{|c|c|c|c|c|c|}
\hline \multicolumn{4}{|c|}{ Amount } & \multirow[t]{2}{*}{ Date } & \multirow[t]{2}{*}{ Condition for Disbursement ${ }^{1}$} \\
\hline & Total & $\begin{array}{l}\text { Original } \\
\text { program }\end{array}$ & Augmentation & & \\
\hline SDR & $13,260,000$ & $13,260,000$ & & April 30, 2008 & $\begin{array}{l}\text { Executive Board approval of the three-year arrangement under the ECF arrangement (April } \\
23,2008)\end{array}$ \\
\hline SDR & $17,975,000$ & $8,800,000$ & $9,175,000$ & September 22, 2008 & $\begin{array}{l}\text { Observance of performance criteria for end-June } 2008 \text { and other relevant performance } \\
\text { criteria, and completion of the first review under the ECF arrangement }\end{array}$ \\
\hline SDR & $17,975,000$ & $8,800,000$ & $9,175,000$ & April 30, 2009 & $\begin{array}{l}\text { Observance of performance criteria for end-December } 2008 \text { and other relevant } \\
\text { performance criteria, and completion of the second review under the ECF arrangement }\end{array}$ \\
\hline SDR & $8,800,000$ & $8,800,000$ & & November 11, 2009 & $\begin{array}{l}\text { Observance of performance criteria for end-June } 2009 \text { and other relevant performance } \\
\text { criteria, and completion of the third review under the ECF arrangement }\end{array}$ \\
\hline SDR & $14,300,000$ & $8,800,000$ & $5,500,000$ & June 30, 2010 & $\begin{array}{l}\text { Observance of performance criteria for end-December } 2009 \text { and other relevant } \\
\text { performance criteria, and completion of the fourth review under the ECF arrangement }\end{array}$ \\
\hline SDR & $14,300,000$ & $8,800,000$ & $5,500,000$ & October 31, 2010 & $\begin{array}{l}\text { Observance of performance criteria for end-June } 2010 \text { and other relevant performance } \\
\text { criteria, and completion of the fifth review under the ECF arrangement }\end{array}$ \\
\hline SDR & $8,800,000$ & $8,800,000$ & & April 30, 2011 & $\begin{array}{l}\text { Observance of performance criteria for end-December } 2010 \text { and other relevant } \\
\text { performance criteria, and completion of the sixth review under the ECF arrangement }\end{array}$ \\
\hline
\end{tabular}

${ }^{1}$ Other than the generally applicable conditions for the Extended Credit Facility (ECF). 
Table 7. Togo: Official External Debt, 2009-12

\begin{tabular}{|c|c|c|c|c|c|c|c|c|c|}
\hline & & & & \multicolumn{6}{|c|}{ Debt Service (proj.) } \\
\hline & \multicolumn{3}{|c|}{2009} & \multicolumn{2}{|c|}{2010} & \multicolumn{2}{|c|}{2011} & \multicolumn{2}{|c|}{2012} \\
\hline & $\begin{array}{l}\text { Nominal } \\
\text { Stock }\end{array}$ & $\begin{array}{l}\text { Of which } \\
\text { Arrears }{ }^{1}\end{array}$ & PV of Debt ${ }^{2}$ & Amort. & Interest & Amort. & Interest & Amort. & Interest \\
\hline & \multicolumn{9}{|c|}{ (US\$ millions) } \\
\hline Total & $1,748.2$ & 20.1 & $1,410.9$ & 47.3 & 13.1 & 27.9 & 11.9 & 29.2 & 13.4 \\
\hline Multilateral & 998.6 & 2.2 & 731.5 & 37.1 & 11.0 & 10.9 & 7.5 & 10.8 & 5.1 \\
\hline Bilateral and commercial & 749.7 & 18.0 & 679.3 & 10.2 & 2.1 & 17.0 & 4.4 & 18.4 & 8.3 \\
\hline Bilateral & 725.5 & 4.2 & 653.6 & 10.2 & 1.2 & 15.9 & 1.5 & 17.3 & 2.7 \\
\hline Paris Club & 605.9 & 0.0 & 555.2 & 0.0 & 0.0 & 3.6 & 0.4 & 10.0 & 1.6 \\
\hline Other official bilateral & 119.6 & 4.2 & 98.5 & 10.2 & 1.2 & 12.4 & 1.1 & 7.4 & 1.0 \\
\hline \multirow[t]{2}{*}{ Commercial } & 24.2 & 13.8 & 25.7 & 0.0 & 0.9 & 1.0 & 2.8 & 1.0 & 5.7 \\
\hline & \multicolumn{9}{|c|}{ (CFAF billions) } \\
\hline Total & 785.0 & 9.0 & 633.6 & 23.5 & 6.5 & 12.7 & 5.4 & 13.5 & 6.2 \\
\hline Multilateral & 448.4 & 1.0 & 328.5 & 18.4 & 5.4 & 5.0 & 3.4 & 5.0 & 2.4 \\
\hline Bilateral and commercial & 336.6 & 8.1 & 305.1 & 5.1 & 1.0 & 7.7 & 2.0 & 8.5 & 3.9 \\
\hline Bilateral & 325.8 & 1.9 & 293.5 & 5.1 & 0.6 & 7.3 & 0.7 & 8.0 & 1.2 \\
\hline Paris Club & 272.1 & 0.0 & 249.3 & 0.0 & 0.0 & 1.6 & 0.2 & 4.6 & 0.8 \\
\hline Other official bilateral & 53.7 & 1.9 & 44.2 & 5.1 & 0.6 & 5.6 & 0.5 & 3.4 & 0.5 \\
\hline \multirow[t]{2}{*}{ Commercial } & 10.9 & 6.2 & 11.5 & 0.0 & 0.5 & 0.5 & 1.3 & 0.5 & 2.6 \\
\hline & \multicolumn{9}{|c|}{ (Percent of GDP) } \\
\hline Total & 52.7 & 0.6 & 42.5 & 1.5 & 0.4 & 0.7 & 0.3 & 0.7 & 0.3 \\
\hline Multilateral & 30.1 & 0.1 & 22.0 & 1.2 & 0.3 & 0.3 & 0.2 & 0.3 & 0.1 \\
\hline Bilateral and commercial & 22.6 & 0.5 & 20.5 & 0.3 & 0.1 & 0.5 & 0.1 & 0.5 & 0.2 \\
\hline Bilateral & 21.9 & 0.1 & 19.7 & 0.3 & 0.0 & 0.4 & 0.0 & 0.4 & 0.1 \\
\hline Paris Club & 18.3 & 0.0 & 16.7 & 0.0 & 0.0 & 0.1 & 0.0 & 0.3 & 0.0 \\
\hline Other official bilateral & 3.6 & 0.1 & 3.0 & 0.3 & 0.0 & 0.3 & 0.0 & 0.2 & 0.0 \\
\hline \multirow[t]{2}{*}{ Commercial } & 0.7 & 0.4 & 0.8 & 0.0 & 0.0 & 0.0 & 0.1 & 0.0 & 0.1 \\
\hline & \multicolumn{9}{|c|}{ (Percent of revenue) } \\
\hline Total & 311.0 & 3.6 & 251.0 & 7.9 & 2.2 & 4.0 & 1.7 & 4.0 & 1.9 \\
\hline Multilateral & 177.7 & 0.4 & 130.2 & 6.2 & 1.8 & 1.6 & 1.1 & 1.5 & 0.7 \\
\hline Bilateral and commercial & 133.4 & 3.2 & 120.9 & 1.7 & 0.4 & 2.4 & 0.6 & 2.5 & 1.2 \\
\hline Bilateral & 129.1 & 0.7 & 116.3 & 1.7 & 0.2 & 2.3 & 0.2 & 2.4 & 0.4 \\
\hline Paris Club & 107.8 & 0.0 & 98.8 & 0.0 & 0.0 & 0.5 & 0.1 & 1.4 & 0.2 \\
\hline Other official bilateral & 21.3 & 0.7 & 17.5 & 1.7 & 0.2 & 1.8 & 0.2 & 1.0 & 0.1 \\
\hline Commercial & 4.3 & 2.5 & 4.6 & 0.0 & 0.2 & 0.1 & 0.4 & 0.1 & 0.8 \\
\hline \multicolumn{10}{|l|}{ Memorandum items: } \\
\hline Nominal GDP (CFAF billions) & $1,490.3$ & $1,490.3$ & $1,490.3$ & $1,573.1$ & $1,573.1$ & $1,696.1$ & $1,696.1$ & $1,820.7$ & $1,820.7$ \\
\hline Revenue (CFAF billions) & 252.4 & 252.4 & 252.4 & 296.9 & 296.9 & 319.8 & 319.8 & 335.0 & 335.0 \\
\hline Exchange rate CFAF/USD (end of year) & 449.0 & 449.0 & 449.0 & 496.1 & 496.1 & 455.8 & 455.8 & 462.3 & 462.3 \\
\hline
\end{tabular}

Sources: Togolese authorities; and IMF and World Bank staff es timates.

${ }^{1}$ Includes principal and interest in arrears.

${ }^{2}$ Includes arrears. 
Table 8. Togo: Indicators of Capacity to Repay the Fund, 2010/2021

\begin{tabular}{|c|c|c|c|c|c|c|c|c|c|c|c|c|}
\hline & 2010 & 2011 & 2012 & 2013 & 2014 & 2015 & 2016 & 2017 & 2018 & 2019 & 2020 & 2021 \\
\hline & \multicolumn{11}{|c|}{ Projections } & \\
\hline \multicolumn{13}{|c|}{$\begin{array}{l}\text { Fund obligations based on existing and prospective credit } \\
\text { (in millions of SDRs) }\end{array}$} \\
\hline & 0.0 & 0.0 & 0.0 & 1.2 & 8.0 & 11.6 & 17.3 & 19.1 & 17.8 & 11.0 & 7.5 & 1.8 \\
\hline Charges and interest ${ }^{1}$ & 0.0 & 0.0 & 0.3 & 0.3 & 0.3 & 0.3 & 0.2 & 0.2 & 0.1 & 0.1 & 0.1 & 0.1 \\
\hline \multicolumn{13}{|c|}{ Total obligations based on existing and prospective credit } \\
\hline In millions of SDRs & 0.0 & 0.0 & 0.3 & 1.5 & 8.3 & 11.9 & 17.6 & 19.3 & 17.9 & 11.1 & 7.6 & 1.8 \\
\hline In billions of CFAF & 0.0 & 0.0 & 0.2 & 1.1 & 6.2 & 8.9 & 13.2 & 14.5 & 13.5 & 8.4 & 5.7 & 1.4 \\
\hline In percent of government revenue & 0.0 & 0.0 & 0.1 & 0.3 & 1.6 & 2.1 & 3.0 & 3.1 & 2.7 & 1.6 & 1.0 & 0.2 \\
\hline In percent of exports of goods and services & 0.0 & 0.0 & 0.0 & 0.1 & 0.8 & 1.1 & 1.5 & 1.5 & 1.3 & 0.8 & 0.5 & 0.1 \\
\hline In percent of debt service ${ }^{2}$ & 0.1 & 0.1 & 1.1 & 4.9 & 21.0 & 26.8 & 34.2 & 31.9 & 27.2 & 17.9 & 11.8 & 2.6 \\
\hline In percent of GDP & 0.0 & 0.0 & 0.0 & 0.1 & 0.3 & 0.4 & 0.6 & 0.6 & 0.5 & 0.3 & 0.2 & 0.0 \\
\hline In percent of quota & 0.1 & 0.0 & 0.4 & 2.0 & 11.3 & 16.2 & 23.9 & 26.2 & 24.4 & 15.2 & 10.3 & 2.5 \\
\hline \multicolumn{13}{|l|}{ Outstanding IMF credit } \\
\hline In millions of SDRs & 86.6 & 95.4 & 95.4 & 94.1 & 86.0 & 73.0 & 54.8 & 35.7 & 18.0 & 6.9 & 0.9 & 0.0 \\
\hline In billions of CFAF & 65.3 & 69.9 & 69.9 & 69.5 & 64.1 & 54.7 & 41.3 & 26.9 & 13.5 & 5.2 & 0.7 & 0.0 \\
\hline In percent of government revenue & 22.0 & 21.9 & 20.9 & 19.3 & 16.5 & 13.2 & 9.3 & 5.7 & 2.7 & 1.0 & 0.1 & 0.0 \\
\hline In percent of exports of goods and services & 11.1 & 11.0 & 10.3 & 9.6 & 8.2 & 6.5 & 4.6 & 2.8 & 1.3 & 0.5 & 0.1 & 0.0 \\
\hline In percent of debt service ${ }^{2}$ & 218.9 & 381.8 & 356.8 & 313.5 & 216.4 & 164.6 & 106.9 & 59.1 & 27.3 & 11.2 & 1.4 & 0.0 \\
\hline In percent of GDP & 4.2 & 4.1 & 3.8 & 3.6 & 3.1 & 2.4 & 1.7 & 1.1 & 0.5 & 0.2 & 0.0 & 0.0 \\
\hline In percent of quota & 118.0 & 130.0 & 130.0 & 128.2 & 117.2 & 99.5 & 74.7 & 48.7 & 24.5 & 9.4 & 1.2 & 0.0 \\
\hline Net use of IMF credit (millions of SDRs) & 28.6 & 8.8 & 0.0 & -1.2 & -8.0 & -11.6 & -17.3 & -19.1 & -17.8 & -11.0 & -7.5 & -1.8 \\
\hline Disbursements & 28.6 & 8.8 & 0.0 & 0.0 & 0.0 & 0.0 & 0.0 & 0.0 & 0.0 & 0.0 & 0.0 & 0.0 \\
\hline Repayments and repurchases & 0.0 & 0.0 & 0.0 & 1.2 & 8.0 & 11.6 & 17.3 & 19.1 & 17.8 & 11.0 & 7.5 & 1.8 \\
\hline \multicolumn{13}{|l|}{ Memorandum items: } \\
\hline Nominal GDP (in billions of CFAF) & 1573.1 & 1696.1 & 1820.7 & 1951.9 & 2101.2 & 2237.7 & 2387.2 & 2545.6 & 2711.1 & 2892.1 & 3077.7 & 3279.1 \\
\hline Exports of goods and services (in billions of CFAF) & 586.9 & 634.5 & 676.0 & 725.6 & 782.1 & 835.5 & 891.6 & 949.6 & 1012.0 & 1078.8 & 1151.4 & 1228.5 \\
\hline Government revenue (in billions of CFAF) & 296.9 & 319.8 & 335.0 & 361.1 & 388.7 & 414.0 & 441.6 & 470.9 & 501.6 & 535.0 & 569.4 & 607.3 \\
\hline Debt service (in billions of CFAF) ${ }^{23}$ & 29.8 & 18.3 & 19.6 & 22.2 & 29.6 & 33.3 & 38.6 & 45.5 & 49.6 & 46.8 & 48.3 & 51.9 \\
\hline
\end{tabular}

${ }^{1}$ Reflecting temporary interest relief on PRGT interest obligations through end-2011 in the context of the reform of LIC facilities.

2 Total debt service includes IMF repurchases and repayments.

${ }^{3}$ Includes state-owned enterprises debt. 
Table 9. Togo: WAEMU Convergence Criteria, 2007/2012

(Ratios in percent, unless otherwise indicated)

$\begin{array}{llllllr}\text { Ratio } & 2007 & 2008 & 2009 & 2010 & 2011 & 2012\end{array}$

\section{Primary criteria}

Primary balance/GDP

Inflation (annual average)

Stock of debt/GDP

Domestic arrears accumulation, net (in billions of CFA francs)

External arrears accumulation (in billions of CFA francs)

Proj. Proj.

\section{Secondary criteria}

Wages and salaries/tax revenue

Domestically financed investment/tax revenue

External current account deficit, excluding official transfers/GDP

Tax revenue/GDP

$\begin{array}{rrrrrrr}>=0 & -2.7 & -0.7 & -1.4 & 1.3 & -2.5 & -1.9 \\ <=3 & 0.9 & 8.7 & 1.9 & 1.4 & 3.9 & 2.5 \\ <=70 & 105.8 & 78.1 & 70.3 & 32.2 & 27.6 & 27.1 \\ <=0 & -9.3 & 0.0 & -16.5 & -36.9 & -13.2 & -5.5 \\ <=0 & 38.6 & -0.6 & 0.0 & 0.0 & 0.0 & 0.0 \\ & & & & & & \\ <=35 & 32.8 & 32.7 & 41.1 & 33.5 & 36.2 & 37.0 \\ >=20 & 7.1 & 10.6 & 16.6 & 18.7 & 31.0 & 30.1 \\ <=-5 & -8.1 & -8.3 & -8.2 & -9.2 & -11.1 & -12.4 \\ >=17 & 16.2 & 14.9 & 15.4 & 15.7 & 15.9 & 16.5\end{array}$

Source: Togolese authorities. 
Table 10. Togo: Selected Indicators on the Millennium Development Goals 1990/2009

\begin{tabular}{|c|c|c|c|c|}
\hline & 1990 & 1995 & 2000 & 2009 \\
\hline Goal 1: Eradicate extreme poverty and hunger & \multicolumn{4}{|c|}{ (2015 target: halve $1990 \$ 1$ a day poverty and malnutrition rates) } \\
\hline Employment to population ratio, $15+$, total $(\%)$ & 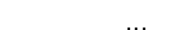 & 65 & 65 & 65 \\
\hline Employment to population ratio, ages $15 / 24$, total (\%) & $\ldots$ & 57 & 55 & 53 \\
\hline Malnutrition prevalence, weight for age ( $\%$ of children under 5 ) & 21 & $\ldots$ & 23 & $\ldots$ \\
\hline Goal 2: Achieve universal primary education & \multicolumn{4}{|c|}{ (2015 target: net enrollment to 100 ) } \\
\hline $\begin{array}{l}\text { Literacy rate, youth female ( } \% \text { of females ages } 15 / 24) \\
\text { Literacy rate, youth male ( } \% \text { of males ages } 15 / 24)\end{array}$ & $\begin{array}{l}\cdots \\
\cdots\end{array}$ & $\begin{array}{l}\cdots \\
\ldots\end{array}$ & $\begin{array}{l}64 \\
84\end{array}$ & $\begin{array}{l}\ldots \\
\ldots\end{array}$ \\
\hline Primary completion rate, total (\% of relevant age group) & 35 & 39 & 61 & 67 \\
\hline Total enrollment, primary (\% net) & $\ldots$ & $\ldots$ & 78 & 80 \\
\hline Goal 3: Promote gender equality and empower women & \multicolumn{4}{|c|}{ (2015 target: education ratio 100) } \\
\hline Proportion of seats held by women in national parliament (\%) & 5 & $\ldots$ & 1 & 7 \\
\hline Ratio of female to male primary enrollment & $\ldots$ & $\ldots$ & 78 & 86 \\
\hline Ratio of female to male secondary enrollment & $\ldots$ & $\ldots$ & 44 & 51 \\
\hline Ratio of young literate females to males (\% ages $15 / 24$ ) & $\ldots$ & $\ldots$ & 76 & $\ldots$ \\
\hline Goal 4: Reduce child mortality & \multicolumn{4}{|c|}{ (2015 target: reduce 1990 under 5 mortality by tw o-thirds) } \\
\hline Immunization, measles ( $\%$ of children ages $12 / 23$ months) & 73 & 53 & 58 & 84 \\
\hline Mortality rate, infant (per 1,000 live births) & 89 & 86 & 78 & 64 \\
\hline Mortality rate, under-5 (per 1,000$)$ & 150 & 142 & 124 & 98 \\
\hline Goal 5: Improve maternal health & \multicolumn{4}{|c|}{ (2015 target: reduce 1990 maternal mortality by three-fourths) } \\
\hline Adolescent fertility rate (births per 1,000 women ages $15 / 19$ ) & & $\ldots$ & 86 & 64 \\
\hline Births attended by skilled health staff (\% of total) & 31 & $\ldots$ & 49 & 62 \\
\hline Contraceptive prevalence (\% of women ages 15/49) & 34 & $\ldots$ & 26 & 17 \\
\hline Maternal mortality ratio (modeled estimate, per 100,000 live births) & 650 & 550 & 450 & 350 \\
\hline Pregnant women receiving prenatal care $(\%)$ & 43 & $\ldots$ & 73 & 84 \\
\hline Goal 6: Combat HIVIAIDS, malaria, and other diseases & \multicolumn{4}{|c|}{ (2015 target: halt, and begin to reverse AIDS, etc.) } \\
\hline Children with fever receiving antimalarial drugs (\% of children under age 5 with fever) & & $\ldots$ & 60 & 48 \\
\hline Incidence of tuberculosis (per 100,000 people) & 310 & 340 & 370 & 440 \\
\hline Prevalence of HIV, female (\% ages $15 / 24)$ & $\ldots$ & $\ldots$ & $\ldots$ & 2.4 \\
\hline Prevalence of HIV, total (\% of population ages $15 / 49$ ) & 0.7 & 3 & 3.6 & 3.3 \\
\hline Tuberculosis cases detected under DOTS $(\%)$ & 11 & 10 & 7 & 10 \\
\hline Goal 7: Ensure environmental sustainability & \multicolumn{4}{|c|}{ (2015 target: various) } \\
\hline CO2 emissions (kg per PPP \$ of GDP) & 0 & 0 & 0 & 0 \\
\hline CO2 emissions (metric tons per capita) & 0 & 0 & 0 & 0 \\
\hline Forest area (\% of land area) & 12.6 & $\ldots$ & 8.9 & 6.7 \\
\hline Improved sanitation facilities (\% of population with access) & 13 & 12 & 12 & 12 \\
\hline Improved water source (\% of population with access) & 49 & 52 & 55 & 60 \\
\hline Goal 8: Develop a global partnership for development & \multicolumn{4}{|c|}{ (2015 target: various) } \\
\hline Aid per capita (current US\$) & 66 & 43 & 13 & 51 \\
\hline Debt service (PPG and IMF only, \% of exports of G\&S, excl. workers' remittances) & 11 & 5 & 5 & 10 \\
\hline Internet users (per 100 people) & 0 & 0 & 1.9 & 5.4 \\
\hline Mobile phone subscribers (per 100 people) & 0 & 0 & 1 & 24 \\
\hline Telephone mainlines (per 100 people) & 0 & 0 & 1 & 2 \\
\hline \multicolumn{5}{|l|}{ Other } \\
\hline Fertility rate, total (births per woman) & 6 & 6 & 5 & 4 \\
\hline GNI per capita, Atlas method (current US\$) & 390 & 290 & 280 & 440 \\
\hline GNI, Atlas method (current US\$ billions) & 1.5 & 1.3 & 1.5 & 2.9 \\
\hline Gross capital formation (\% of GDP) & 26.6 & 16.1 & 17.8 & 18.4 \\
\hline Life expectancy at birth, total (years) & 58 & 59 & 60 & 63 \\
\hline Literacy rate, adult total (\% of people ages 15 and above) & $\ldots$ & $\ldots$ & 53 & 65 \\
\hline Population, total (millions) & 4 & 4.5 & 5.4 & 6.5 \\
\hline Trade $(\%$ of GDP) & 78.8 & 69.8 & 81.5 & 104.4 \\
\hline
\end{tabular}

Source: World Development Indicators database.

Note: Italic figures refer to previous year and ... to not available data. 


\title{
Appendix I-Letter of Intent
}

Lomé, June 28, 2011

\section{THE MINISTER}

\author{
Mr. John Lipsky \\ Acting Managing Director \\ International Monetary Fund \\ Washington, D.C. 20431
}

Dear Mr. Lipsky:

1. Further to our letter of November 15, 2010, we take the opportunity of the sixth and final review of the program supported by the Extended Credit Facility (ECF) to take stock of program implementation and report on the outlook for the future.

2. We continue to carry out our economic program and structural reforms in a generally satisfactory manner in pursuit of our goals of maintaining macroeconomic stability and fostering stronger and more sustained growth. The basic framework of the 2011 budget that we prepared with Fund staff during the fifth review continues to guide our policies. However, we experienced the exogenous shocks that we felt compelled to absorb through unplanned expenditures, which will have an impact on the composition of our spending for the year. Nevertheless, the strategic budgetary orientations remain unchanged in promoting faster growth, while taking account of our desire to maintain social stability and preserve the gains of the program.

3. Indeed, the surge in petroleum product prices occurred at the same time as we were raising electricity prices in order to reduce the subsidies to the Togo Electricity Company (CEET), which was running losses. Combined with high prices for imported foodstuffs, this situation was not conducive to beginning to implement the petroleum product price adjustment mechanism in January 2011, as planned. Despite these immediate difficulties, our economic performance is continuing to improve, both in terms of growth and investor confidence in Togo's future.

\section{Recent economic developments}

4. The economic recovery that began in 2009 strengthened in 2010, boosting real GDP growth to 3.7 percent in a context of generally moderate inflation. This recovery was supported primarily by a recovery in the cotton sector, buoyant activity at the Autonomous Port of Lomé (especially the end-year increase in transit trade), and the public works launched by the government. Inflation remained moderate at 1.4 percent in 2010 despite the surge in the 
international prices of food and petroleum products, thanks to a satisfactory food harvest, the predominance of subsistence agriculture, to the large share of locally produced food in the consumption basket of the Togolese people, and the subsidization of petroleum products.

5. According to our estimates, the current account deficit worsened to about 7.2 percent of GDP in 2010, compared to 6.6 percent in 2009, despite an improvement in current transfers. This is explained by a significant increase in imports, owing mainly to rising international prices for petroleum product and imports of intermediate and capital goods associated with the start of major infrastructure projects. The value of exports increased only moderately, due notably to a drop in phosphate exports.

6. The money supply grew by 16.3 percent in 2010 , according to the monetary survey. This was the result of an annual increase in domestic credit of nearly 20 percent, driven mainly by a 21.6 percent increase in credit to the economy. The rebound in economic confidence stimulated a pick up in the lending activities of the banking system.

7. In 2011, the government intends to continue implementing measures to accelerate growth while preserving macroeconomic stability in a context of social peace. To this end, it plans to speed up implementation of the public investment program already underway, and to mitigate the impact on households of the surge in petroleum product prices, while ensuring that prices ultimately reflect market conditions. The government also intends to continue implementing the structural reforms that have been initiated.

\section{Program implementation}

8. The ECF-supported economic and financial program has generally been successfully implemented, consistent with its objectives. We have not accumulated any external arrears nor contracted or guaranteed any nonconcessional external debt. In addition, the fiscal performance at end-December 2010 meets the performance criteria established under the program.

\section{Fiscal policy}

\section{Budget execution in 2010}

9. Fiscal performance in 2010 was very satisfactory, with revenue exceeding the targets set under the program and with expenditure maintained within the agreed ceilings. Total revenue increased by 17.6 percent in 2010 compared to 2009. This was to the result of the economic recovery and the improved efficiency of tax administration. Nontax revenue doubled on account of dividends and the renewal of mobile telephony licenses. Consequently, the revenue collected reached CFAF 296.9 billion, exceeding the initial target of CFAF 267.6 billion. We have strictly adhered to planned domestic primary expenditure, which totaled CFAF 261.9 billion, below the programmed level of CFAF 269.3 billion. Consequently, the primary basic balance at endDecember 2010 was CFAF 34.9 billion, compared to a deficit floor of CFAF 1.8 billion under the program. The performance criterion was thus met by a large margin. 
10. These results, combined with the slow pace at which our creditors are claiming payment of the commercial arrears for which resources are available (see Paragraph 21), also enabled us to observe the performance criterion for domestic financing by a large margin. The arrears paid came to CFAF 36.9 billion, compared with a programmed level of CFAF 46.8 billion. Thus, net domestic financing amounted to CFAF -10.6 billion compared to an adjusted ceiling of CFAF 36.4 billion.

\section{The 2011 budget framework}

11. Notwithstanding the marked impact of international price shocks, particularly for petroleum products, we are determined to continue the fiscal policy defined in our economic program for 2011. Budget execution in the first quarter of the year proceeded normally. Tax revenue collected amounted to CFAF 63.7 billion, or 24 percent of the target for the year as a whole. Despite the sharp increase in investment expenditure, its execution rate has remained stable - during the first quarter of the year, we executed 6.9 percent of the approved investment budget compared to 5.9 percent for the same period in 2010. In turn, current expenditure is in line with budget forecasts, except for the cost of petroleum product subsidies.

12. Indeed, our economy sustained setbacks resulting from the changes in petroleum product prices, to which it remains vulnerable. Petroleum product prices have a significant impact on the cost of living and, therefore, on social stability. A surge in the prices of some imported food products exacerbated this problem. In this context, the government felt compelled to cushion the impact of this increase by suspending the application of automatic adjustment mechanism for adjusting prices at the pump. However, this decision had significant impact on the State budget, with costs totaling approximately CFAF 15.8 billion by end-May.

13. Given that the oil price shock has proven to be more persistent than initially expected, the government decided to begin to apply the petroleum product price adjustment mechanism in early June. The mechanism provides for the full pass-through of world prices with some smoothing to limit price changes to 5 percent per month and to a maximum annual increase of 30 percent. Even with these price adjustments, the additional fiscal cost in 2011, over and above the cost incurred through May 30, 2011, will amount to about CFAF 16 billion. The total estimated cost for the year is thus CFAF 31.8 billion. The decision to implement the automatic fuel price adjustment was reached following a social dialogue on the impact of this policy and accompanying mitigating measures.

14. This dialogue resulted in an understanding to implement a number of temporary, targeted social measures at a cost of CFAF 3.8 billion in 2011, including the suspension of direct taxes on transporters, so as to reduce their costs, and the granting of transportation allowances for university students, as well as government employees, pensioners, and salaried workers in the private sector earning less than CFAF 35,000, or the equivalent of US\$76, a month.

15. In order to offset the cost of the delayed pass-through of changes in world oil prices, we have identified, in consultation with IMF staff, investment expenditures to be deferred to the 
2012 budget. To this end, a draft supplementary budget will be submitted to the National Assembly.

16. Following these changes, we have revised our expenditure targets for 2011. Regarding domestic primary expenditures, the target for domestic primary expenditures would go from CFAF 326.8 billion to CFAF 346.3 billion, considering the costs of subsidies to petroleum product prices, social expenditures, and savings to be realized to finance the subsidy. As far as revenue is concerned, the target will change from CFAF 320.2 billion to CFAF 319.8 billion. In particular, we intend to collect all the budgeted nontax revenue, with the possible exception of dividends from the phosphate company (SNPT). To achieve these targets, we will remain vigilant with regard to the performance of the state-owned enterprises and, in particular, to completing the sale of the third mobile telephony license, a process which has experienced delays. In the event that the revenue anticipated in the 2011 budget from the sale of the third mobile telephony license is not collected, we intend to postpone an equivalent level of investment expenditures to the 2012 budget. Consequently, we have revised our objective for the domestic primary deficit to CFAF 26.5 billion (1.6 percent of GDP), a budgetary framework that remains consistent with our objectives for growth and the sustainability of public finances.

17. The ceiling on domestic financing of the budget has been reduced, since the impact of the delayed receipt in January by the Treasury of the disbursement associated with the fifth ECF review exceeded the impact on the primary budget balance of the expenditures associated with the social measures discussed above. With the new budgetary support from the AfDB (CFAF 5 billion), our financing requirements for 2011 should be covered. In order to continue to improve the monitoring of budget execution, we have updated the quarterly indicative targets on the execution of the 2011 budget (Table 1). We will continue to ensure strict compliance with the ceilings on projected current and investment expenditure, and budget execution will continue to be consistent with the financing available.

18. In addition, public finance management reforms (see Paragraphs 20-22) should lead to greater efficiency in expenditure planning and execution and in resource mobilization. To implement our action plan for public finance reform, we have requested technical assistance from the IMF, in the form of both strategic support from headquarters and operational support from AFRITAC West. With regard to tax administration, we look forward to the arrival of an IMF mission to take stock of the progress made so far and to propose new measures to strengthen our reform strategy.

\section{Implementation of the structural reforms}

19. We continued to make progress in implementing the planned structural reforms envisaged needed to meet the objectives of the ECF-supported program. Considerable progress has been made since the last review in December 2010 (Table 2). 


\section{Fiscal governance}

20. Our treasury cash management has improved considerably during the program period. However, there is still much progress to be made in terms of cash flow forecasting. We continue to benefit from IMF technical support through AFRITAC West and issued the decree establishing the treasury committee in December 2010 (end-January 2011 benchmark), thereby putting in place all the institutional structures necessary for the effective implementation of the recommendations made to us in this area. The treasury cash management committee has become operational.

21. As indicated in our letter of November 2010, we have made considerable progress toward establishing a single treasury account. We have initiated a collaborative process with donors and the sectoral ministries with a view to devising and adopting a strategy aimed at effectively achieving a single treasury account; this process has led to delays with respect to our objectives (end-March 2011 benchmark). Technical assistance from the IMF will be required, as will the collaboration of our partners, particularly as far as the project accounts are concerned. For our part, we are now examining approaches to reducing the number of our accounts with the central bank. With regard to commercial arrears, for which the clearing process continues, the government has paid all creditors that have come forward to sign debt settlement agreements, for an additional amount of CFAF 3.7 billion since the end of August 2010, when we reported to the IMF Executive Board on developments in this regard in the context of the last program review. However, since then the process has advanced slowly. Nevertheless, we are committed to continue paying creditors until the end of the statute of limitations, namely end-June 2013.

22. The reforms of our public finance systems are continuing with the support of the African Development Bank, the European Union, and the IMF. The action plan drawn up with the assistance of our partners is now being implemented. A crucial component of this reform, the transposition of WAEMU directives on public financial management into national legal provisions, is underway. The texts have already been drafted and we expect to complete this transposition in 2011, well before the 2012 deadline established by the WAEMU Commission. We have also named and installed customs and tax collectors. They received training from AFRITAC West, and the start of their work should improve tax administration considerably. In addition, the monitoring of exemptions has been strengthened by a memorandum from the Minister of Economy and Finance aimed at limiting exemptions to only those that are granted by the laws and regulations in force. The new customs code has been submitted to the Office of the Secretary-General of the Government where it is currently under review. It is expected to be adopted by end- 2011 .

\section{Financial sector reform}

23. We remain committed to privatizing the four state-owned banks, although it was not possible for us to issue the call for bids by end-April, as planned in the program (end-April 2011 benchmark). The Privatization Commission established in November 2010 met with privatization advisors in April 2011 to initiate the process intended to identify the strategic 
choices for the privatization and establish a timetable for the necessary steps leading up to the sale of the equity interests of the State. The commission has proposed a privatization strategy for adoption by the Council of Ministers, authorizing the Minister of Economy and Finance to continue the process that will culminate in the effective privatization of the banks. In tandem with the above, the banks' files are being updated by the consulting firms with a view to preparing the data room.

24. In this context, we will launch the process of calling for expressions of interest for the state-owned banks before the meeting of the IMF Executive Board that will examine the report for the $6^{\text {th }}$ review of the ECF. In particular, we will publish a pre-qualification notice in the national press in the form of an advertisement (prior action), to be followed by a notice in the international press. In addition, the receipts from the bank privatizations will be used to repay the domestic debt, in particular the securities issued as part of the bank restructuring process, thereby permitting a significant improvement in public debt dynamics. In collaboration with the WAMU Banking Commission, the government also remains committed to maintaining strict control over the management of these banks until the privatization process has been completed.

25. The process leading to the establishment of a company to recover the nonperforming loans acquired by the government in the context of bank restructuring is progressing, but is taking longer than projected (end-December 2010 benchmark), as a number of legal steps had to be taken before it could effectively become operational. These involve in particular the laws bestowing on the asset recovery company the exceptional privileges and prerogatives of the public authorities with regard to asset recovery. We have decided to create the company by decree, even before the exceptional prerogatives of public authority are vested in it by law, which will make it immediately possible to put in place the human and material resources required for its operation. In fact, the creation of the Togo Asset Recovery Company is now programmed to take place before end-July 2011.

26. We have initiated the process of developing a financial sector development strategy with technical and financial support from our development partners (including Fund staff). The committee entrusted with preparing the strategy was established by order of the Minister of Economy and Finance in February 2011. A national workshop for discussing and validating the strategy is planned for September 2011.

27. The financial and organizational audit of the Togo Retirement Fund (CRT), as well as the actuarial study under the "Financial Sector Governance Project" financed by the World Bank, were finalized on schedule in December 2010 (end-December 2010 benchmark). A workshop to validate the studies was held in March 2011, and the recommendations of the report will be examined by the government.

\section{Real sector}

28. As regards the "one-stop window" at the Autonomous Port of Lomé, the consultant to elaborate the roadmap identifying the steps necessary for its creation (end-September 2010 
benchmark) was recruited with a delay, owing to problems with coordination among the various parties involved in the process. The consultant's conclusions should be available by end-July 2011, enabling the government to examine the recommendations and adopt a roadmap, with a delay compared to initial plans (end-March 2011 benchmark). The government remains committed to completing this measure.

29. With regard to the CEET, we are committed to implementing an electricity tariff-setting policy that takes into account the company's costs and thus contributes to maintaining its financial viability while minimizing fiscal risks. According to our estimates, the rate increase by a weighted average of 20 percent (with an increase of 5-10 percent for the most vulnerable consumers) that was introduced in January 2011, together with a government subsidy of CFAF 3 billion, should ensure that CEET operations break even in 2011. Furthermore, efforts will be made to improve this company's governance.

\section{Borrowing and public debt management strategy}

30. After Togo reached the completion point of the HIPC Initiative, its debt fell to 32 percent of GDP in 2010, not including the contingent liabilities of the various pension funds (CRT, CNSS). In order to further enhance the sustainability of our external debt following the completion point, we will give priority to concessional loans when borrowing externally in accordance with our commitments to our external partners and with the pertinent procedures. Moreover, the government will pursue a prudent fiscal policy in order to maintain debt sustainability in the medium term, and will develop a borrowing strategy consistent with this objective.

31. We are in the process of developing a debt management strategy with technical support from the IMF resident mission; it is intended to define the parameters guiding our choices of debt instruments in the future. In this context, we appreciate the exchanges we have had with IMF staff in the context of Article IV consultations as regards the role that the adoption of fiscal rules could have in terms of supporting a debt management strategy and ensuring debt sustainability in the event of an acceleration of public investment. Moreover, we will continue to enhance our public debt management capacity with support from AFRITAC West and the World Bank.

32. To improve the monitoring of the public debt, state-owned enterprises have begun regularly reporting information on their external borrowing to the Ministry of the Economy and Finance, in order to ensure that this is consistent with the government's external borrowing policy. In addition, a system for systematic communication between state-owned enterprises and the debt management unit at the Ministry has been established for purposes of transmitting monthly information on public debt service obligations.

\section{Conclusion}

33. Togo appreciates the continuing and growing support that its development partners are providing. In particular, cooperation with the IMF has played a decisive role in the significant progress we have made over the past three years. The Togolese authorities are particularly 
pleased by the successful completion of the three-year 2008-2011 program supported by the Extended Credit Facility marked by the completion of this review. We look forward to continuing this fruitful cooperation. To this end, we request the opening of discussions for a new IMF-supported program.

34. As indicated above, the objectives pursued by the ECF-supported program have been achieved, despite the exogenous shocks and administrative capacity constraints. We hope to consolidate the gains made under the program, and, in support of this goal, we have already agreed on indicative benchmarks for the remainder of 2011, in cooperation with the IMF mission. The government reaffirms its commitment to taking any additional measures necessary for ensuring the proper implementation of its budgetary framework. The Togolese authorities intend to consult with the IMF any possible additional measures. We request the completion of the sixth review of the EFC-supported program and disbursement of the seventh loan tranche in the amount of SDR 8.8 million.

35. Finally, the government consents to the publication of this Letter of Intent and its attachments, as well as the IMF Staff Report on the sixth review.

Very truly yours, /s/

Adji Otèth AYASSOR 
Table 1. Togo: Quantitative Performance Criteria and Indicative Targets

September 30, 2010 - December 31, 2011

\begin{tabular}{|c|c|c|c|c|c|c|c|c|c|c|c|c|}
\hline & \multicolumn{4}{|c|}{2010} & \multicolumn{8}{|c|}{$2011^{2}$} \\
\hline & \multicolumn{2}{|c|}{ September } & \multicolumn{2}{|c|}{ December } & \multicolumn{2}{|c|}{ March } & \multicolumn{2}{|c|}{ June } & \multicolumn{2}{|c|}{ September } & \multicolumn{2}{|c|}{ December } \\
\hline & $5^{\text {th }} \operatorname{Rev}^{1}$ & Prelim. $^{2}$ & $5^{\text {th }} \operatorname{Rev}^{1}$ & Prelim. & $5^{\text {th }}$ Rev. $^{1}$ & Prel. & $5^{\text {th }}$ Rev. $^{1}$ & Proj. & $5^{\text {th }}$ Rev. $^{1}$ & Proj. & $5^{\text {th }}$ Rev. $^{1}$ & Proj. \\
\hline & \multicolumn{12}{|c|}{ (In billions of CFA Francs, cumulative from the end of the previous year) } \\
\hline \multicolumn{13}{|l|}{ Performance criteria (for end-June, and end-December 2010; indicative targets otherwise) } \\
\hline Domestic primary fiscal balance (floor) & 26.1 & 46.4 & -1.8 & 34.9 & 5.2 & -5.6 & 20.5 & 4.7 & 16.7 & 2.8 & -6.6 & -26.5 \\
\hline Non-accumulation of external arrears ${ }^{3}$ & 0.0 & 0.0 & 0.0 & 0.0 & 0.0 & 0.0 & 0.0 & 0.0 & 0.0 & 0.0 & 0.0 & 0.0 \\
\hline Net domestic financing (ceiling) & -9.7 & 2.7 & 26.4 & -10.6 & -0.5 & 8.0 & 1.3 & 10.4 & 0.9 & 9.3 & 1.8 & 13.0 \\
\hline Net domestic financing (ceiling adjusted) ${ }^{4}$ & -10.6 & & 36.4 & & & & & & & & & \\
\hline Central governement contracting or guaranteeing of nonconcessional external debt (ceiling) ${ }^{3}$ & 0.0 & 0.0 & 0.0 & 0.0 & 0.0 & 0.0 & 0.0 & 0.0 & 0.0 & 0.0 & 0.0 & 0.0 \\
\hline \multicolumn{13}{|l|}{ Indicative Targets } \\
\hline Total revenue (floor) & 218.0 & 227.9 & 267.6 & 296.9 & 78.5 & 68.2 & 158.1 & 147.7 & 241.0 & 237.1 & 320.2 & 319.8 \\
\hline Domestic payments arrears, changes in stock (ceiling) & & & -46.8 & -36.9 & 0.0 & 0.0 & -13.2 & 0.0 & -13.2 & -6.6 & -13.2 & -13.2 \\
\hline Total domestically financed investment spending (floor) & & & 51.0 & 46.2 & 12.5 & 9.0 & 24.2 & 18.5 & 47.6 & 37.5 & 83.6 & 67.7 \\
\hline Total domestically financed social spending (floor) & & & 87.7 & $86 . \overline{1}^{\top}$ & 16.0 & 16.6 & 42.6 & 44.3 & 74.6 & 77.5 & 106.5 & 110.8 \\
\hline Exceptional Financing & 18.5 & 19.4 & 53.5 & 41.1 & 0.0 & 10.8 & 13.2 & 23.7 & 21.6 & 37.5 & 34.2 & 43.7 \\
\hline
\end{tabular}

${ }^{1}$ Letter of Intent dated November 15, 2010.

${ }^{2}$ Indicative targets.

${ }^{3}$ Continuous performance criterion.

${ }^{4}$ According to the TMU, the ceiling on net domestic financing will be adjusted to offset deviations from projected external program financing, subject to a cap of CFAF 10 billion 
Table 2. Togo: Structural Conditionality for the ECF program in 2010

\begin{tabular}{lll}
\hline \multicolumn{1}{c}{ Measures } & \multicolumn{1}{c}{ Date } & \multicolumn{1}{c}{ Macroeconomic Rationale } \\
\hline $\begin{array}{l}\text { Fiscal governance } \\
\text { Complete implementation of } \\
\text { the strategy for clearing } \\
\text { validated domestic arrears to } \\
\text { private suppliers }\end{array}$ & $\begin{array}{l}\text { Benchmark } \\
\text { end-March }\end{array}$ & $\begin{array}{l}\text { To restore the confidence of suppliers } \\
\text { and make it possible to reduce the } \\
\text { substantial balance of domestic }\end{array}$ \\
& & $\begin{array}{l}\text { payments arrears owed by the } \\
\text { government. To support aggregate } \\
\text { demand in the period of economic } \\
\text { slowdown. }\end{array}$
\end{tabular}

Move towards a single Treasury account by surveying Treasury accounts in the commercial banks and the $\mathrm{BCEAO}$; reduce the number of accounts by at least 30 percent.

Simplify and reduce lag time in the public sector expenditure chain by eliminating redundant control points
Benchmark end-June 2010

Benchmark end-June 2010
Financial sector

Advance on the privatization process for state-owned banks by issuing a final call for bids.
Benchmark endSeptember 2010
Set up the nonperforming loan Benchmark management mechanism or endstructure and its operational support. end2010
To closely monitor Treasury operations, as this is a key element of controlling the government's cash flow operations.
Not met, in expected timeframe but underway. By end-December 2010 , the amount cleared fell short of targets by $28 \%$. Clearance of all arrears has not been possible for reasons beyond the control of authorities, particularly the failure of some creditors to claim settlement.

Met. The survey of Treasury accounts suggested the existence of about 1259 accounts. The number of accounts was reduced to 142 , thus exceeding the minimum reduction of 30 percent.

To increase speed of implementation of Met. The financial auditing was investment projects in the short term and strengthened by the the capacity to absorb foreign aid. implementation of the SIGFIP software that permitted to reduce the delays linked to control from a maximum of 7 to a maximum of 5 weeks. The decree no. 172/MEF/SP-PRPF dated June 28 2010 modified the expenditure chain limiting the treatment of the commitment to the credit administrator and the financial auditor.

To restore confidence in Togo's financial Not met. Delayed to end-April sector, reduce risks of recurrence of macroeconomic instability linked to Togo's large loss-making state-owned banks, promote financial sector development and expand financial intermediation.

To recover a part of the fiscal cost of securitizing NPLs and restore sound financial relationships between banks and firms.

2011. A new privatization law was voted in parliament in October 2010. The call for bids process could start once the privatization commission has examined the different strategic choices and has transmitted its recommendations to the Council of Ministers.

Not met. In the context of the approach followed by the government, the advisors prepared a business plan for the loan recovery corporation. Nevertheless, certain legal measures will have to be taken before establishing the loan recovery corporation.

Benchmark end-

Complete a financial and organizational audit of the December begin an actuarial study of 2010 the institution.

Real Sector

Recruit consultants to elaborate a report on the

Benchmark endrequired steps to create a one-September stop window at the Port

2010 Autonome de Lomé.

im

Foster Togo's competitiveness as a commercial hub and facilitate all administrative procedures for exports and April 2011. The one-stop window at imports and contribute to increase customs revenues.
Establish an overall strategy for clearing Met. The audit and study are part the government's social debt of around 7 of the World Bank financial sector percent of GDP. project.
Approve at the Council of Ministers a new adjustment mechanis $m$ for petroleum product prices.
Benchmark Implement a mechanism that limits fiscal end-November risks by institutionalizing frequent and 2010 automatic adjustments of prices at the pump.
Not met, but done with a delay. the Port Autonome de Lomé is part of a World Bank project aiming to promote regional integration.

Met. A new price adjustment mechanism based on the recommendations of a FAD TA report was adopted. Nevertheless, the mechanism was not effectively applied until June 2011. 
Table 3. Togo: Structural Conditionality for the ECF program in 2011

\begin{tabular}{ccc}
\hline Measures & Date & Sacroeconomic Rationale
\end{tabular}

Fiscal governance

Adopt the draft measures creating a new institutional framework for treasury cash management and putting this framework into operation.

Adopt a strategy that should lead over time to the establishment of a single treasury account after consultation with 2011 the sectoral ministries and development partners.

Financial sector

Make progress in the privatization of public banks by issuing a final call for bids.

Launch the process of calling for expressions of interest for the stateowned banks by publishing a prequalification notice in the national press in the form of an advertisement.

Real Sector

Adopt in the Council of Ministers the roadmap for the creation of a one-stop window at the Port of Lome and start the implementation of first required steps identified by the technical consultants to achieve this objective.
Benchmark Strengthen treasury cash end-January management. 2011

Benchmark end-March 2011

$\begin{array}{ll}\begin{array}{l}\text { Benchmark } \\ \text { end-January } \\ 2011\end{array} & \begin{array}{l}\text { Strengthen treasury cash } \\ \text { management. }\end{array} \\ & \\ \begin{array}{l}\text { Benchmark } \\ \text { end-March }\end{array} & \begin{array}{l}\text { Strengthen treasury cash } \\ \text { management. To closely monitor }\end{array} \\ 2011 & \text { Treasury operations. }\end{array}$

management. To closely monitor Treasury operations.

Met. The ministerial decree
342/MEF/SG/DGTCP of

December 2010 has created a treasury committee.

Not met, but process underway. The authorities are following a consultative process with donors and line ministries to elaborate, adopt and implement the strategy. They are working in close collaboration with AFRITAC for that purpose.

Benchmark Restore confidence in the Togolese end-April 2011 financial sector, reduce the risks of (revised) new macroeconomic instability Not met. The privatization commission held its first meeting in February 2011 and is linked to the large loss-making state- working with the advisors on owned banks and promote financial establishing a calendar and sector development and the making the required strategic expansion of financial intermediation. choices to advance the process.

Prior action for Restore confidence in the Togolese completion of financial sector, reduce the risks of $6^{\text {th }}$ ECF review new macroeconomic instability

Progress ongoing. A call for expressions of interest will be issued before the meeting of the linked to the large loss-making state- IMF Executive Board. owned banks and promote financial sector development and the expansion of financial intermediation.

Benchmark end-March 2011
Foster Togo's competitiveness as a Not met. The recruitment regional commercial hub facilitate the process for the technical administrative procedures for exporting and importing and contribute to increase customs revenues. consultants was longer than expected. Authorities are committed to adopting the roadmap once it is finalized. 


\section{APPENDIX II-UPDATE OF THE DEbT SustainabiLity ANALYSIS (DSA) USING THE LOW- INCOME COUNTRY FRAMEWORK ${ }^{1}$}

The analysis based on the joint IMF-World Bank debt sustainability framework for lowincome countries shows that Togo is at moderate risk of debt distress. After full HIPC assistance, MDRI and beyond HIPC assistance, Togo's external and public debt indicators have improved significantly and are projected remain below the relevant thresholds in the 20-year period under baseline assumptions, thanks to a stable economic and political climate and rehabilitation of key sectors. However, Togo remains vulnerable to certain shocks and could breach the policy-related thresholds for the PV of debt-to-GDP and the PV of debt-to-revenue ratios under some alternative scenarios in the latter years.

\section{A. Introduction}

1. The last joint DSA for Togo was prepared in November 2010 and concluded that Togo was at moderate risk of debt distress after full HIPC assistance, MDRI and beyond HIPC assistance. This debt sustainability analysis (LIC-DSA) for Togo assesses its external and public debt using the forward-looking debt sustainability framework (DSF) for low-income countries. ${ }^{2}$ The outcome of this analysis was in line with previous DSAs, finding generally favorable debt dynamics as a consequence of expected enhancements in the macroeconomic policy framework, notably fiscal discipline and solid implementation of growth-promoting structural reforms. Togo reached the completion point of the HIPC Initiative in December 2010 and was granted debt relief from several multilateral and bilateral creditors. As a result, the nominal debt stock fell from $\$ 1.7$ billion at end-2009 to about $\$ 0.5$ billion at end-2010.

2. The authorities are continuing to make good faith efforts toward reaching agreements with non-Paris Club bilateral creditors, as well as other official and commercial creditors on the provision of debt relief on terms comparable to the relief accorded in the context of the HIPC initiative. At the time of HIPC completion, 88 percent of the multilateral HIPC assistance had already been fully delivered through arrears clearance and

\footnotetext{
${ }^{1}$ This Appendix was prepared by Antonio C. David (AFR).

${ }^{2}$ This DSA update has been prepared by Fund staff using the Debt Sustainability Framework (DSF) for Low Income Countries (see "Applying the Debt Sustainability Framework for Low-Income Countries Post Debt Relief', (http://siteresources.worldbank.org/INTDEBTDEPT/PolicyPapers/21154573/DMSDR1S3149398v1DSFPape rforweb.pdf). Togo's quality of policies and institutions, as measured by the average World Bank's Country Policy and Institutional Assessment (CPIA) for the period 2008-2010 (2.8), places it as a "weak performer". The corresponding indicative thresholds for the external debt indicators are 30 percent for the NPV of debtto-GDP ratio, 100 percent of the debt-to-export ratio, 200 percent for NPV of debt-to-revenue ratio, 15 percent for the debt service-to-exports ratio, and 25 percent for the debt service-to-revenue ratio.
} 
concessional rescheduling of arrears. The World Bank and AfDB have provided their share of debt relief under MDRI after the completion point. Paris Club creditors have also provided relief in December 2010, effectively leading to a 95 percent reduction of Togolese debt towards these creditors. China delivered its share of relief through a 2007 debt cancellation, as did Kuwait through a 2009 loan rescheduling agreement.

3. In the LIC-DSA framework, the present value of Togo's public and publicly guaranteed (PPG) external debt is \$539 million at end-2010, after full delivery of HIPC, MDRI and beyond HIPC assistance. Around 56 percent of this stock of debt is owed to multilateral creditors and the remainder to bilateral and commercial creditors.

\section{B. Baseline Assumptions}

4. The baseline macroeconomic assumptions for the present DSA are the following:

a. Real GDP growth is projected to exceed its estimated long-run growth trend of around 4 percent in the period from 2012 to 2016, largely due to increases in public investment and the fiscal deficit (see below). Subsequently, it will vary around 4 percent, driven by the ongoing rehabilitation of the phosphate and cotton sectors, growth in the agricultural sector (especially food production), an improved investment climate, increased financial intermediation; additional FDI and foreign aid; and growing regional integration, thanks to Togo's strategic geographical location and the role of the port of Lomé. The 4 percent potential growth was estimated based on a population growth rate of 2.5 percent (which reflects the latest available, finalized data) and by building-up sectoral growth rates under the assumptions outlined above and planned growth-enhancing reforms. The estimated potential growth rate exceeds historical rates, which were depressed by the dislocations caused by the protracted social, political, and economic crisis that the country experienced up to the mid-2000s.

b. Public investment is projected to accelerate starting in 2012, reaching 12.6 percent of GDP in 2013 and 2014 and then reverting back to levels close to the ones observed in 2011. About 35 percent of this increase will be financed by loans ( 75 percent of which will be concessional loans). Public investment projects are expected to be mostly directed to infrastructure and will lead GDP growth to increase above its long-term trend for these years.

c. The projections for key commodity prices (oil, cotton, cocoa, and coffee) through 2016 are based on WEO projections of May 2011 and are assumed constant in real terms afterwards.

d. Inflation over the long-term is projected to remain stable at around 2 percent, reflecting sound monetary policy at the regional level. 
e. There is a gradual improvement in the current account deficit over the medium-term, following a deterioration in the early projection years. The deficit remains high, around 5 percent of GDP on average between 2017 and 2031, with higher exports of phosphates, cement and clinker being insufficient to fully compensate for the growth in imports as foreign aid is absorbed and foreign investment increases.

f. The domestic primary fiscal deficit is assumed to stay close to zero ${ }^{3}$ during the projected period, thereby providing a fiscal anchor to ensure fiscal sustainability over the long term. The scaling up of public investment in 2012-14 is projected to lead to a temporary deviation from this fiscal balance

g. FDI and donor flows are expected to increase over the medium-term reflecting improvements in the investment climate and overall governance.

h. External financing is initially mostly on grant ${ }^{4}$ and highly concessional terms, with less concessional financing gradually picking up, leading to a decrease in the grant element of new financing (as shown in Figure 1). Concessional external financing is expected to come largely from Togo's traditional multilateral donors.

\section{External Debt Sustainability Analysis}

\section{Baseline}

\section{Under the baseline scenario, Togo's external debt indicators remain below their} relevant indicative thresholds (Table 1a, Figure 1). The present value (PV) of public and publicly guaranteed (PPG) debt equals to 15.2 percent of GDP in 2011 and remains below the 30 percent threshold until the end of the projected period. Furthermore, both the PV of external debt relative to revenues and exports stay below their respective indicative threshold until 2031. Nevertheless, the three PV ratios (under the baseline scenario) increase significantly over the projected period. This result reflects in part conservative assumptions concerning the outer years, particularly a declining share of concessional loans in new financing, which results in the concessionality of new loans decreasing from 35 percent to close to 5 percent over the period

\footnotetext{
${ }^{3}$ The primary deficit is projected to stay at around 2 percent of GDP over the projection period, with the temporary exception of 2012-14.

${ }^{4}$ The proportion of financing needs covered by grants declines from 80 percent at the beginning of the projection period to less than 50 percent towards the end.
} 
2011 to 2031. In fact, as shown in Table 1a, the contribution of the nominal interest rate to endogenous debt dynamics increases significantly in the post-2016 period $^{5}$.

\section{Alternative Scenarios and Stress Tests}

6. Togo's external debt outlook remains vulnerable to shocks especially toward the end of the projection period (Table 1b, Figure 1). The policy thresholds for two key ratios are breached under the most extreme stress tests. The PV of external debt to GDP indicator deteriorates significantly under the scenario in which new loans are obtained on less favorable terms. In this case, the threshold is breached in 2024. In addition, the PV of debt-to-revenue ratios also surpasses the indicative thresholds at the end of the period under the "less favorable terms" shock.

7. In light of the results from the baseline and alternative scenarios as well as the stress tests, IMF staff concludes that Togo still is at moderate risk of debt distress.

\section{Public Sector Debt Sustainability}

\section{Baseline}

8. The inclusion of Togo's domestic public debt in the analysis emphasizes the vulnerabilities of the baseline scenario (Table 2a, Figure 2). Togo's domestic debt burden reflects years of weak fiscal management and domestic arrears accumulation, as well as the need to recapitalize ailing banks. Much of this debt arose from losses at state-owned enterprises in the past, highlighting the need for further reforms in the governance of these enterprises. Under the baseline scenario, the ratios of total public debt in present value terms are projected to decrease until 2018 before picking up gradually towards the end of the period. These trends are linked to the assumptions regarding the concessionality of financing, with the share of grants gradually falling and increased financing from the regional financial markets. On average, the PV of debt to GDP ratio amounts to around 23.2 percent over the overall period. Given the assumed improvement in the macroeconomic outlook and the cautious debt strategy in the baseline scenario, debt ratios would remain at a reasonable level over the long-run.

\section{Alternative Scenarios and Stress Tests}

9. The evolution of the debt indicators would be highly sensitive to the most extreme shock--a lower growth rate-which would increase the debt level and debt service over the long run. Total public debt dynamics are particularly vulnerable to a growth shock, which would

\footnotetext{
${ }^{5}$ The substantial residual for endogenous debt dynamics presented in Table 1a for 2011 is largely due to exceptional financing, price and exchange rate changes, and debt flow relief. Debt flow relief and price and exchange rate changes also account for over half of the residuals observed in subsequent years.
} 
lead the PV of debt to GDP ratio to break the 30 percent threshold by 2014 (Table 2b, Figure 2). This highlights the importance of a reform agenda that improves the business environment to support foreign investment and growth. ${ }^{6}$

\section{E. Conclusion}

10. The DSA indicates that Togo is at moderate risk of debt distress after reaching the completion point. Under the baseline scenario, the debt ratios remain below the thresholds for the projected period, but under less positive yet realistic alternative scenarios, certain thresholds would be breached in the latter years. These dynamics highlight the vulnerability of the Togolese economy to certain shocks (in particular less favorable terms on new financing) and stress the need for a prudent approach to new borrowing and continuing to seek grant and highly concessional financing to the extent possible, as well as pursuing reforms to improve debt management capacity. The assumptions and conclusions of the DSA were discussed with the authorities, who broadly concurred.

\section{Maintaining a robust external debt outlook will depend on a sustained pick-up in real GDP growth and foreign direct investment, as well as prudent debt management and} solid fiscal performance. The inclusion of Togo's domestic debt in the analysis reinforces the conclusions of the external DSA and stresses the risks to Togo's debt prospects. In this context, it is essential that the Togolese authorities continue current efforts, particularly to strengthen public financial management (especially debt management), restructure the banking system, reform state-owned enterprises, and improve the investment climate hence laying the foundation for accelerating growth.

\footnotetext{
${ }^{6}$ Note the historical scenario assumes that real GDP growth and the primary balance are set at historical averages (over the last 10 years). In the case of Togo, this yields a primary surplus 0.6 percent of GDP for the historical scenario, compared to a primary deficit in the baseline. As a result, gross financing needs and therefore gross new borrowing under the historical scenario are much lower than under the baseline. The large negative new borrowing compared to the baseline, eventually leads to negative PV ratios.
} 
Figure 1. Togo: Indicators of Public and Publicly Guaranteed External Debt under Alternatives Scenarios, 2011-2031 1/
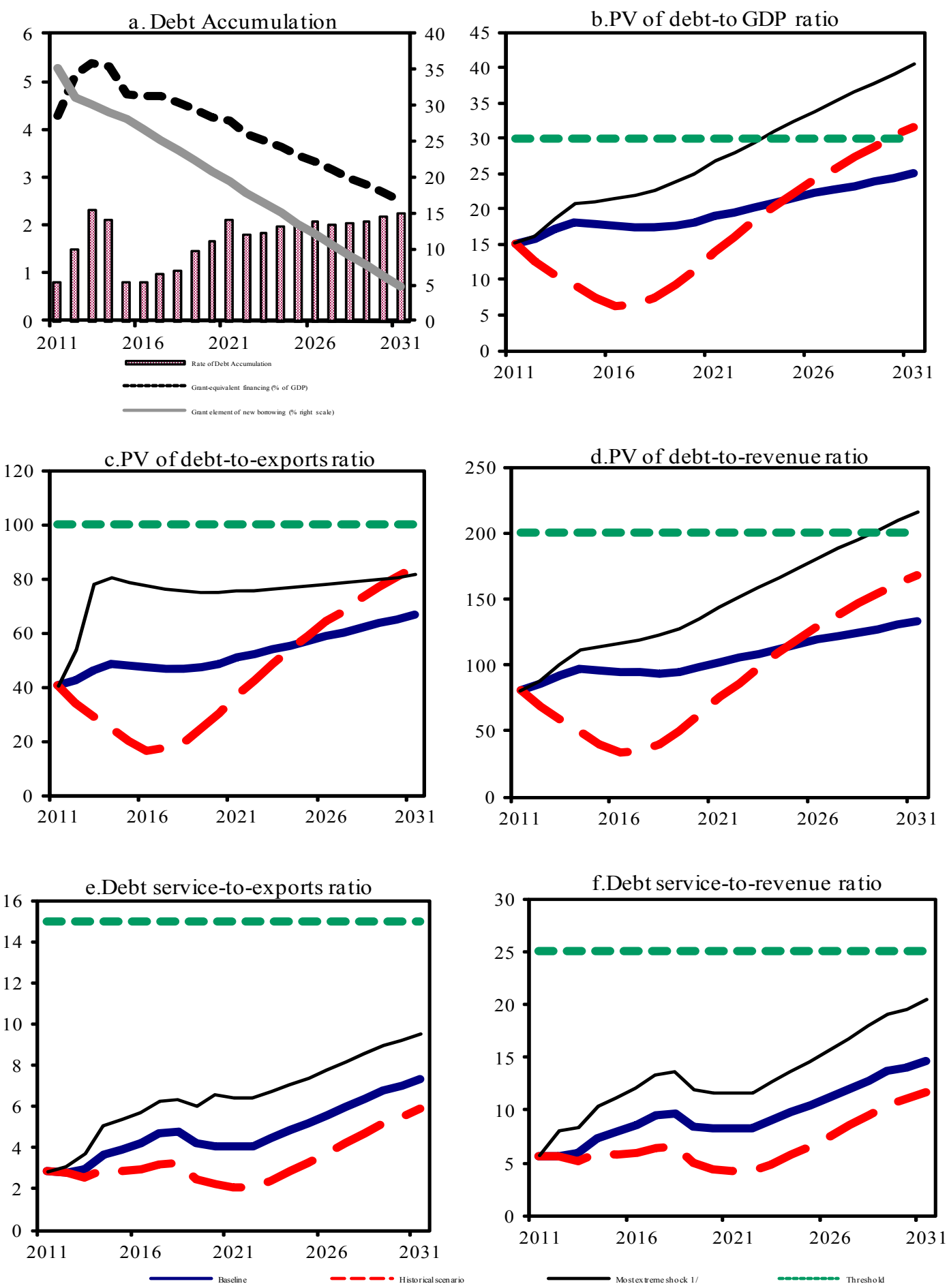

Sources: Country authorities; and staff estimates and projections.

$1 /$ The most extreme stress test is the test that yields the highest ratio in 2021. In figure b. it corresponds to a Terms shock; in c. to a Exports shock; in d. to a Terms shock; in e. to a Exports shock and in figure f. to a One-time depreciation shock 
Figure 2.Togo: Indicators of Public Debt Under Alternative Scenarios, 2011-2031 1/
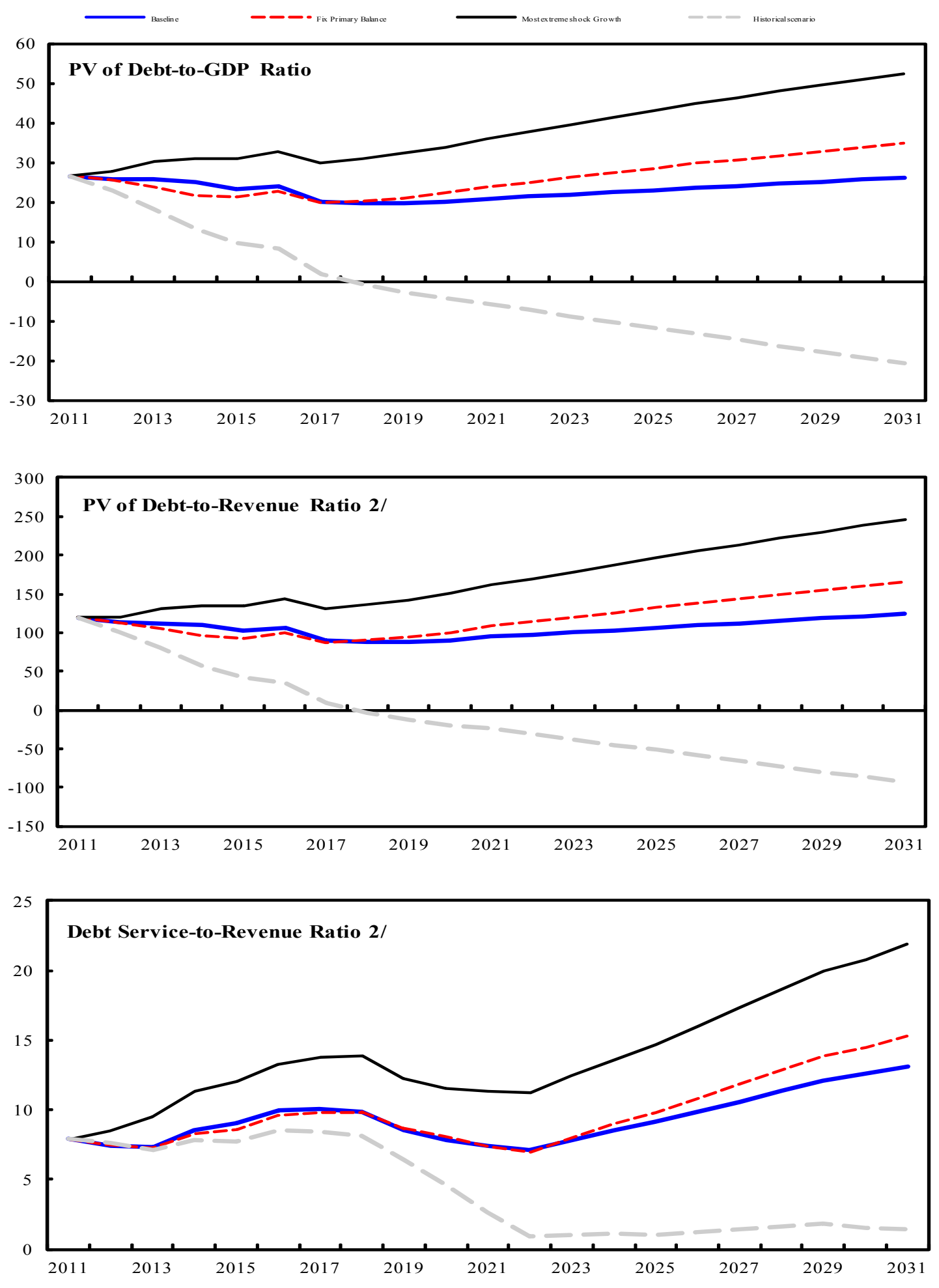

Sources: Country authorities; and staff estimates and projections.

1/ The most extreme stress test is the test that yields the highest ratio in 2021.

2/ Revenues are defined inclusive of grants. 
Table 1a.: External Debt Sustainability Framework, Baseline Scenario, 2008-2031 1/

(In percent of GDP, unless otherwise indicated)

\begin{tabular}{|c|c|c|c|c|c|c|c|c|c|c|c|c|c|c|c|}
\hline & \multicolumn{3}{|c|}{ Actual } & \multirow{2}{*}{\multicolumn{2}{|c|}{$\begin{array}{l}\text { Historical } 0 \text { Standard } \\
\text { Average } 0 \text { Deviation }\end{array}$}} & \multicolumn{6}{|c|}{ Projections } & \multirow{2}{*}{\multicolumn{3}{|c|}{$2011-2016$}} & \multirow{3}{*}{$\begin{array}{r}2017-2031 \\
\text { Average } \\
\end{array}$} \\
\hline & \multirow[b]{2}{*}{2008} & \multirow[b]{2}{*}{2009} & \multirow[b]{2}{*}{2010} & & & \multirow[b]{2}{*}{2011} & \multirow[b]{2}{*}{2012} & \multirow[b]{2}{*}{2013} & & & & & & & \\
\hline & & & & & & & & & 2014 & 2015 & 2016 & Average & 2021 & 2031 & \\
\hline External debt (nominal) 1/ & 61.6 & 53.9 & 19.1 & & & 18.2 & 19.6 & 22.1 & 24.0 & 24.2 & 24.3 & & 27.4 & 33.2 & \\
\hline o/w public and publicly guaranteed (PPG) & 60.9 & 52.7 & 17.2 & & & 16.0 & 17.1 & 19.2 & 20.9 & 20.8 & 20.7 & & 23.3 & 29.5 & \\
\hline Change in external debt & -17.5 & -7.6 & -34.8 & & & -0.9 & 1.5 & 2.5 & 1.9 & 0.2 & 0.1 & & 1.2 & 0.4 & \\
\hline Identified net debt-creating flows & -10.6 & 6.5 & 6.2 & & & 6.0 & 6.3 & 6.3 & 5.7 & 4.8 & 4.2 & & 1.7 & 1.3 & \\
\hline Non-interest current account deficit & 6.4 & 6.3 & 6.8 & 6.4 & 0.5 & 7.3 & 7.8 & 8.0 & 7.8 & 6.9 & 6.3 & & 4.4 & 3.7 & 4.2 \\
\hline Deficit in balance of goods and services & 16.4 & 15.6 & 16.5 & & & 17.7 & 18.6 & 18.9 & 18.4 & 17.2 & 16.5 & & 14.5 & 13.9 & \\
\hline Exports & 35.5 & 36.8 & 37.3 & & & 37.4 & 37.1 & 37.2 & 37.2 & 37.3 & 37.4 & & 37.5 & 37.4 & \\
\hline Imports & 51.9 & 52.5 & 53.8 & & & 55.1 & 55.8 & 56.0 & 55.6 & 54.5 & 53.9 & & 52.0 & 51.3 & \\
\hline Net current transfers (negative $=$ inflow) & -10.1 & -9.6 & -10.2 & -9.6 & 1.7 & -11.0 & -11.5 & -11.5 & -11.3 & -11.0 & -11.0 & & -10.6 & -10.2 & -10.5 \\
\hline o/w official & -1.4 & -1.5 & -2.0 & & & -3.4 & -4.3 & -4.2 & -4.2 & -4.1 & -4.1 & & -3.5 & -2.3 & \\
\hline Other current account flows (negative $=$ net inflow) & 0.0 & 0.3 & 0.4 & & & 0.6 & 0.6 & 0.6 & 0.7 & 0.7 & 0.8 & & 0.4 & 0.0 & \\
\hline Net FDI (negative = inflow) & -1.3 & -0.4 & -0.6 & -2.8 & 1.7 & -1.0 & -1.0 & -1.2 & -1.5 & -1.5 & -1.5 & & -2.2 & -2.0 & -2.1 \\
\hline Endogenous debt dynamics 2/ & -15.8 & 0.6 & 0.1 & & & -0.3 & -0.4 & -0.5 & -0.6 & -0.6 & -0.6 & & -0.5 & -0.4 & \\
\hline Contribution from nominal interest rate & 0.4 & 0.4 & 0.4 & & & 0.3 & 0.3 & 0.3 & 0.4 & 0.4 & 0.4 & & 0.6 & 0.9 & \\
\hline Contribution from real GDP growth & -1.5 & -2.0 & -2.0 & & & -0.6 & -0.8 & -0.9 & -1.0 & -1.0 & -1.0 & & -1.0 & -1.3 & \\
\hline Contribution from price and exchange rate changes & -14.7 & 2.2 & 1.7 & & & $\ldots$ & $\ldots$ & $\ldots$ & $\ldots$ & $\ldots$ & $\ldots$ & & $\ldots$ & $\ldots$ & \\
\hline Residual (3-4) 3/ & -6.9 & -14.2 & -41.1 & & & -7.0 & -4.9 & -3.8 & -3.8 & -4.6 & -4.1 & & -0.5 & -0.9 & \\
\hline $0 /$ w exceptional financing & -2.3 & -2.8 & -2.6 & & & -2.6 & 0.0 & 0.0 & 0.0 & 0.0 & 0.0 & & 0.0 & 0.0 & \\
\hline PV of external debt 4 / & $\ldots$ & $\ldots$ & 18.9 & & & 17.4 & 18.3 & 19.9 & 21.1 & 21.2 & 21.2 & & 23.1 & 28.8 & \\
\hline In percent of exports & $\ldots$ & $\ldots$ & 50.6 & & & 46.4 & 49.2 & 53.6 & 56.8 & 56.7 & 56.6 & & 61.6 & 76.8 & \\
\hline PV of PPG external debt & $\ldots$ & $\ldots$ & 17.0 & & & 15.2 & 15.8 & 17.1 & 18.0 & 17.8 & 17.6 & & 19.0 & 25.0 & \\
\hline In percent of exports & $\ldots$ & $\ldots$ & 45.5 & & & 40.6 & 42.4 & 45.9 & 48.3 & 47.6 & 47.0 & & 50.7 & 66.8 & \\
\hline In percent of government revenues & $\ldots$ & $\ldots$ & 90.1 & & & 80.5 & 85.6 & 92.2 & 97.3 & 96.1 & 94.9 & & 102.6 & 133.6 & \\
\hline Debt service-to-exports ratio (in percent) & 1.2 & 4.6 & 5.1 & & & 2.9 & 2.8 & 2.9 & 3.7 & 3.9 & 4.3 & & 4.1 & 7.3 & \\
\hline PPG debt service-to-exports ratio (in percent) & 1.2 & 4.6 & 5.1 & & & 2.9 & 2.8 & 2.9 & 3.7 & 3.9 & 4.3 & & 4.1 & 7.3 & \\
\hline PPG debt service-to-revenue ratio (in percent) & 2.8 & 10.0 & 10.1 & & & 5.7 & 5.7 & 5.9 & 7.4 & 7.9 & 8.6 & & 8.2 & 14.7 & \\
\hline Total gross financing need (Billions of U.S. dollars) & 0.2 & 0.3 & 0.3 & & & 0.3 & 0.3 & 0.4 & 0.4 & 0.4 & 0.4 & & 0.4 & 0.8 & \\
\hline Non-interest current account deficit that stabilizes debt ratio & 23.9 & 13.9 & 41.6 & & & 8.3 & 6.3 & 5.6 & 5.9 & 6.7 & 6.2 & & 3.2 & 3.2 & \\
\hline Key macroeconomic assumptions & & & & & & & & & & & & & & & \\
\hline Real GDP growth (in percent) & 2.4 & 3.2 & 3.7 & 2.1 & 2.1 & 3.9 & 4.5 & 4.7 & 4.9 & 4.5 & 4.4 & 4.5 & 4.1 & 4.2 & 4.1 \\
\hline GDP deflator in US dollar terms (change in percent) & 22.8 & -3.5 & -3.1 & 7.4 & 8.2 & 11.5 & 2.8 & 1.1 & 1.5 & 1.2 & 1.5 & 3.3 & 2.3 & 2.2 & 2.3 \\
\hline Effective interest rate (percent) $5 /$ & 0.7 & 0.6 & 0.7 & 1.6 & 0.7 & 2.0 & 1.9 & 1.9 & 1.8 & 1.8 & 1.8 & 1.9 & 2.2 & 3.1 & 2.4 \\
\hline Growth of exports of G\&S (US dollar terms, in percent) & 22.2 & 3.4 & 1.9 & 10.9 & 12.9 & 16.2 & 6.6 & 6.1 & 6.6 & 6.1 & 6.0 & 7.9 & 6.7 & 6.4 & 6.5 \\
\hline Growth of imports of G\&S (US dollar terms, in percent) & 26.9 & 0.7 & 3.1 & 12.8 & 17.9 & 18.7 & 8.7 & 6.5 & 5.7 & 3.6 & 4.8 & 8.0 & 6.7 & 6.3 & 6.1 \\
\hline Grant element of new public sector borrowing (in percent) & $\ldots$ & $\ldots$ & $\ldots$ & $\ldots$ & $\ldots$ & 35.2 & 31.1 & 30.1 & 29.1 & 28.1 & 26.7 & 30.0 & 19.4 & 4.8 & 15.0 \\
\hline Government revenues (excluding grants, in percent of GDP) & 15.6 & 16.9 & 18.9 & & & 18.9 & 18.4 & 18.5 & 18.5 & 18.5 & 18.5 & 18.5 & 18.5 & 18.7 & 18.6 \\
\hline Aid flows (in Billions of US dollars) 7/ & 0.0 & 0.1 & 0.1 & & & 0.2 & 0.3 & 0.3 & 0.3 & 0.3 & 0.3 & 0.3 & 0.4 & 0.4 & 0.4 \\
\hline o/w Grants & 0.0 & 0.0 & 0.1 & & & 0.1 & 0.2 & 0.2 & 0.2 & 0.2 & 0.2 & 0.2 & 0.2 & 0.3 & 0.3 \\
\hline o/w Concessional loans & 0.0 & 0.0 & 0.1 & & & 0.1 & 0.1 & 0.1 & 0.1 & 0.1 & 0.1 & 0.1 & 0.1 & 0.1 & 0.1 \\
\hline Grant-equivalent financing (in percent of GDP) 8 / & $\ldots$ & $\ldots$ & $\ldots$ & & & 4.3 & 5.1 & 5.4 & 5.3 & 4.7 & 4.7 & 4.9 & 4.2 & 2.5 & 3.6 \\
\hline Grant-equivalent financing (in percent of external financing) 8/ & $\ldots$ & $\ldots$ & $\ldots$ & & & 72.2 & 73.2 & 66.8 & 66.0 & 75.4 & 73.4 & 71.2 & 59.5 & 39.0 & 55.0 \\
\hline Memorandum items: & & & & & & & & & & & & & & & \\
\hline Nominal GDP (Billions of US dollars) & 3.2 & 3.2 & 3.2 & & & 3.7 & 4.0 & 4.2 & 4.5 & 4.7 & 5.0 & 4.3 & 6.9 & 12.8 & 8.6 \\
\hline Nominal dollar GDP growth & 25.7 & -0.3 & 0.5 & & & 15.9 & 7.4 & 5.9 & 6.5 & 5.7 & 6.0 & 7.9 & 6.5 & 6.5 & 6.5 \\
\hline PV of PPG external debt (in Billions of US dollars) & & & 0.5 & & & 0.6 & 0.6 & 0.7 & 0.8 & 0.8 & 0.9 & 0.7 & 1.3 & 3.2 & 1.8 \\
\hline (PVt-PVt-1)/GDPt-1 (in percent) & & & & & & 0.8 & 1.5 & 2.3 & 2.1 & 0.8 & 0.8 & 1.4 & 2.1 & 2.2 & 1.8 \\
\hline Gross workers' remittances (Billions of US dollars) & 0.2 & 0.3 & 0.3 & & & 0.3 & 0.3 & 0.3 & 0.3 & 0.3 & 0.3 & 0.3 & 0.5 & 1.0 & 0.6 \\
\hline PV of PPG external debt (in percent of GDP + remittances) & $\ldots$ & $\ldots$ & 15.7 & & & 14.1 & 14.7 & 15.9 & 16.8 & 16.6 & 16.4 & 15.8 & 17.7 & 23.2 & 19.4 \\
\hline PV of PPGexternal debt (in percent of exports + remittances) & $\ldots$ & $\ldots$ & 37.4 & & & 33.7 & 35.6 & 38.4 & 40.6 & 40.2 & 39.6 & 38.0 & 42.6 & 55.1 & 46.4 \\
\hline Debt service of PPG external debt (in percent of exports + remittances) & $\ldots$ & $\ldots$ & 4.2 & & & 2.4 & 2.4 & 2.5 & 3.1 & 3.3 & 3.6 & 2.9 & 3.4 & 6.0 & 4.4 \\
\hline
\end{tabular}

Sources: Country authorities; and staff estimates and projections.

$1 /$ Includes both public and private sector external debt.

2/ Derived as $[\mathrm{r}-\mathrm{g}-\rho(1+\mathrm{g})] /(1+\mathrm{g}+\rho+\mathrm{g} \rho)$ times previous period debt ratio, with $\mathrm{r}=$ nominal interest rate; $\mathrm{g}=$ real GDP growth rate, and $\rho=$ growth rate of GDP deflator in U.S. dollar terms.

3/ Includes exceptional financing (i.e., changes in arrears and debt relief); changes in gross foreign assets; and valuation adjustments. For projections also includes contribution from price and exchange rate changes.

4/ Assumes that PV of private sector debt is equivalent to its face value.

5/ Current-year interest payments divided by previous period debt stock.

6/ Historical averages and standard deviations are generally derived over the past 10 years, subject to data availability.

$7 /$ Defined as grants, concessional loans, and debt relief.

8/ Grant-equivalent financing includes grants provided directly to the government and through new borrowing (difference between the face value and the PV of new debt). 
Table 1b.Togo: Sensitivity Analysis for Key Indicators of Public and Publicly Guaranteed External Debt, 2011-2031

(In percent)

Projections

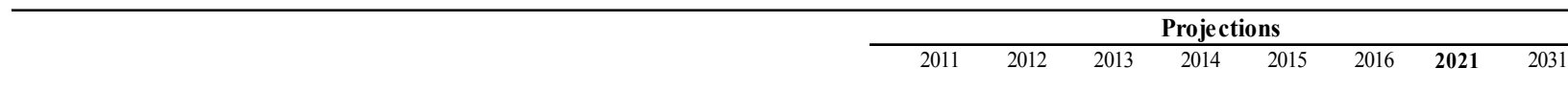

PV of debt-to GDP ratio

Baseline

A. Alternative Scenarios

A1. Key variables at their historical averages in 2011-2031 1/

A2. New public sector loans on less favorable terms in 2011-2031 2

B. Bound Tests

B1. Real GDP growth at historical average minus one standard deviation in 2012-2013 B2. Export value growth at historical average minus one standard deviation in 2012-2013 3/ B3. US dollar GDP deflator at historical average minus one standard deviation in 2012-2013 B4. Net non-debt creating flows at historical average minus one standard deviation in 2012-2013 4/ B5. Combination of B1-B4 using one-half standard deviation shocks

B6. One-time 30 percent nominal depreciation relative to the baseline in $20125 /$
15

$15 \quad 13 \quad 11$

15

16

19

9

21

21

$14 \quad 32$

PV of debt-to-exports ratio

Baseline

41

42

46

48

48

47

51

67

A. Alternative Scenarios

A1. Key variables at their historical averages in 2011-2031 1/

A2. New public sector loans on less favorable terms in 2011-20312

41

B. Bound Tests

B1. Real GDP growth at historical average minus one standard deviation in 2012-2013 B2. Export value growth at historical average minus one standard deviation in 2012-2013 3/

B3. US dollar GDP deflator at historical average minus one standard deviation in 2012-2013

B4. Net non-debt creating flows at historical average minus one standard deviation in 2012-2013 4/

B5. Combination of B1-B4 using one-half standard deviation shocks

B6. One-time 30 percent nominal depreciation relative to the baseline in $20125 /$

\section{PV of debt-to-revenue ratio}

Baseline

81

86

92

92

A. Alternative Scenarios

A1. Key variables at their historical averages in 2011-2031 1/

A2. New public sector loans on less favorable terms in 2011-2031 2

81

68

58

58

50

112

40

14

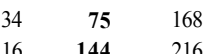

B. Bound Tests

B1. Real GDP growth at historical average minus one standard deviation in 2012-2013 B2. Export value growth at historical average minus one standard deviation in 2012-2013 3/ B3. US dollar GDP deflator at historical average minus one standard deviation in 2012-2013 B4. Net non-debt creating flows at historical average minus one standard deviation in 2012-2013 4/ B5. Combination of B1-B4 using one-half standard deviation shocks

B6. One-time 30 percent nominal depreciation relative to the baseline in 20125 /

$\begin{array}{rrrrrrrr}81 & 89 & 100 & 106 & 104 & 103 & \mathbf{1 1 0} & 143 \\ 81 & 100 & 133 & 137 & 135 & 133 & \mathbf{1 3 0} & 139 \\ 81 & 88 & 97 & 102 & 101 & 99 & \mathbf{1 0 7} & 138 \\ 81 & 102 & 126 & 130 & 128 & 126 & \mathbf{1 2 5} & 137 \\ 81 & 101 & 128 & 133 & 131 & 129 & \mathbf{1 2 8} & 142 \\ 81 & 120 & 129 & 136 & 135 & 133 & \mathbf{1 4 2} & 184\end{array}$


Table 1b.Togo: Sensitivity Analysis for Key Indicators of Public and Publicly Guaranteed External Debt, 2011-2031 (continued)

(In percent)

\section{Debt service-to-exports ratio}

Baseline

\section{A. Alternative Scenarios}

A1. Key variables at their historical averages in 2011-2031 1/

A2. New public sector loans on less favorable terms in 2011-2031 2

\section{B. Bound Tests}

B1. Real GDP growth at historical average minus one standard deviation in 2012-2013

B2. Export value growth at historical average minus one standard deviation in 2012-2013 3/

B3. US dollar GDP deflator at historical average minus one standard deviation in 2012-2013

B4. Net non-debt creating flows at historical average minus one standard deviation in 2012-2013 4/

B5. Combination of B1-B4 using one-half standard deviation shocks

B6. One-time 30 percent nominal depreciation relative to the baseline in 2012 5/

$\begin{array}{rrrrrrrr}3 & 3 & 3 & 4 & 4 & 4 & 4 & 7 \\ & & & & & & & \\ 3 & 3 & 3 & 3 & 3 & 3 & 2 & 6 \\ 3 & 3 & 3 & 4 & 4 & 4 & 4 & 10\end{array}$

\section{Debt service-to-revenue ratio}

Baseline

\section{A. Alternative Scenarios}

A1. Key variables at their historical averages in 2011-2031 1/

A2. New public sector loans on less favorable terms in 2011-20312

$\begin{array}{llllllll}6 & 6 & 5 & 6 & 6 & 6 & 4 & 12 \\ 6 & 6 & 6 & 7 & 8 & 8 & 8 & 19\end{array}$

\section{B. Bound Tests}

B1. Real GDP growth at historical average minus one standard deviation in 2012-2013

B2. Export value growth at historical average minus one standard deviation in 2012-2013 3/

B3. US dollar GDP deflator at historical average minus one standard deviation in 2012-2013

B4. Net non-debt creating flows at historical average minus one standard deviation in 2012-2013 4/

B5. Combination of B1-B4 using one-half standard deviation shocks

B6. One-time 30 percent nominal depreciation relative to the baseline in 20125 /

Memorandum item:

Grant element assumed on residual financing (i.e., financing required above baseline) $6 /$

$\begin{array}{rrrrrrrr}6 & 6 & 6 & 8 & 9 & 9 & \mathbf{9} & 16 \\ 6 & 6 & 6 & 9 & 9 & 10 & \mathbf{1 1} & 16 \\ 6 & 6 & 6 & 8 & 8 & 9 & \mathbf{9} & 15 \\ 6 & 6 & 6 & 8 & 9 & 10 & \mathbf{1 1} & 16 \\ 6 & 6 & 7 & 9 & 9 & 10 & \mathbf{1 1} & 16 \\ 6 & 8 & 8 & 10 & 11 & 12 & \mathbf{1 2} & 20 \\ & & & & & & & \\ 9 & 9 & 9 & 9 & 9 & 9 & 9 & 9\end{array}$

Sources: Country authorities; and staff estimates and projections

1/ Variables include real GDP growth, growth of GDP deflator (in U.S. dollar terms), non-interest current account in percent of GDP, and non-debt creating flows.

$2 /$ Assumes that the interest rate on new borrowing is by 2 percentage points higher than in the baseline., while grace and maturity periods are the same as in the baseline.

3/ Exports values are assumed to remain permanently at the lower level, but the current account as a share of GDP is assumed to return to its baseline level after the shock (implicitly assuming an offsetting adjustment in import levels).

4/ Includes official and private transfers and FDI.

5/ Depreciation is defined as percentage decline in dollar/local currency rate, such that it never exceeds 100 percent.

6/ Applies to all stress scenarios except for A2 (less favorable financing) in which the terms on all new financing are as specified in footnote 2. 
Table 2a.Togo: Public Sector Debt Sustainability Framework, Baseline Scenario, 2008-2031 (In percent of GDP, unless otherwise indicated)

\begin{tabular}{|c|c|c|c|c|c|c|c|c|c|c|c|c|c|c|c|}
\hline & \multicolumn{3}{|c|}{ Actual } & \multirow[b]{2}{*}{ Average } & \multirow[b]{2}{*}{$\begin{array}{c}\text { Standard } \\
\text { Deviation }\end{array}$} & \multicolumn{4}{|l|}{ Estimate } & \multicolumn{6}{|c|}{ Projections } \\
\hline & 2008 & 2009 & 2010 & & & 2011 & 2012 & 2013 & 2014 & 2015 & 2016 & $\begin{array}{l}\text { 2011-16 } \\
\text { Average }\end{array}$ & 2021 & 2031 & $\begin{array}{l}2017-31 \\
\text { Average }\end{array}$ \\
\hline Public sector debt $1 /$ & 83.1 & 67.8 & 32.3 & & & 27.4 & 27.1 & 27.8 & 27.8 & 26.3 & 27.0 & & 25.1 & 30.6 & \\
\hline $0 /$ w foreign-currency denominated & 60.9 & 52.7 & 17.2 & & & 16.0 & 17.1 & 19.2 & 20.9 & 20.8 & 20.7 & & 23.3 & 29.5 & \\
\hline Change in public sector debt & -22.5 & -15.3 & -35.5 & & & -4.9 & -0.3 & 0.7 & 0.0 & -1.5 & 0.7 & & 1.1 & 0.5 & \\
\hline Identified debt-creating flows & -9.3 & -5.7 & 3.3 & & & 0.3 & 2.5 & 3.9 & 3.9 & 1.2 & 1.4 & & 1.2 & 1.3 & \\
\hline Primary deficit & 0.1 & 1.9 & 0.6 & -0.6 & 1.8 & 3.0 & 3.2 & 4.7 & 4.7 & 1.8 & 1.9 & 3.2 & 2.1 & 2.2 & 2.1 \\
\hline Revenue and grants & 17.0 & 18.5 & 20.9 & & & 22.2 & 22.7 & 22.7 & 22.7 & 22.6 & 22.6 & & 22.0 & 21.0 & \\
\hline of which: grants & 1.4 & 1.5 & 2.0 & & & 3.4 & 4.3 & 4.2 & 4.2 & 4.1 & 4.1 & & 3.5 & 2.3 & \\
\hline Primary (noninterest) expenditure & 17.1 & 20.3 & 21.5 & & & 25.2 & 25.9 & 27.4 & 27.4 & 24.5 & 24.5 & & 24.1 & 23.2 & \\
\hline Automatic debt dynamics & -9.4 & -7.6 & 2.7 & & & -2.7 & -0.7 & -0.7 & -0.9 & -0.6 & -0.5 & & -0.9 & -0.9 & \\
\hline Contribution from interest rate/growth differential & -14.7 & -3.1 & -2.6 & & & -1.4 & -0.9 & -0.9 & -1.0 & -0.7 & -0.6 & & -0.9 & -0.9 & \\
\hline of which: contribution from average real interest rate & -12.2 & -0.5 & -0.1 & & & -0.2 & 0.3 & 0.3 & 0.3 & 0.4 & 0.5 & & 0.1 & 0.3 & \\
\hline of which: contribution from real GDP growth & -2.5 & -2.6 & -2.4 & & & -1.2 & -1.2 & -1.2 & -1.3 & -1.2 & -1.1 & & -1.0 & -1.2 & \\
\hline Contribution from real exchange rate depreciation & 5.3 & -4.4 & 5.3 & & & -1.3 & 0.2 & 0.2 & 0.2 & 0.1 & 0.1 & & $\ldots$ & $\ldots$ & \\
\hline Other identified debt-creating flows & 0.0 & 0.0 & 0.0 & & & 0.0 & 0.0 & 0.0 & 0.0 & 0.0 & 0.0 & & 0.0 & 0.0 & \\
\hline Privatization receipts (negative) & 0.0 & 0.0 & 0.0 & & & 0.0 & 0.0 & 0.0 & 0.0 & 0.0 & 0.0 & & 0.0 & 0.0 & \\
\hline Recognition of implicit or contingent liabilities & 0.0 & 0.0 & 0.0 & & & 0.0 & 0.0 & 0.0 & 0.0 & 0.0 & 0.0 & & 0.0 & 0.0 & \\
\hline Debt relief(HIPC and other) & 0.0 & 0.0 & 0.0 & & & 0.0 & 0.0 & 0.0 & 0.0 & 0.0 & 0.0 & & 0.0 & 0.0 & \\
\hline Other (specify, e.g. bank recapitalization) & 0.0 & 0.0 & 0.0 & & & 0.0 & 0.0 & 0.0 & 0.0 & 0.0 & 0.0 & & 0.0 & 0.0 & \\
\hline Residual, including asset changes & -13.2 & -9.7 & -38.8 & & & -5.2 & -2.8 & -3.2 & -3.8 & -2.7 & -0.7 & & -0.1 & -0.8 & \\
\hline \multicolumn{16}{|l|}{ Other Sustainability Indicators } \\
\hline PV of public sector debt & $\ldots$ & $\ldots$ & 32.1 & & & 26.5 & 25.7 & 25.6 & 24.9 & 23.3 & 23.8 & & 20.8 & 26.2 & \\
\hline $0 /$ w foreign-currency denominated & $\ldots$ & $\ldots$ & 17.0 & & & 15.2 & 15.8 & 17.1 & 18.0 & 17.8 & 17.6 & & 19.0 & 25.0 & \\
\hline o/w external & $\ldots$ & $\ldots$ & 17.0 & & & 15.2 & 15.8 & 17.1 & 18.0 & 17.8 & 17.6 & & 19.0 & 25.0 & \\
\hline PV of contingent liabilities (not included in public sector debt) & $\ldots$ & $\ldots$ & $\ldots$ & & & $\ldots$ & $\ldots$ & $\ldots$ & $\ldots$ & $\ldots$ & $\ldots$ & & $\ldots$ & $\ldots$ & \\
\hline Gross financing need $2 /$ & -3.1 & 4.1 & 2.7 & & & 4.7 & 4.9 & 6.3 & 6.7 & 3.9 & 4.1 & & 3.7 & 5.0 & \\
\hline $\mathrm{PV}$ of public sector debt-to-revenue and grants ratio (in percent) & $\ldots$ & $\ldots$ & 153.3 & & & 119.4 & 113.2 & 112.5 & 109.9 & 102.9 & 105.5 & & 94.5 & 124.3 & \\
\hline PV of public sector debt-to-revenue ratio (in percent) & $\cdots$ & $\ldots$ & 169.9 & & & 140.8 & 139.6 & 138.3 & 134.7 & 125.8 & 128.7 & & 112.3 & 139.7 & \\
\hline o/w external $3 /$ & $\ldots$ & $\ldots$ & 90.1 & & & 80.5 & 85.6 & 92.2 & 97.3 & 96.1 & 94.9 & & 102.6 & 133.6 & \\
\hline Debt service-to-revenue and grants ratio (in percent) 4/ & -18.8 & 12.2 & 10.4 & & & 7.9 & 7.5 & 7.3 & 8.6 & 9.0 & 10.0 & & 7.4 & 13.2 & \\
\hline Debt service-to-revenue ratio (in percent) 4/ & -20.5 & 13.3 & 11.5 & & & 9.3 & 9.2 & 9.0 & 10.5 & 11.1 & 12.1 & & 8.8 & 14.8 & \\
\hline Primary deficit that stabilizes the debt-to-GDP ratio & 22.6 & 17.2 & 36.1 & & & 7.9 & 3.5 & 4.0 & 4.7 & 3.3 & 1.2 & & 1.0 & 1.7 & \\
\hline \multicolumn{16}{|l|}{ Key macroeconomic and fiscal assumptions } \\
\hline Real GDP growth (in percent) & 2.4 & 3.2 & 3.7 & 2.1 & 2.1 & 3.9 & 4.5 & 4.7 & 4.9 & 4.5 & 4.4 & 4.5 & 4.1 & 4.2 & 4.1 \\
\hline Average nominal interest rate on forex debt (in percent) & 0.7 & 0.6 & 0.7 & 1.6 & 0.7 & 2.1 & 2.1 & 2.0 & 2.0 & 1.9 & 1.9 & 2.0 & 2.4 & $3.3^{r}$ & 2.6 \\
\hline Average real interest rate on domestic debt (in percent) & -11.3 & 1.0 & 2.6 & -1.0 & 6.6 & 0.7 & 3.3 & 3.7 & 4.5 & 6.9 & $10.3^{\mathrm{r}}$ & 4.9 & 3.2 & $0.0^{\top}$ & 2.8 \\
\hline Real exchange rate depreciation (in percent, + indicates depreciation) & 7.8 & -7.6 & 10.5 & -3.3 & 10.6 & -8.1 & $\ldots$ & $\ldots$ & $\ldots$ & $\ldots$ & $\ldots$ & $\ldots$ & $\ldots$ & $\ldots$ & .. \\
\hline Inflation rate (GDP deflator, in percent) & 14.4 & 1.9 & 1.8 & 3.5 & 6.4 & 3.8 & 2.7 & 2.4 & 2.6 & 2.0 & 2.2 & 2.6 & 2.3 & 2.2 & 2.3 \\
\hline Growth of real primary spending (deflated by GDP deflator, in percent) & -0.1 & 0.2 & 0.1 & 0.1 & 0.1 & 0.2 & 0.1 & 0.1 & 0.0 & -0.1 & 0.0 & 0.1 & 0.0 & 0.0 & 0.0 \\
\hline Grant element of new external borrowing (in percent) & $\ldots$ & $\ldots$ & $\ldots$ & $\ldots$ & $\ldots$ & 35.2 & 31.1 & 30.1 & 29.1 & 28.1 & 26.7 & 30.0 & 19.4 & 4.8 & ... \\
\hline
\end{tabular}

Sources: Country authorities; and staff estimates and projections.

1 / [Indicate coverage of public sector, e.g., general government or nonfinancial public sector. Also whether net or gross debt is used.]

2/ Gross financing need is defined as the primary deficit plus debt service plus the stock of short-term debt at the end of the last period.

3 / Revenues excluding grants

4/ Debt service is defined as the sum of interest and amortization of medium and long-term debt.

5/Historical averages and standard deviations are generally derived over the past 10 years, subject to data availability. 
Table 2b.Togo: Sensitivity Analysis for Key Indicators of Public Debt 2011-2031

PV of Debt-to-GDP Ratio

Baseline

A. Alternative scenarios

A1. Real GDP growth and primary balance are at historical averages

A2. Primary balance is unchanged from 2011

A3. Permanently lower GDP growth 1/

\section{B. Bound tests}

B1. Real GDP growth is at historical average minus one standard deviations in 2012-2013

B2. Primary balance is at historical average minus one standard deviations in 2012-2013

B3. Combination of B1-B2 using one half standard deviation shocks

B4. One-time 30 percent real depreciation in 2012

B5. 10 percent of GDP increase in other debt-creating flows in 2012

Projections

\begin{tabular}{llllllll}
2011 & 2012 & 2013 & 2014 & 2015 & 2016 & 2021 & 2031 \\
\hline
\end{tabular}

\section{PV of Debt-to-Revenue Ratio 2/}

\section{Baseline}

\section{A. Alternative scenarios}

A1. Real GDP growth and primary balance are at historical averages

A2. Primary balance is unchanged from 2011

A3. Permanently lower GDP growth 1/

$\begin{array}{rrrrrrrr}27 & 26 & 26 & 25 & 23 & 24 & 21 & 26 \\ & & & & & & & \\ 27 & 23 & 18 & 13 & 10 & 8 & -6 & -21 \\ 27 & 25 & 24 & 22 & 21 & 23 & 24 & 35 \\ 27 & 26 & 26 & 26 & 24 & 25 & 26 & 42\end{array}$

\section{B. Bound tests}

B1. Real GDP growth is at historical average minus one standard deviations in 2012-2013

B2. Primary balance is at historical average minus one standard deviations in 2012-2013

B3. Combination of B1-B2 using one half standard deviation shocks

B4. One-time 30 percent real depreciation in 2012

B5. 10 percent of GDP increase in other debt-creating flows in 2012

$\begin{array}{llllllll}27 & 28 & 30 & 31 & 31 & 33 & 36 & 52 \\ 27 & 24 & 21 & 20 & 19 & 19 & 17 & 23 \\ 27 & 24 & 20 & 21 & 21 & 22 & 25 & 41 \\ 27 & 32 & 31 & 30 & 28 & 28 & 24 & 31 \\ 27 & 35 & 34 & 33 & 32 & 32 & 28 & 31\end{array}$

$\begin{array}{llllllll}119 & 113 & 112 & 110 & 103 & 106 & 94 & 124\end{array}$

$\begin{array}{rrrrrrrr}119 & 100 & 80 & 57 & 41 & 36 & -24 & -93 \\ 119 & 112 & 105 & 95 & 93 & 100 & 108 & 165\end{array}$

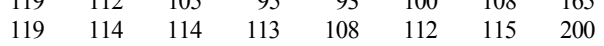

Debt Service-to-Revenue Ratio 2/

\section{Baseline}

$\begin{array}{rrrrrrrr}119 & 120 & 131 & 135 & 134 & 143 & 161 & 247 \\ 119 & 105 & 91 & 89 & 82 & 85 & 76 & 111 \\ 119 & 104 & 88 & 92 & 90 & 98 & 113 & 193 \\ 119 & 141 & 137 & 132 & 124 & 126 & 111 & 147 \\ 119 & 153 & 151 & 148 & 140 & 142 & 127 & 149\end{array}$

\section{A. Alternative scenarios}

A1. Real GDP growth and primary balance are at historical averages

A2. Primary balance is unchanged from 2011

A3. Permanently lower GDP growth 1/

$\begin{array}{rrrrrrrr}8 & 8 & 7 & 8 & 8 & 8 & 3 & 1 \\ 8 & 7 & 7 & 8 & 9 & 10 & 7 & 15 \\ 8 & 7 & 7 & 9 & 9 & 10 & 8 & 17\end{array}$

\section{B. Bound tests}

B1. Real GDP growth is at historical average minus one standard deviations in 2012-2013

B2. Primary balance is at historical average minus one standard deviations in 2012-2013

B3. Combination of B1-B2 using one half standard deviation shocks

B4. One-time 30 percent real depreciation in 2012

B5. 10 percent of GDP increase in other debt-creating flows in 2012

$\begin{array}{rrrrrrrr}8 & 8 & 8 & 10 & 10 & 11 & 10 & 21 \\ 8 & 7 & 7 & 8 & 8 & 9 & 6 & 12 \\ 8 & 8 & 7 & 8 & 9 & 10 & 7 & 17 \\ 8 & 8 & 9 & 11 & 12 & 13 & 11 & 22 \\ 8 & 7 & 9 & 10 & 10 & 11 & 10 & 16\end{array}$

Sources: Country authorities; and staff estimates and projections.

1/ Assumes that real GDP growth is at baseline minus one standard deviation divided by the square root of the length of the projection period.

2/ Revenues are defined inclusive of grants. 


\section{APPENDIX III-Linking Public InVESTMent, GROWTH AND DEBT SUSTAINABILITY In Togo ${ }^{1}$}

1. This appendix presents a brief summary of preliminary results of an application to the Togolese economy of a dynamic general equilibrium model that analyzes the links between public investment, economic growth and debt sustainability. ${ }^{2}$ The model constructed by Buffie and others (2011) aims to complement the standard IMF-World Bank debt sustainability framework for low-income countries. ${ }^{3}$ In this open-economy model, public capital is highly productive and complementary to private capital, generating positive medium and long-run effects from increases in public investment. Nevertheless, additional public investment does not necessarily lead to a growth takeoff that would ensure debt sustainability by itself. The model also allows us to analyze the risks associated with different financing options for the surge in public investment (namely, concessional loans, external commercial loans and domestic borrowing) and quantifies the fiscal adjustments required over the medium-term in order to ensure debt sustainability.

\section{The model's parameters were calibrated to match data available for the Togolese}

economy. But where Togo-specific estimates were not available, the parameters were set to fit a "generic" low income country, as described in Buffie and others (2011). Regarding crucial parameters, the return on infrastructure investment was set at 25 percent based on the literature regarding infrastructure investment in Africa; user fees are assumed to allow recouping about 50 percent of recurring costs for infrastructure projects; ${ }^{4}$ and we also assume a trend growth rate of 4 percent. In the baseline model, public investment is not fully efficient, implying that every dollar invested by the government creates less than one dollar in public "effective" capital. The relevant parameter is set at 0.5 based on the estimates of Pritchett (2000) for sub-Saharan Africa. In fact, the available evidence suggests relatively modest public investment efficiency in Togo,

\footnotetext{
${ }^{1}$ This Appendix was prepared by Antonio C. David (AFR) based on joint-work with Michal Andrle (RES), Raphael Espinoza (SPR), Marshall Mills (AFR) and Felipe Zanna (RES).

${ }^{2}$ The full application of the model to the Togolese economy is a collaborative effort between RES, SPR and AFR and is presented in a mimeo by Andrle, David, Espinoza, Mills and Zanna (2011), which is intended for eventual publication as an IMF Working Paper.

${ }^{3}$ Note that the increase in public investment simulated in the main experiment of this model application is significantly larger than the one assumed in the medium-term macroeconomic framework presented in the Staff Report and in the DSA presented in Appendix II. The investment scale-up considered in the main model simulations is in part an illustration of the large infrastructure needs of a low-income country such as Togo and serves the purpose of quantifying the resulting policy trade-offs of ambitious efforts to meet these needs, given a set of assumptions. As discussed briefly in this appendix, we also experiment with less ambitious paths for increases in investment (see draft Working Paper for additional details) and one of these paths is close to the public investment increases assumed in the macro framework (namely the prudent investment scale-up scenario).

${ }^{4}$ This is in line with the average estimate for sub-Saharan African countries, as discussed in Briceno-Garmendia et al. (2008).
} 
as the country ranks in the bottom quartile of sub-Saharan African countries in the distribution of the index for public investment management quality (PIMI) developed by Dabla-Norris and others (2011). This index comprises measures of the quality of appraisal, selection, management and evaluation of public investment projects. $^{5}$

\section{The first main experiment undertaken is an increase in public investment that is} heavily frontloaded in the early years. Public investment goes from an initial value of 8 percent of GDP to a peak of 17.6 percent of GDP after three years. In the baseline, the authorities are assumed to finance the investment surge using available concessional external financing, and through domestic taxation when this is not sufficient. There are no limits imposed on the size or speed of fiscal adjustment and therefore tax rates increase to finance this additional investment (beyond what is financed by concessional loans). Because taxes are distortionary in the model, this will lead to some crowding-out of private investment. The assumptions regarding the returns on public capital and the efficiency of public investment affect significantly the longrun effects of the public investment increase, as illustrated in Table 1.

\section{In the medium-run, access to external commercial borrowing can allow for some smoothing of the fiscal adjustment, while still maintaining favorable debt dynamics, but} there are important risks. The trajectories for key variables over a 30 year period are plotted in Figure 1. The fact that the government has access to additional external non-concessional resources allows for less difficult fiscal adjustments compared to the case in which only concessional loans are available, as indicated in the first panel of the Figure. This in turn affects the paths of consumption and investment. In this case, there is no crowding-out of private investment and consumption is also smoother. Nevertheless, since commercial debt is more expensive, the risks to debt sustainability are higher. But even if the adjustment is smoother, the size of the required tax increases is large ${ }^{6}$ and possibly not feasible or desirable for a low-income country, like Togo.

\footnotetext{
${ }^{5}$ Nevertheless, it is important to note that there is no direct mapping between the PIMI index (which is a relative measure) and the efficiency parameter discussed in the model. The results presented here are broadly unchanged when one sets the efficiency parameter at 0.4 , but when efficiency is extremely low (for example when $\mathrm{s}=0.2$ ), the results are significantly altered.

${ }^{6}$ The results presented in the Figure are based on a specification where consumption tax rates are not capped; but, if taxes are capped at 22 percent of GDP, debt would follow an explosive path.
} 
Table 1: Long-run effects under different choices of parameters

\begin{tabular}{lccc}
\hline & Baseline & Alternative 1 & Alternative 2 \\
\cline { 2 - 4 } & $\mathrm{R}=0.25, \mathrm{~s}=0.5$ & $\mathrm{R}=0.35, \mathrm{~s}=0.8$ & $\mathrm{R}=0.10, \mathrm{~s}=0.2$ \\
\hline Taxes (\%) & 22.3 & 20.1 & 24.4 \\
Crowding-in coefficient & 0.8 & 1.0 & 0.4 \\
Public Effective Capital & 48.1 & 76.9 & 19.2 \\
Private Capital & 8.7 & 18.1 & 1.7 \\
Real GDP & 8.5 & 18.0 & 1.5 \\
Real Wages & 8.4 & 17.9 & 1.5 \\
Consumption & 3.6 & 12.5 & -3.0 \\
Output in tradable sector & 7.6 & 17.6 & 0.2 \\
Output in Non-tradable sector & 10.3 & 18.7 & 4.1 \\
\hline The & & &
\end{tabular}

The effects are measured in percent change between the steady states, except for taxes and the crowdingin coefficient. The crowding-in coefficient is defined as the change in private capital following a change in public capital $(\Delta \mathrm{k} / \Delta \mathrm{z})$.

\section{More modest increases in public investment would require more feasible tax} adjustments over the medium-run. When we consider model simulations of less ambitious investment scale-ups, notably increases that are 30 percent and 70 percent smaller than the base case, the resulting increases in consumption tax rates that are required for debt sustainability are smaller. Consumption taxes would increase by 2.5 percent and 1 percent, respectively, when compared to initial values. ${ }^{7}$ In fact, increases in revenue collection of this magnitude may be feasible without raising rates if the efficiency of tax collection is improved sufficiently.

\section{The pace of the acceleration in public investment also matters, particularly in the} face of inefficiencies in investment. In alternative experiments, we also assessed the relative merits of frontloaded increases in infrastructure investment in the presence of significant inefficiencies in public investment compared to more gradual accelerations in investment. In the latter case, some improvement in terms of public investment efficiency is expected to occur over time, for example, because of the implementation of reforms to governance and public financial management or through some form of learning by doing in terms of administrative capacity. The results of model simulations indicate that there are welfare gains from following the gradual approach, as the present discounted value of consumption is higher under the gradual approach compared to the frontloaded investment path.

\footnotetext{
${ }^{7}$ These figures refer to "feasible" caps on consumption tax rates i.e. caps that would not generate unfavorable debt dynamics in the model where commercial external borrowing is available to smooth the fiscal adjustment.
} 
Figure 1. Model Simulations Allowing for Commercial External

Debt Compared to Model with Concessional Borrowing

Exclusively
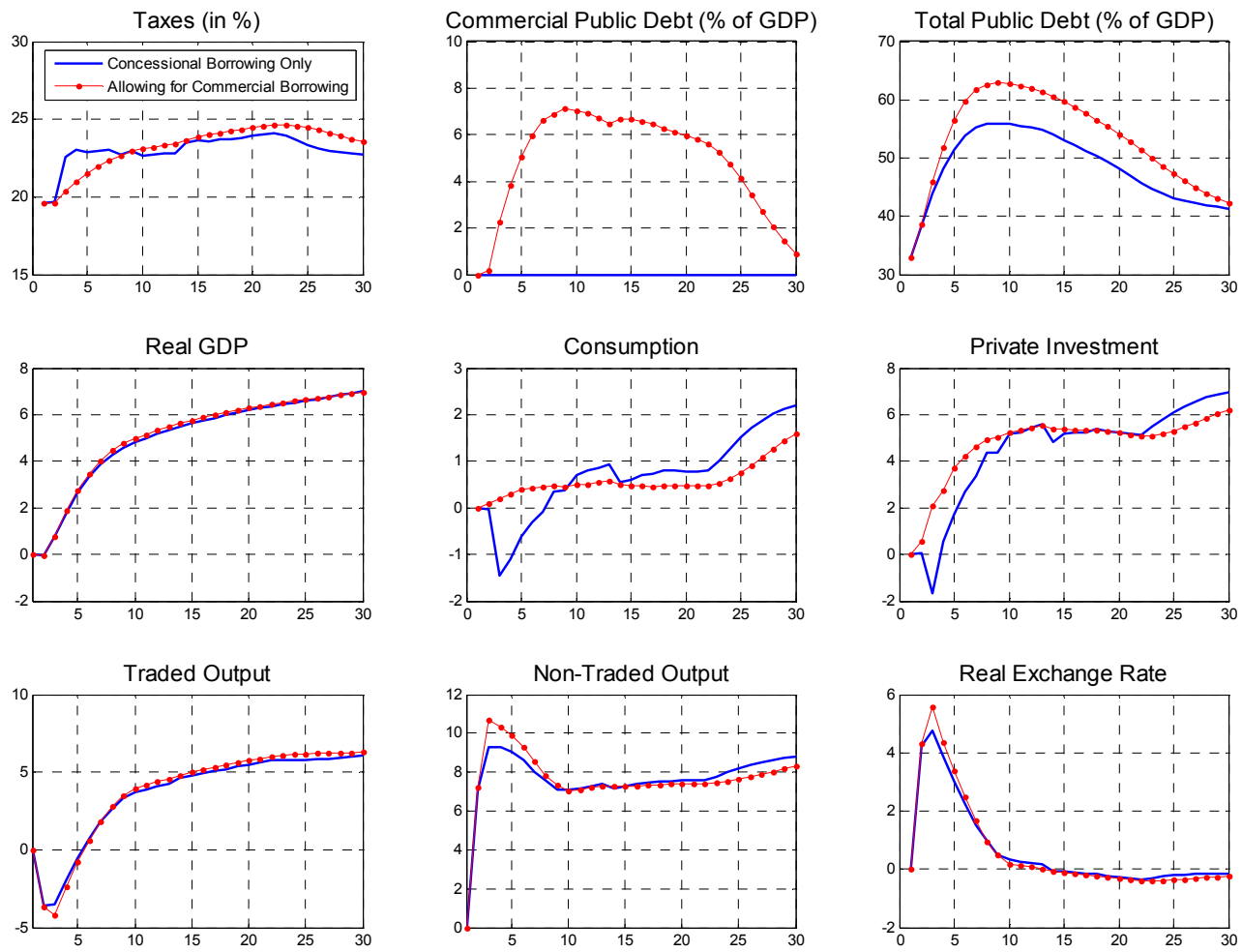

Note: Real GDP, consumption and private investment are expressed as percentage deviations from initial steady-state. The burden of fiscal adjustment falls exclusively on taxes in this specification.

\section{Overall, the results suggest that even if the macroeconomic implications of public} investment scale-ups can be favorable in the long run under certain conditions, the transition is likely to be challenging. These conditions include a good rate of return on infrastructure projects ( 25 percent); efficiency in public investment at the level of a typical subSaharan African country (50 cents in public capital for every dollar spent); and increased efforts in revenue collection, particularly on consumption taxes, possibly by a combination of increases in tax rates and improvement in efficiency in collection of these taxes. In this context, the model serves as a tool to quantify the trade-offs involved in a frontloaded increase in public investment, considering the impact of public capital on output as well as inefficiencies in public investment. It is important to bear in mind that the conclusions obtained in the application of the model are sensitive to the set of assumptions made. Therefore, the results of the model should be used with care. This framework constitutes one of several useful policy tools to be utilized in an ongoing, iterative fashion to guide assessments regarding the feasibility of investment surges. 


\section{The model-based analysis of debt sustainability in Togo confirms that the country remains vulnerable to adverse debt dynamics over the medium term under certain} scenarios. A very large increase in public investment would have positive macroeconomic effects in the long-run, in particular higher output and consumption than would have been the case otherwise. Nevertheless, it would require unrealistic increases in tax rates to ensure debt sustainability. In light of these results, Togolese authorities could envisage more modest increases in public investment and/or alternatively would have to obtain additional external resources in the form of grants to finance such increases in investment. The question also arises of the extent to which increases in investment in infrastructure should be frontloaded, even in the presence of significant inefficiencies in public investment, as opposed to proceeding more gradually to reap more benefits from improving the efficiency of investment through reforms to governance and learning by doing. At the same time, given the enormous infrastructure needs, especially in light of bottlenecks to growth, a sense of urgency in investment from policymakers is understandable. This model allows policymakers to quantify the investment-growth nexus (i.e., the positive impact of investment on growth and hence debt sustainability). At the same time, we believe that, based on preliminary results of this application, policy makers should scale up infrastructure investment in a prudent, progressive approach, as progress is achieved in public financial management and investment capacity, more ambitious investment paths could be considered. 


\section{References}

Andrle, M., David, A. C., Espinoza, R., Mills, M. and Zanna, L. F. (2011) "You May Delay but Time Will Not: Public Investment Surges, Growth and Debt Sustainability in Togo", IMF, mimeo, June.

Briceno-Garmendia, C.; Smits, K.: and Foster, V. (2008) "Financing Public Infrastructure in Sub-Saharan Africa: Patterns and Emerging Issues" AICD Background Paper 15, World Bank, Washington, DC.

Buffie, E.; Berg, A.; Patillo, C.; Portillo, R.; and Zanna, L. F. (2011) "Public Investment, Growth and Debt Sustainability: Putting Together the Pieces", IMF, mimeo, March.

Dabla-Norris, E., Brumby, J., Kyobe, A., Mills, Z. and Papageorgiou, C. (2011) "Investing in Public Investment: An Index of Public Investment Efficiency" IMF Working Paper WP/11/37, February, Washington, DC.

Pritchett (2000) "The tyranny of Concepts: CUDIE (Cumulated, Depreciated, Investment Effort) is not Capital" Journal of Economic Growth, 5, 361-384. 


\section{APPENDIX IV-TOGO: A FRAMEWORK FOR GROWTH-SUPPORTING FISCAL RULES ${ }^{1}$}

1. This appendix explores the issues the Togolese authorities may wish to consider in establishing a formal fiscal rule, should they decide to pursue this option. Medium-term fiscal policy would likely benefit from carefully designed policy rules, in the context of relaxed financing constraints following debt relief and plans for a temporary scaling up. The commitment to a rule could anchor expectations that public finances will be sustainable, provided the public supports the rule and there is pre-announced mechanism to adjust for deviations. It may also help shape public debates.

2. The current juncture in Togo may be appropriate to begin reflection on the introduction of a rule-based fiscal framework. Fiscal consolidation is one of the achievements of the ECF-supported program. Rules-based frameworks have typically been adopted to lock-in successful fiscal adjustments, as prior consolidation makes the introduction of the rule more credible; otherwise, building its credibility in the eyes of the public often takes years of discipline.

3. A fiscal rule is a permanent constraint on fiscal policy discretion, typically defined in terms of an indicator of overall fiscal performance (Kopits and Symansky, 1998). Fiscal rules are a mechanism to place durable constraints on fiscal discretion through numerical and procedural limits on budgetary aggregates. They entail several elements: the specification of numerical targets or ceilings on easy-to-monitor fiscal aggregates; procedures to deal with deviations from targets; incentives for the authorities to abide by the rule; and effective monitoring and enforcement procedures.

\section{Well-designed — and implemented_rules can strengthen a government's} accountability and enhance the quality, transparency, and credibility of fiscal policy. However, while fiscal rules can be a useful tool to improve fiscal management, their prerequisites (adequate public financial management systems and strong government ownership) suggest that they are not appropriate for every country to adopt. In some cases, the introduction of a rule can even have negative consequences for the conduct of fiscal policy. This may happen because the pre-conditions specified above are not met, or because the rule that may be desirable in the long-run may be counterproductive in the short-run.

5. In the case of Togo, one main long-term anchor is currently clear-the WAEMU basic fiscal balance. The basic balance is appropriate as a criterion of fiscal convergence to sustain the monetary union. The value of fiscal convergence criteria has been highlighted by the recent experience of other monetary unions. The question for the Togolese authorities to consider is the following: does the basic fiscal balance fully meet their objectives by itself? In particular,

\footnotetext{
${ }^{1}$ This Appendix was prepared by Edgardo Ruggiero (AFR).
} 
the chosen anchor should respect not only the WAEMU fiscal convergence objectives, but also the Togolese authorities' other fiscal and macroeconomic policy objectives. How important is it to achieve a target level of public investment to bridge the infrastructure gap or to be able to conduct counter-cyclical fiscal policy? How important is it to raise social spending with the objective to achieve the Millennium Development Goals?

6. By excluding foreign-financed investment spending, the basic fiscal balance already gives considerable room to increase investment spending. However, because of this exclusion, the anchor on the basic balance does not establish a reasonably good check on debt accumulation, thus not necessarily ensuring fiscal sustainability by itself.

7. The exclusion of foreign financed-investment spending from the basic fiscal balance, combined with experience elsewhere, would argue for complementing the anchor on the basic balance with an anchor on total debt. In this context, it is arguable that the current WAEMU convergence criterion that total debt should be lower than 70 percent of GDP appears too high for a country at Togo's level of capacity, particularly given its new debt situation following HIPC debt relief. Togo's Country Policy and Institutional Assessment (CPIA) index was 2.4 in 2009, classifying Togo as having low institutional and policy design capacity in the context of the Debt Sustainability Framework (IMF and IDA, 2010). For countries with a CPIA below 3.25, the DSF sets a threshold of the NPV of external debt to GDP of 30 percent, above which the country is considered at risk of debt distress.

8. In choosing an appropriately safe level of debt, the authorities should be mindful of liquidity risk. While membership to WAEMU provides some protection against excessive external debt denominated in a foreign currency, Togo's current low debt and cash management capacity, as well as low PFM scores in general, would argue in favor of setting - for purely domestic policy purposes - a lower debt threshold than the 70 percent prescribed by WAEMU. Another argument in favor of targeting a lower debt ratio is that Togo is also exposed to a revenue risk, as it has a low revenue-to-GDP ratio, a factor associated to several cases of debt distress.

9. Once the Togolese authorities have chosen a reasonably low debt-to-GDP ratio, it is possible to derive a primary deficit that would stabilize public debt at that specific level over the long run. ${ }^{2}$

\footnotetext{
${ }^{2}$ The primary deficit (revenue minus expenditures plus interest payments) is suggested here as a possible computational rule, because it is closely related to debt sustainability. Under current WAEMU rules, the convergence criterion on the deficit is the basic fiscal balance, which is defined by WAEMU Act 04/99 as total revenue minus current expenditure and domestically financed capital spending. For reference, the key fiscal target under the ECF-supported program is the domestic primary balance, which is defined as revenue minus expenditures plus foreign-financed spending and interest payments.
} 
10. The authorities could also safeguard domestic investment by excluding it from the deficit anchor, at least temporarily. In this way they would be applying a "golden-rule" type anchor. The advantage of this rule is that a key policy objective of the authorities (i.e., raising investment spending to close the infrastructure gap) would be safeguarded. However, this anchor has three main drawbacks. First, it is not directly linked to debt accumulation. It is thus important to complement it with an anchor on total debt. Second, the exclusion of any category of spending, be it domestic investment or social spending, comes at a cost, as the rule becomes less transparent. There is a clear trade-off between the simplicity of the rule and the need to protect investment spending by excluding it from the rule. Third, the exclusion of any category of spending establishes the strong incentive for government to engage in creative accounting, shifting allocation from a monitored category to an excluded category. Thus, this exclusion could be pursued only when supported by improvements in public financial management, in particular in the classification, reporting, and monitoring of government operations.

\section{The experience of WAEMU countries highlights how the constraint on the basic} fiscal balance has not provided good guidance for fiscal policy in the presence of output and terms of trade shocks. In a currency union, the design of rules needs to be cognizant of the needed flexibility in fiscal policy, as it remains the only available tool for macroeconomic stabilization.

\section{Thus, the Togolese authorities should consider superimposing time frame}

regulations, or rules, on the fiscal anchor, to make the rule more flexible. A time rule defines the number of years over which the anchor needs to be respected, thus allowing for the temporary departure from the anchor within the limits defined by the time rule. This gives medium-term, counter-cyclical flexibility to the rule and to policymakers, thus considerably enhancing the likelihood of rule's success. For example, the time rule might specify that the basic balance target should be respected, cumulatively, in the course of an agreed number of years, say, for example 5 years. In other words, the sum of fiscal balances over the 5-year period has to be equal to or above zero. Under this time rule, a government can chose, on any given year, a level of budget deficit/surplus, provided that the sum of the fiscal balances over the five year period respects the anchor. Figure 1 below shows three examples of possible fiscal balance path under this time rule. Many more are of course possible. ${ }^{3}$ Thus, the government has considerably more medium-term flexibility on how to counter exogenous shocks.

\footnotetext{
${ }^{3}$ Since the sum of all fiscal balances in the 5-year period has to equal zero, any fiscal path chosen under this particular time rule produces no change in the stock of debt by the end of the period.
} 
Figure 1: Time Rule 1: Deficit averages zero over the time period Assume time-rule $=5 y$ rs

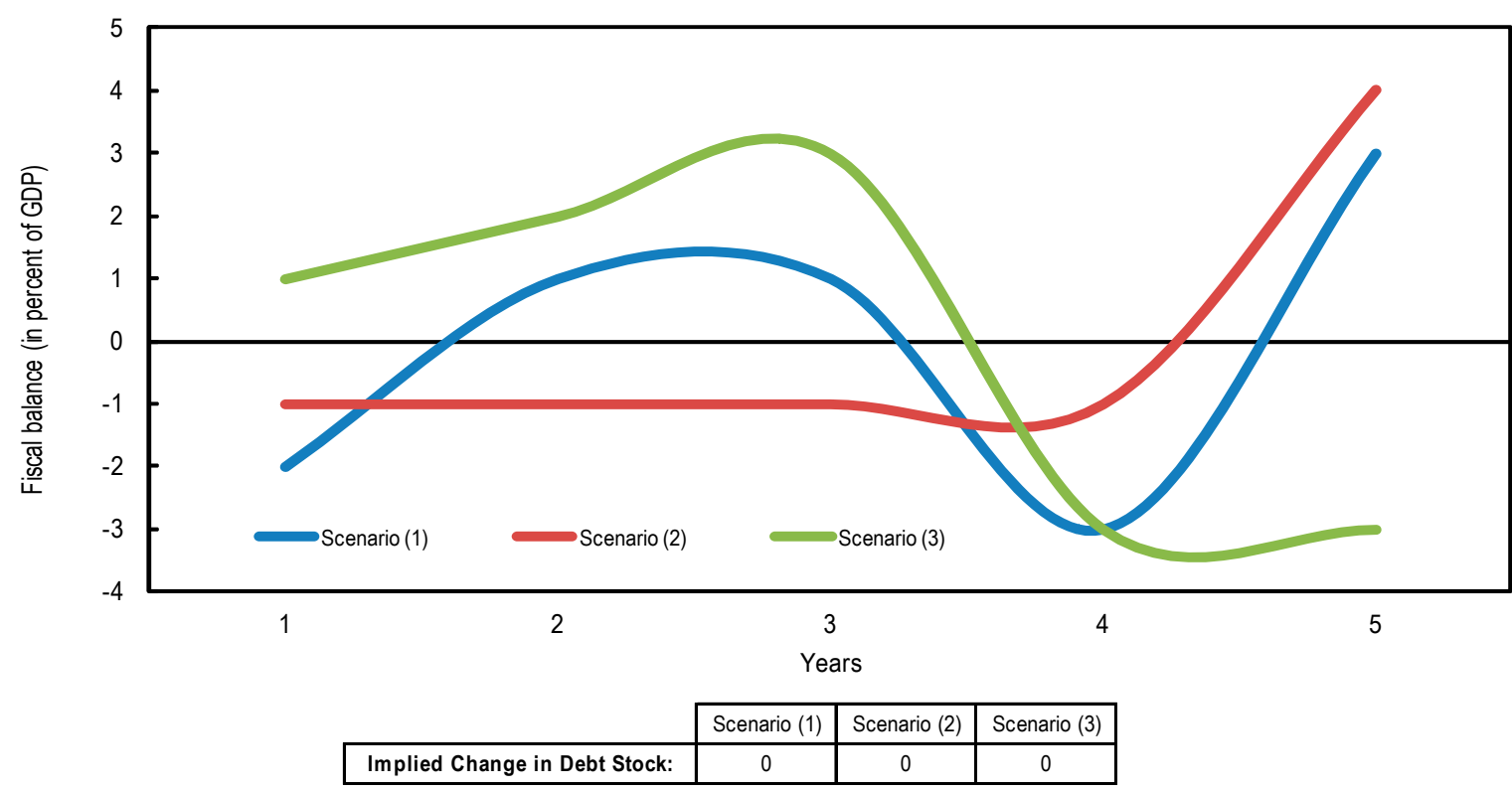

13. To enhance flexibility further, the authorities could also adopt clearly defined escape clauses and buffers. An escape clause addresses major shocks (those shocks the country just cannot absorb without abandoning the fiscal rule), or deals with the budgetary impact of major structural reforms (e.g., civil service reforms). The buffers instead are built in the rule to pre-empt the impact of minor shocks and economic fluctuations.

14. However, the mere introduction of a fiscal rule would not guarantee success, unless the authorities establish costs to breaking the rule that are higher than the benefits of respecting it. An essential element of a rule is that it has to be perceived as costly for the government to break it. The cost of deviating from the rule can be set through formal sanctions or through the adverse reputational impact of reneging to a formal commitment. Sanctions are rarely a chosen avenue, as they require effective autonomous enforcement. Formal procedures raising the reputational cost and/or mandating corrective actions are preferable. The authorities could consider raising the reputational costs in various ways, including an obligation to publicly explain deviations and what the government intends to do to return within the path prescribed by the rule.

\section{Fiscal Responsibility Laws (FRLs) are useful in this context, and the authorities} could consider exploring the possibility of a basic FRL in the medium-term. These are usually focused on government accountability. In a rule-based framework, FRLs often clarify under what conditions the government can depart from the anchor prescribed by the rule and how to return to it (escape clauses and buffers). 
16. A key ingredient to the success of rule-based frameworks is ownership. It is thus important to introduce a rule-based framework for fiscal policies only if there is broad-based support for the authorities for the advantages associated to subjecting fiscal policies decisions to rules. International experience shows that this is indeed the case, provided the rules are tailored to the economic conditions and specific policy objectives of the country, including allowing for flexibility to respond to shocks. Adequate public financial management is another important element to consider; on this point, Togo has made considerable progress, although continued progress is highly desirable. 


\section{References}

Kopits, G. and S. Symansky, 1998, “Fiscal Policy Rules,” IMF Occasional Paper n 162, International Monetary Fund (Washington D.C).

International Monetary Fund and International Development Association, 2010, "Staff Guidance Note on the Application of the Joint Bank-Fund Debt Sustainability Framework for Low Income Countries (Washington D.C.) 
INTERNATIONAL MONETARY FUND

TOGO

Staff Report for the 2011 Article IV Consultation and Sixth Review Under the Extended Credit Facility Arrangement-Informational Annex

Prepared by the African Department

(In consultation with other departments)

Approved by Michael Atingi-Ego and Thomas Dorsey

July 7, 2011

Contents

Page

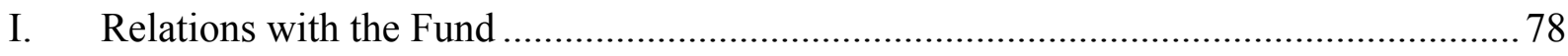

II. Joint Management Action Plan .............................................................................. 86

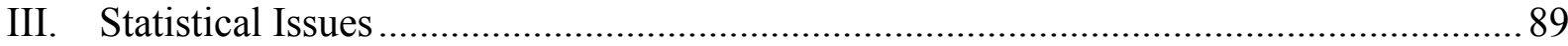




\section{APPENDIX I-RELATIONS WITH THE FUND}

(as of May 31, 2011)

I. Membership Status: Joined August 1, 1962; Article VIII

II. General Resources Account:

Quota

Fund holdings of currency

Reserve Position

III. SDR Department:

Net cumulative allocation

Holdings

IV. Outstanding Purchases and Loans:

ECF Arrangements

V. Financial Arrangements:

Type

$\mathrm{ECF}^{1}$

$\mathrm{ECF}^{1}$

$\mathrm{ECF}^{1}$

${ }^{1}$ Formerly PRGF.

Apr 21, 2008

Sep 16, 1994

May 31, 1989
SDR million

73.40

72.99

0.42

SDR million

70.33

59.32

SDR million

86.45

Expiration

Date

Aug 31, 2011

Jun 29, 1998

May 19, 1993
Amount Approved (SDR million)

95.41

65.16

46.08
Percent of quota

100.00

99.44

0.57

Percent of allocation

100.00

84.35

Percent of quota

117.78

Amount Drawn

(SDR million)

86.61

54.30

38.40

VI. Projected Payments to the Fund ${ }^{2}$

(SDR million; based on existing use of resources and present holdings of SDRs)

\begin{tabular}{|c|c|c|c|c|c|}
\hline & & & oming & & \\
\hline & 2011 & 2012 & 2013 & 2014 & 2015 \\
\hline Principal & & & 1.17 & 8.04 & 11.60 \\
\hline Charges/Interest & 0.03 & 0.27 & 0.27 & 0.26 & 0.24 \\
\hline Total & $\underline{0.03}$ & $\underline{0.27}$ & $\underline{1.44}$ & $\underline{8.31}$ & $\underline{11.84}$ \\
\hline
\end{tabular}

\footnotetext{
${ }^{2}$ When a member has overdue financial obligations outstanding for more than three months, the amount of such arrears will be shown in this section.
} 


\section{Implementation of HIPC Initiative:}

I. Commitment of HIPC assistance $\quad$ Framework

Decision point data

Nov 2008

Assistance committed

By all creditors (US\$ Million)

282.00

Of which: IMF assistance (US\$ million)

0.32

(SDR equivalent in millions)

0.22

Completion point date

Dec 2010

II. Disbursement of IMF assistance (SDR Million)

Assistance disbursed to the member

0.22

Interim assistance

0.08

Completion point balance

0.14

Additional disbursement of interest income ${ }^{2}$

0.01

Total disbursements

0.22

${ }^{1}$ Assistance committed under the original framework is expressed in net present value (NPV) terms at the completion point, and assistance committed under the enhanced framework is expressed in NPV terms at the decision point. Hence these two amounts can not be added.

${ }^{2}$ Under the enhanced framework, an additional disbursement is made at the completion point corresponding to interest income earned on the amount committed at the decision point but not disbursed during the interim period.

\section{Exchange Arrangement}

Togo is a member of the West African Economic and Monetary Union (WAEMU) and has no separate legal tender. The exchange system, common to all WAEMU countries, is free of restrictions on the making of payments and transfers for current international transactions. The union's common currency, the CFA franc, is pegged to the euro at a rate of

CFAF $655.957=$ EUR 1, consistent with the official conversions rate of the French franc to the euro and the previous fixed rate of the CFA franc to the French franc of CFAF $100=\mathrm{F} 1$. On April 28, 2006, the rate of the CFA franc in terms of SDR was CFAF 769.68= SDR 1.0. Effective January 1, 2007, the exchange arrangement of the WAEMU countries has been reclassified to the category of conventional pegged arrangement from the category of exchange arrangement with no separate legal tender. The new classification is based on the behavior of the common currency, whereas the previous classification was based on the lack of a separate legal tender. The new classification thus only reflects a definitional change, and is not based on a judgment that there has been a substantive change in the exchange regime or other policies of the currency union or its members

\section{Safeguards Assessments}

The Central Bank of West African States (BCEAO) is the common central bank of the countries of the West African Economic and Monetary Union, which includes Togo. The most recent safeguards assessment of the BCEAO was completed on March 1, 2010. The 2010 update 
assessment found that the BCEAO continues to have controls in place at the operational level. The overall governance framework needed nonetheless to be strengthened by the addition of an audit committee to ensure that the Board of Directors exercises appropriate oversight over the control structure, including the audit mechanisms and financial statements. The Institutional Reform of the WAMU and the BCEAO completed after the approval of the safeguards report stipulated creation of the Audit Committee, which should now start working. Efforts to implement fully the International Financial Reporting Standards reporting framework should also be pursued.

\section{Article IV Consultation}

Togo is on the standard 24-month Article IV consultation cycle. The Executive Board completed the last 2009 Article IV consultation on April 21, 2009.

\section{Technical Assistance}

\section{A. AFRITAC West}

\section{Customs Administration}

\begin{tabular}{|l|l|}
\hline Dates & Objectives \\
\hline $\begin{array}{l}\text { September-October } \\
2007\end{array}$ & Launching Sydonia++ \\
\hline March-April 2008 & $\begin{array}{l}\text { Assessment of control methods at Customs offices; optimization custom } \\
\text { controls; and reinforcement of controls after customs clearance. }\end{array}$ \\
\hline March 2009 & Reinforcement of customs clearance procedures. \\
\hline June 2010 & $\begin{array}{l}\text { Evaluation of planned short-term actions, and continuous support of } \\
\text { AFRITAC West in modernizing the Customs Administration and reinforcing } \\
\text { its capacity in generating revenue and simplifying procedures. }\end{array}$ \\
\hline
\end{tabular}


Tax Administration:

\begin{tabular}{|l|l|}
\hline Dates & Objectives \\
\hline October 2005 & Follow-up progress in strengthening tax administration. \\
\hline May-June 2006 & $\begin{array}{l}\text { Assessment of tax administration reforms; modernization of tax } \\
\text { administration. }\end{array}$ \\
\hline November 2006 & Regional workshop on ethics in tax and customs administration. \\
\hline April 2007 & Help DGG to increase tax base and improve control services. \\
\hline June-July 2007 & Support the elaboration of a research strategy and fiscal control. \\
\hline January 2008 & $\begin{array}{l}\text { Assessment of 2007 reports of Directorate General of Taxation; assist in } \\
\text { 2008 fiscal control reports; improve reimbursement of VAT credits. }\end{array}$ \\
\hline September-October & $\begin{array}{l}\text { Evaluation of FAD's recommendations made after the December 2006 } \\
\text { mission; (2) a proposal for an action plan to increase the tax base; and (3) } \\
\text { reinforcement of the capacity of the task force in charge of reforming the } \\
\text { DCG. }\end{array}$ \\
\hline April 2009 & $\begin{array}{l}\text { Evaluation of progress made in applying recommendations of previous } \\
\text { FAD and AFRITAC West missions; and the reinforcement of research } \\
\text { activities to combat tax fraud. }\end{array}$ \\
\hline April-May 2009 & $\begin{array}{l}\text { Visit to the DCG to help authorities elaborate a strategy to increase the tax } \\
\text { base based on intelligence research. }\end{array}$ \\
\hline September 2009 & $\begin{array}{l}\text { Assist the tax administration in applying measures to reinforce fiscal } \\
\text { operations. }\end{array}$ \\
\hline May 2010 & $\begin{array}{l}\text { Take stock of progress made in applying the different modernization axes; } \\
\text { gather information on the different projects which are to be completed in } \\
\text { the short- and medium-term; and indentify TA needs that could be provided } \\
\text { by AFRITAC West in the next three years. }\end{array}$ \\
\hline $\begin{array}{l}\text { Reinforcement of the operations of SMEs unit in order to help better } \\
\text { manage the medium enterprises segment in the short- and medium-term and } \\
\text { their fiscal return. }\end{array}$ \\
\hline
\end{tabular}

\section{Public Expenditure Management:}

\begin{tabular}{|l|l|}
\hline Dates & Objectives \\
\hline $\begin{array}{l}\text { September-October } \\
2007\end{array}$ & $\begin{array}{l}\text { Support of public accounting management at the Directorate General of } \\
\text { Treasury and Public Accounting. }\end{array}$ \\
\hline May 2008 & $\begin{array}{l}\text { Assist the public debt unit to validate debt data and prepare documentation } \\
\text { required by the Paris Club. }\end{array}$ \\
\hline August 2008 & $\begin{array}{l}\text { Assist the General Secretariat of the Ministry of Economy and Finance and his } \\
\text { staff to prepare draft texts on the duties, organization and functioning of the } \\
\text { IGF, and to draft a procedure manual summaries, which should allow this unit } \\
\text { to be operational upon the appointment or recruitment of inspectors of finance. }\end{array}$ \\
\hline $\begin{array}{l}\text { October-November } \\
2008\end{array}$ & $\begin{array}{l}\text { Implementation of accounting reforms and especially the completion of } \\
\text { clearance related work of consolidated balances of treasury accounts. }\end{array}$ \\
\hline
\end{tabular}




\begin{tabular}{|c|c|}
\hline February 2009 & Review of the Treasury Accounting System \\
\hline April-May 2009 & $\begin{array}{l}\text { Assist the Treasury and Public Accounting unit in the implementation of } \\
\text { accounting reforms, mainly the finalization of the clearance of accounts and } \\
\text { ensuring consistency of accounts with balances of Treasury accounts. }\end{array}$ \\
\hline May-June 2009 & $\begin{array}{l}\text { Train inspectors on the use of finance manual audit procedures and conduct } \\
\text { audits and help establish a methodology for structuring and audit reports and a } \\
\text { methodology for developing the control program and audit. }\end{array}$ \\
\hline May-June 2009 & $\begin{array}{l}\text { Support authorities' efforts to strengthen public financial management and } \\
\text { restructuring of Treasury. }\end{array}$ \\
\hline October 2009 & $\begin{array}{l}\text { Identify the main weaknesses in implementation of SIGFIP and propose } \\
\text { SIGFIP, along a set timetable, the improvements needed to minimize risks and } \\
\text { optimize the management of public expenditure; assess the user needs of the } \\
\text { entire expenditure chain, the output of SIGFIP and provide technical advice; and } \\
\text { revise the action plan for the short, medium and long term, to improve the } \\
\text { accounting system and reporting of annual accounts, together with other donors. }\end{array}$ \\
\hline January 2010 & $\begin{array}{l}\text { Train forty administration officials to elaborate and present laws and regulations } \\
\text { to assess the implementation of the various recommendations of previous } \\
\text { missions to redress the balance of government accounts. }\end{array}$ \\
\hline May-June 2010 & $\begin{array}{l}\text { Assess the progress of the action plan proposed in } 2009 \text { and support the } \\
\text { authorities in the consolidation and management planning of the government } \\
\text { treasury. }\end{array}$ \\
\hline October 2010 & $\begin{array}{l}\text { Train accountants in financial administrations and the Treasury on accounting of } \\
\text { financial administrations. }\end{array}$ \\
\hline February 2010 & $\begin{array}{l}\text { Regional workshop on "Managing the State Treasury: Planning and Coverage } \\
\text { Needs of State Treasury on the government securities market. }\end{array}$ \\
\hline May 2011 & $\begin{array}{l}\text { Strengthen the capacity of the authorities with regard to cash management; } \\
\text { assess the progress of the action plan proposed by the previous mission in June } \\
2009 \text { and to support ongoing initiatives for consolidation and management } \\
\text { planning of the government treasury. }\end{array}$ \\
\hline
\end{tabular}

\section{Debt Management and Financial Markets:}

\begin{tabular}{|l|l|}
\hline Dates & Objectives \\
\hline May-June 2007 & $\begin{array}{l}\text { Analyze contracts with principal donors; improve software applications for } \\
\text { debt management at DPD. }\end{array}$ \\
\hline November 2007 & Verify data base; help prepare analysis of debt sustainability. \\
\hline September 2008 & $\begin{array}{l}\text { Help managers to enforce the terms of debt relief so that the database is } \\
\text { exhaustive. }\end{array}$ \\
\hline May 2009 & Strengthen the management capacity of domestic debt. \\
\hline July 2009 & $\begin{array}{l}\text { Help treasury officials to integrate the operations of debt in the expenditure } \\
\text { circuit and to examine the data needs of the debt of other administrations. }\end{array}$ \\
\hline
\end{tabular}




\begin{tabular}{|l|l|}
\hline $\begin{array}{l}\text { October-November } \\
2009\end{array}$ & Evaluation of methods of issuing government bonds. \\
\hline April 2010 & $\begin{array}{l}\text { Build capacity in data management of the debt to have all the information } \\
\text { necessary for the completion point }\end{array}$ \\
\hline October 2010 & $\begin{array}{l}\text { Support the conduct of analysis needed in view of reaching the completion } \\
\text { point under the HIPC initiative for Togo. }\end{array}$ \\
\hline December 2010 & $\begin{array}{l}\text { Workshop to identify the types of analysis and to develop appropriate tools } \\
\text { for their implementation, in view of negotiation and mobilization of HIPC } \\
\text { assistance. }\end{array}$ \\
\hline
\end{tabular}

\section{Macroeconomic Statistics}

\begin{tabular}{|c|c|}
\hline Dates & Objectives \\
\hline September 2007 & Regional workshop on 2001 public finance manual. \\
\hline October 2007 & $\begin{array}{l}\text { Support the services in charge of the preparation of the tables of the } \\
\text { government's financial operations (TOFE in French) }\end{array}$ \\
\hline June 2008 & $\begin{array}{l}\text { Regional Training Seminar on "Analytical Framework Manual on } \\
\text { Government Finance Statistics (GFS) 2001, changes from that of the GFSM } \\
\text { 1986." }\end{array}$ \\
\hline July 2008 & $\begin{array}{l}\text { Continued assistance for improving the production of government finance } \\
\text { statistics, including TOFE (Monitoring Mission). }\end{array}$ \\
\hline October 2008 & $\begin{array}{l}\text { Examine the table used to calculate the aggregate public finances by the } \\
\text { Treasury and help develop a methodological note on the elaboration of the } \\
\text { TOFE to facilitate reading the spreadsheet data. }\end{array}$ \\
\hline April 2009 & Continue training on methods and practices of the TOFE. \\
\hline May 2009 & $\begin{array}{l}\text { Continue training for the production and dissemination of government } \\
\text { finance statistics according to the classifications of the Manual of } \\
\text { Government Finance Statistics } 2001 \text { (GFSM). }\end{array}$ \\
\hline April 2011 & $\begin{array}{l}\text { Strengthen the capacity of the authorities on Directive No. } \\
10 / 2009 / \mathrm{CM} / \mathrm{UEMOA} \text { on the TOFE. }\end{array}$ \\
\hline
\end{tabular}

\section{Real Sector Statistics}

\begin{tabular}{|l|l|}
\hline Dates & Objectives \\
\hline December 2007 & $\begin{array}{l}\text { Assist Directorate General of Statistics and National Accounts in the } \\
\text { implementation of the 1993 National Accounting System (SCN 93in French). }\end{array}$ \\
\hline March 2009 & $\begin{array}{l}\text { Support the General Directorate of Statistics and National Accounts (DSCN) } \\
\text { for the rebuilding of a national accounting system consistent with the System } \\
\text { of National Accounts 1993 (SNA 93). }\end{array}$ \\
\hline $\begin{array}{l}\text { August-September } \\
\begin{array}{l}\text { October-November } \\
\text { 2009 }\end{array}\end{array}$ & $\begin{array}{l}\text { Support the General Directorate of Statistics and National Accounts (DSCN) } \\
\text { in its work of implementing the System of National Accounts 1993 (SNA } \\
\text { March-April 2010. } \\
\begin{array}{l}\text { May 2010 } \\
\text { February-March 2011 }\end{array}\end{array}$ \\
\hline
\end{tabular}




\section{Microfinance Supervision:}

\begin{tabular}{|l|l|}
\hline Dates & Objectives \\
\hline January 2007 & Support inspection missions in microfinance institutions. \\
\hline April 2007 & Regional workshop on exchange of information. \\
\hline November 2007 & Support and monitor unit on money control. \\
\hline January-February 2008 & Support and monitor unit on inspection methods. \\
\hline September 2008 & Support and monitor unit on organizational strengthening. \\
\hline $\begin{array}{l}\text { November-December } \\
2008\end{array}$ & Support and monitor unit on inspection methods. \\
\hline March 2009 & Support and monitor unit on delegated supervision. \\
\hline June 2009 & Support and monitor unit on remote controls. \\
\hline $\begin{array}{l}\text { September-October } \\
2009\end{array}$ & Support and monitor unit on inspection methods. \\
\hline
\end{tabular}

\section{Banking Supervision and Restructuring:}

\begin{tabular}{|l|l|}
\hline May 2010 & $\begin{array}{l}\text { Assess needs for technical assistance to implement the proposed restructuring } \\
\text { of the banking sector, the establishment of a mechanism Recovery of toxic } \\
\text { debts transferred to the State and to develop a strategy for financial sector } \\
\text { development. }\end{array}$ \\
\hline June 2010 & $\begin{array}{l}\text { Validation workshop of the draft report of the consortium Mazars-Marccus } \\
\text { under the feasibility study for the implementation of a mechanism for debt } \\
\text { collection and facilitation of trading of securities resulting from the } \\
\text { restructuring of banking Togo. }\end{array}$ \\
\hline December 2010 & $\begin{array}{l}\text { Assist authorities in assessing the situation of public banks and the } \\
\text { establishment of the recovery mechanism non performing loans acquired by } \\
\text { the State. }\end{array}$ \\
\hline March 2011 & $\begin{array}{l}\text { Provide advice on the process of restructuring the public banking sector on } \\
\text { the establishment of a mechanism to recover outstanding non performing } \\
\text { loans and on the progress of the draft strategy preparation of financial sector } \\
\text { development. }\end{array}$ \\
\hline
\end{tabular}




\section{B. Headquarters}

\section{Department Type of Assistance Time of Delivery Purpose}

$\begin{array}{llll}\text { MCM } & \text { Staff } & \text { December } 2010 & \text { Financial Sector } \\ \text { FAD } & \text { Staff } & \text { July } 2010 & \text { Expenditure and cash management } \\ \text { FAD } & \text { Staff } & \text { June } 2010 & \text { Petroleum products pricing } \\ \text { FAD } & \text { Staff } & \text { June } 2010 & \text { Revenue administration } \\ \text { MCM } & \text { Staff } & \text { May } 2010 & \text { Bank restructuring } \\ \text { FAD } & \text { Staff } & \text { September } 2009 & \text { Tax administration } \\ \text { FAD } & \text { Staff } & \text { May } 2009 & \text { Budget classification } \\ \text { FAD } & \text { Staff } & \text { October } 2008 & \text { Accounting reform }\end{array}$

\section{Resident Representative}

In February 2010, Mr. Abdourahmane Sarr became resident representative for Togo and Benin. 


\section{ApPendix II-Joint Management ACtion Plan}

1. The Fund Togo team led by Mr. Mills (mission chief) held a discussion with the World Bank Togo team led by Ms. Manuela Francisco (senior country economist) on March 7, 2011, to identify macro-critical structural reforms and coordinate the two teams' work for the period January 2011-December 2011.

2. The teams agreed that Togo's main macroeconomic challenges are to accelerate economic recovery, while maintaining sound policy to support financial and macroeconomic stability, particularly in the face of shocks. To meet these challenges, Togo needs to accelerate structural reforms (in particular in the financial and phosphate sectors and in the area of public financial management).

3. The teams have the following requests for information from their counterparts:

- The Fund team requests to be kept informed of progress in the above macrocritical structural reform areas and preparation of the Interim Strategy Note. Timing: when milestones are reached (and at least semi-annually).

- The Bank team requests to be kept informed of the Fund's assessments of macroeconomic policies and prospects.

4. Disbursement dates for general budget support targeted by staffs:

IMF:

SDR 8.8 million

July 22, 2011

World Bank:

SDR 18 million

April, 2011

5. The appendix Table 1 lists the teams' separate and joint work programs during December 2010-December 2011. 
Appendix Table 1. Togo: Bank and Fund planned activities in macro-critical structural reforms areas, December 2010-December 2011

\begin{tabular}{|c|c|c|c|}
\hline Title & Products & $\begin{array}{c}\text { Provisional } \\
\text { timing of } \\
\text { missions }\end{array}$ & $\begin{array}{l}\text { Expected delivery } \\
\text { date }\end{array}$ \\
\hline \multicolumn{4}{|c|}{ A. Mutual information on relevant work programs } \\
\hline \multirow{29}{*}{$\begin{array}{l}\text { World Bank work } \\
\text { program in the } \\
\text { next } 12 \text { months }\end{array}$} & Lending: & & \\
\hline & Community Development Project & & Ongoing \\
\hline & Education for All & & Ongoing \\
\hline & $\begin{array}{l}\text { Emergency Infrastructure Rehabilitation \& Energy } \\
\text { Project }\end{array}$ & & Ongoing \\
\hline & Financial Sector and Governance Project & & Ongoing \\
\hline & $\begin{array}{l}\text { DPO IV-Economic Recovery and Governance } \\
\text { Grant }\end{array}$ & & March 2011 \\
\hline & Private Sector Development Project & & March 2011 \\
\hline & Agriculture Sector Project & & April 2011 \\
\hline & West Africa Productivity Program & & March 2011 \\
\hline & $\begin{array}{l}\text { Emergency Urban Rehabilitation Additional } \\
\text { Financing }\end{array}$ & & May 2011 \\
\hline & Integrated Disaster and Land Management Project & & December 2011 \\
\hline & Infrastructure Additional Financing & & December 2011 \\
\hline & Community Development /Youth Employment & & March 2012 \\
\hline & $\begin{array}{l}\text { DPO V-Economic Recovery and Governance } \\
\text { Grant }\end{array}$ & & March 2012 \\
\hline & ECOWAS Broadband connectivity & & June 2012 \\
\hline & Economic and Sector Work: & & \\
\hline & Health Sector Review & & May 2011 \\
\hline & Country Environmental Analysis & & May 2011 \\
\hline & Energy Sector review & & December 2011 \\
\hline & Poverty/gender analysis & & June 2012 \\
\hline & Technical assistance/other analytical: & & \\
\hline & Strategic/financial audit of CEET & & April 2011 \\
\hline & Use of Country Systems & & June 2011 \\
\hline & ICT Strategy Development & & June 2011 \\
\hline & Post disaster Needs Assessment & & June 2011 \\
\hline & Cash for Work Program & & June 2011 \\
\hline & MDTF EITI & & June 2012 \\
\hline & Others: & & \\
\hline & Interim Strategy Note & & May 2011 \\
\hline \multirow{6}{*}{$\begin{array}{l}\text { IMF work } \\
\text { program in the } \\
\text { next } 12 \text { months }\end{array}$} & Lending: & & \\
\hline & $\begin{array}{l}\text { Sixth review under ECF and Article IV } \\
\text { consultations }\end{array}$ & $\begin{array}{l}\text { April-May } \\
2011\end{array}$ & $\begin{array}{l}\text { July } 2011 \text { (SR and } \\
\text { Board) }\end{array}$ \\
\hline & Additional Missions & & \\
\hline & $\begin{array}{l}\text { Possible conference reviewing 2008-2011 ECF } \\
\text { program (TBC) }\end{array}$ & $\begin{array}{l}\text { September } \\
2011(\mathrm{TBC})\end{array}$ & \\
\hline & $\begin{array}{l}\text { Staff monitoring or negotiation of new ECF } \\
\text { program }\end{array}$ & $\begin{array}{l}\text { October } \\
2011(\mathrm{TBC})\end{array}$ & December 2011 \\
\hline & Technical assistance: & & \\
\hline
\end{tabular}




\begin{tabular}{|c|c|c|}
\hline & $\begin{array}{l}\text { Financial Sector Development Strategy, Banking } \\
\text { sector restructuring and Asset Recovery } \\
\text { Company (MCM) }\end{array}$ & December 2010 \\
\hline & $\begin{array}{l}\text { Regional Workshop on Cash Flow Management } \\
\text { (MCM, STA, FAD) }\end{array}$ & February 2011 \\
\hline & National Accounts (AFRITAC West) & February 2011 \\
\hline & Tax Administration (AFRITAC West) & March 2011 \\
\hline & $\begin{array}{l}\text { Follow-up work on Financial Sector Development } \\
\text { Strategy, Banking sector restructuring and Asset } \\
\text { Recovery Company (AFRITAC West) }\end{array}$ & March 2011 \\
\hline & Government Finance Statistics (AFRITAC West) & April 2011 \\
\hline & $\begin{array}{l}\text { Treasury Management and Liquidity Forecasting } \\
\text { (AFRITAC West) }\end{array}$ & $\mathrm{TBC}$ \\
\hline & Tax Administration Reform Strategy (FAD) & TBC \\
\hline & Expenditure policy on social safety nets (FAD) & $\mathrm{TBC}$ \\
\hline & $\begin{array}{l}\text { Follow-up work on Financial Sector Development } \\
\text { Strategy, Banking sector restructuring and Asset } \\
\text { Recovery Company (AFRITAC West) }\end{array}$ & TBC \\
\hline & Debt management (AFRITAC West) & TBC \\
\hline & Balance of Payments Statistics (AFRITAC West) & $\mathrm{TBC}$ \\
\hline & National Accounts (AFRITAC West) & TBC \\
\hline & B. Requests for work program in & \\
\hline $\begin{array}{l}\text { Fund requests to } \\
\text { Bank }\end{array}$ & $\begin{array}{l}\text { Technical support and collaboration on expenditure } \\
\text { policy on social safety nets due to its significant } \\
\text { fiscal impact of measures to mitigate the impact of } \\
\text { increases in food and fuel prices on the poor. }\end{array}$ & \\
\hline $\begin{array}{l}\text { Bank request to } \\
\text { Fund }\end{array}$ & $\begin{array}{l}\text { Technical support and collaboration in the areas of } \\
\text { public finance management and the banking sector. }\end{array}$ & \\
\hline & C. Agreement on joint products and & \\
\hline $\begin{array}{l}\text { Joint Bank-Fund } \\
\text { products in the } \\
\text { next } 12 \text { months }\end{array}$ & Joint LIC Debt Sustainability Analysis & October 2011 (TBC) \\
\hline
\end{tabular}




\section{APPENDIX III-STATISTICAL ISSUES}

1. Data provision is broadly adequate for surveillance, but weaknesses in the quality and timeliness of data hamper staff's analysis. National accounts and balance of payments statistics are compiled based on very limited information, with only few surveys and scarce data on primary agriculture and private sector services. Moreover, government finance statistics are derived from a weak accounting and reporting system, and monetary data are reported by the BCEAO with a two-month lag.

2. The country has participated in the General Data Dissemination System (GDDS) since November 2001. Metadata on the national statistical system, including plans for improvement posted to the Fund's Dissemination Standard Bulletin Board, were last updated in December 2004.

\section{National accounts and consumer price index (CPI)}

3. Like other West African Economic and Monetary Union (WAEMU) member states, Togo had embarked in late 2002 on implementing the System of National Accounts 1993 (1993 SNA), using the ERETES software. The NA for the new base year (2000) were completed in 2005, but in 2006 due to a number of difficulties such as lack of staff, material and financial resources, the program was suspended and the NA for 2001 was not finalized. Only in March 2009 did the implementation process resume and the Direction Générale de la Statistique et de la Comptabilité Nationale (DGSCN) started working on the compilation of data for 2007 (the most recent year for which enough data was available). Since then, several AFRITAC West and AFRISTAT missions have assisted in the completion of data collection, in the preparation of source data, in ensuring consistency across primary data sources, and in preparing preliminary accounts. Estimates of production in the informal sector were also produced. The efforts related to end2010 population census exercise, which required the full attention of staff in the DGSCN, have further delayed the completion of the 2007 National Accounts. Furthermore, a May 2011 AFRITAC West TA report pointed to serious anomalies in the provisional 2007 NA (concerning value added in the informal sector, low fixed capital formation, high consumption to GDP ratio, among others), which were corrected during the mission. Authorities remain committed to achieving the objectives of finalizing the national accounts referring to the years up to 2010 before June 2012, despite the delays. The CPI basket was revised in 2010. The WAEMU commission, supported by AFRISTAT and the BCEAO, launched a revision of the harmonized CPI basket in the region in 2008. The reform included expanding CPI surveys, and updating the weights of various sub-components to reflect consumption habits.

\section{External sector statistics}

4. Balance of payments statistics and international investment position data are compiled based on bank reports, a survey of enterprises, and customs data. Statistics are compiled following the principles of the $5^{\text {th }}$ balance of payment manual, with a six-month delay and are revised twice a year. Export figures, net of transit trade, are appropriately reported since the latest STA technical assistance mission in balance of payments statistics in 2008. The Central bank continues its 
efforts for a better covering of informal trade notably with the subregional unit for the reconciliation of intra-WAMU trade. Data provided by BCEAO headquarters on the treatment of regional banknotes need to be reviewed at Headquarters level.

\section{Government accounts and public debt data}

5. The Government finance statistics accounting system is undergoing improvements. The new WAEMU budget nomenclature now permits the economic and ministerial classification of expenditure, with functional classification under development. The monthly TOFE (Table of Central Government Financial Operations) is based on a mixture of administrative and accounting data and is sent to AFR with a two-month lag. Inconsistencies in domestic arrears records held by different units of the Ministry of Finance and the stock of domestic debt have been audited and a new database is now set up. Comprehensive external debt data and projections on a loan by loan basis are compiled regularly. Only budgetary central government data are reported for publication in the Government Finances Statistics Yearbook (GFSY), government finance high frequency data are not reported for publication in the IFS.

\section{Monetary statistics}

6. Monthly data for Togo, along with data for other members of the West African Monetary Union are regularly disseminated by the Central Bank of the West African Monetary Union (BCEAO) with a lag of about two months. Data on lending and borrowing rates, charged by domestic banks, are now compiled and available monthly. 


\begin{tabular}{|c|c|c|c|c|c|}
\hline \multicolumn{6}{|c|}{$\begin{array}{l}\text { Togo: Table of Common Indicators Required for Surveillance } \\
\text { (As of June [30], 2011) }{ }^{2}\end{array}$} \\
\hline Economic Variable & $\begin{array}{l}\text { Date of latest } \\
\text { observation }\end{array}$ & $\begin{array}{l}\text { Date } \\
\text { received }\end{array}$ & $\begin{array}{l}\text { Frequency } \\
\text { of Data }^{2}\end{array}$ & $\begin{array}{l}\text { Frequency of } \\
\text { Reporting }^{2}\end{array}$ & $\begin{array}{l}\text { Frequency of } \\
\text { publication }^{2}\end{array}$ \\
\hline Exchange Rates & May 2011 & June 2011 & M & M & $\begin{array}{c}\text { Not } \\
\text { published }\end{array}$ \\
\hline $\begin{array}{l}\text { International Reserve Assets and } \\
\text { Reserve Liabilities of the Monetary } \\
\text { Authorities }\end{array}$ & March 2011 & May 2011 & M & M & $\begin{array}{c}\text { Not } \\
\text { published }\end{array}$ \\
\hline Reserve/Base Money & March 2011 & May 2011 & M & M & $\begin{array}{c}\text { Not } \\
\text { published }\end{array}$ \\
\hline Broad Money & March 2011 & May 2011 & M & M & $\begin{array}{l}\text { Not } \\
\text { published }\end{array}$ \\
\hline Central Bank Balance Sheet & March 2011 & May 2011 & M & M & $\begin{array}{l}\text { Not } \\
\text { published }\end{array}$ \\
\hline $\begin{array}{l}\text { Consolidated Balance Sheet of the } \\
\text { Banking System }\end{array}$ & March 2011 & May 2011 & M & M & $\begin{array}{l}\text { Not } \\
\text { published }\end{array}$ \\
\hline Interest Rates & January 2011 & April 2011 & M & Q & $\begin{array}{l}\text { Not } \\
\text { published }\end{array}$ \\
\hline Consumer Price Index & April 2011 & June 2011 & M & M & $\begin{array}{l}\text { Not } \\
\text { published }\end{array}$ \\
\hline $\begin{array}{l}\text { Revenue, Expenditure, Balance and } \\
\text { Composition of Financing - General } \\
\text { Government }\end{array}$ & n.a. & n.a. & M & M & $\begin{array}{l}\text { Not } \\
\text { published }\end{array}$ \\
\hline $\begin{array}{l}\text { Revenue, Expenditure, Balance and } \\
\text { Composition of Financing- Central } \\
\text { Government }\end{array}$ & March 2011 & June 2011 & M & M & $\begin{array}{l}\text { Not } \\
\text { published }\end{array}$ \\
\hline $\begin{array}{l}\text { Stocks of Central Government and } \\
\text { Central Government-Guaranteed Debt }\end{array}$ & $\begin{array}{l}\text { December } \\
2010\end{array}$ & April 2011 & M & M & $\begin{array}{l}\text { Not } \\
\text { published }\end{array}$ \\
\hline External Current Account Balance & December 2009 & March 2011 & A & OM & $\begin{array}{l}\text { Not } \\
\text { published }\end{array}$ \\
\hline $\begin{array}{l}\text { Exports and Imports of Goods and } \\
\text { Services }\end{array}$ & December 2010 & March 2011 & M & OM & $\begin{array}{c}\text { Not } \\
\text { published }\end{array}$ \\
\hline GDP/GNP & December 2009 & March & A & OM & $\begin{array}{c}\text { Not } \\
\text { published }\end{array}$ \\
\hline Gross External Debt & $\begin{array}{l}\text { December } \\
2010\end{array}$ & April 2011 & A & OM & $\begin{array}{l}\text { Not } \\
\text { published }\end{array}$ \\
\hline International Investment Position ${ }^{3}$ & 2009 & 2010 & & & \\
\hline
\end{tabular}




\section{INTERNATIONAL MONETARY FUND}

EXTERNAL

Public Information Notice (PIN) No. 11/100

FOR IMMEDIATE RELEASE

July 27,2011
International Monetary Fund

$70019^{\text {th }}$ Street, NW

Washington, D. C. 20431 USA

\section{IMF Executive Board Concludes 2001 Article IV Consultation with Togo}

On July 18, 2011, the Executive Board of the International Monetary Fund (IMF) concluded the Article IV consultation with Togo. ${ }^{1}$ The Executive Board also completed the sixth review of Togo's performance under its Extended Credit Facility (ECF) arrangement.

\section{Background}

Since the conclusion of the last Article IV consultation in April 2009, Togo has made further progress in overcoming the legacy of its protracted 1990-2005 domestic crisis. Despite an adverse global economic environment, growth has continued to accelerate, reaching 3.7 percent in 2010. Economic Growth nevertheless remains modest relative to population growth and to other countries in the region. Average inflation in 2010 remained modest at 1.4 percent, thanks largely to abundant local food production and limited pass-through of higher global oil prices. The current account deficit has widened owing to higher oil prices and imports of intermediate and capital goods, reflecting in part higher public investment

\footnotetext{
${ }^{1}$ Under Article IV of the IMF's Articles of Agreement, the IMF holds bilateral discussions with members, usually every year. A staff team visits the country, collects economic and financial information, and discusses with officials the country's economic developments and policies. On return to headquarters, the staff prepares a report, which forms the basis for discussion by the Executive Board. At the conclusion of the discussion, the Managing Director, as Chairman of the Board, summarizes the views of Executive Directors, and this summary is transmitted to the country's authorities. An explanation of any qualifiers used in summings up can be found here: http://www.imf.org/external/np/sec/misc/qualifiers.htm.
} 
spending. Public finances have strengthened markedly, given the external debt relief under the Highly Indebted Poor Countries Initiative (HIPC) and prudent fiscal policy.

The Togolese authorities have built a strong record of implementation of their IMFsupported economic program. With the conclusion of the sixth review of its ECF arrangement, Togo has successfully completed its three-year program in a timely manner. In 2010, budget execution was particularly strong, with all fiscal performance criteria met by ample margins. Revenue collection improved, and current expenditures remained within program ceilings. The execution of priority social spending and of capital projects improved substantially in 2010 , nearly reaching ambitious targets.

The conduct of fiscal policy in 2011 was complicated by the mounting subsidies following the non-adjustment of fuel pump prices, notwithstanding global higher prices. In June, the authorities began gradual fuel price adjustments and initiated targeted social measures, developed in consultation with stakeholders, to cushion the impact on the vulnerable population. To offset partially the budgetary cost of fuel subsidies, the authorities postponed some lower-priority investment spending to 2012. Overall, the budget stance has become somewhat more accommodative in 2011, targeting a domestic primary deficit of 1.6 percent of GDP, rather than 0.4 percent previously. Fiscal balances for 2008-2011 have nevertheless remained consistent on average with the authorities' initial target for the program, as a result of the overperformance in 2010.

Structural reforms to address weaknesses stemming from the domestic crisis have advanced since 2009, although progress has been slower than planned in some key areas. While improvements in public financial management have generally proceeded well, reform efforts have not yet yielded desired results in other sectors, such as phosphates and banking. In particular, the privatization process for the four largest state-owned banks-a key step to improve their soundness, protect public finances and promote financial intermediation -is taking longer than anticipated, in part due to the need to establish an inclusive consultative mechanism to make strategic choices on the privatization process. Following these decisions, the authorities re-energized the privatization process by issuing a call for expressions of interest in the local and international media. The authorities remain committed to seeking strategic investors and aim to bring the banks to the point of sale before end-2011.

For the medium-term, the authorities are emphasizing policies to strengthen the foundations for growth. To address infrastructure bottlenecks, the authorities intend to scale up public investment by around $2 \frac{1}{2}$ percent of GDP a year in 2012-2014, while maintaining macroeconomic stability and debt sustainability. With the objective of mobilizing more domestic resources for priority social and investment spending, the authorities intend to redouble efforts to modernize tax and customs administration and reduce tax exemptions.

Despite Togo's considerable progress in economic stabilization, it remains vulnerable, and risks persist. Worsening of external price shocks would lead to deterioration in growth, the current account, price stability, and the budget. Persistent constraints in administrative 
capacity could delay implementation of reforms designed to address key obstacles to growth, thereby postponing recovery.

\section{Executive Board Assessment}

Executive Directors agreed with the thrust of the staff appraisal. They commended the authorities for the strong track record and successful completion of the ECF-supported program, despite the adverse shocks and limited administrative capacity. Economic growth has picked up, bolstered by countercyclical fiscal policy in 2010 and progress in implementing the reform agenda. Directors stressed that continued commitment to preserve fiscal sustainability and address underlying structural weaknesses is critical to boosting growth potential. They welcomed the authorities' intention to remain closely engaged with the Fund and development partners in order to consolidate the gains achieved thus far.

Directors welcomed the implementation of the automatic mechanism for adjusting retail prices for oil products, accompanied by targeted measures to cushion the social impact. They supported the emphasis of the medium-term fiscal framework on scaling up investment in infrastructure and priority social spending. Directors underscored the need to be vigilant about potential shortfalls in revenue and the quality of public projects. Adopting a rules-based framework anchored on the fiscal deficit and debt level would be helpful in this regard. Directors encouraged further efforts to strengthen public financial management, revenue collection, and management of contingent liabilities, with technical support from development partners. They noted that Togo remains at moderate risk of debt distress, calling for improved capacity in debt management, and a financing strategy that relies on grants and highly concessional loans.

Directors considered speeding up bank privatization to be central to the reform agenda-a key step to improve access to credit and promote private sector growth. They also stressed that a financial sector development strategy is a high priority in this area, and welcomed its preparation in cooperation with stakeholders and with technical assistance from the Fund. Directors underlined the importance of broader and deeper structural reforms to boost competitiveness and productivity growth, and reduce poverty. Efforts should focus on improving the business climate, increasing investment in physical and human capital, and enhance governance in public sector operations. Directors noted that membership in the West African Economic and Monetary Union has provided an important anchor of stability, particularly in the face of recent external shocks. 
95

Public Information Notices (PINs) form part of the IMF's efforts to promote transparency of the IMF's views and analysis of economic developments and policies. With the consent of the country (or countries) concerned, PINs are issued after Executive Board discussions of Article IV consultations with member countries, of its surveillance of developments at the regional level, of post-program monitoring, and of ex post assessments of member countries with longer-term program engagements. PINs are also issued after Executive Board discussions of general policy matters, unless otherwise decided by the Executive Board in a particular case. 
Togo: Selected Economic and Financial Indicators, 2009-13

\begin{tabular}{|c|c|c|c|c|c|}
\hline & 2009 & 2010 & 2011 & 2012 & 2013 \\
\hline & Actual & Est. & Proj. & Proj. & Proj. \\
\hline & \multicolumn{5}{|c|}{ (Percentage growth, unless otherwise indicated) } \\
\hline \multicolumn{6}{|l|}{ National income, prices, and exchange rates } \\
\hline Real GDP & 3.2 & 3.7 & 3.9 & 4.5 & 4.7 \\
\hline Real GDP per capita & 0.7 & 1.1 & 1.3 & 1.9 & 2.2 \\
\hline GDP deflator & 1.9 & 1.8 & 3.8 & 2.7 & 2.4 \\
\hline Consumer price index (average) & 1.9 & 1.4 & 4.3 & 2.6 & 2.4 \\
\hline GDP (CFAF billions) & 1,490 & 1,573 & 1,696 & 1,821 & 1,952 \\
\hline Exchange rate CFAF/US\$ (annual average level) & 470.7 & 494.2 & $\ldots$ & $\ldots$ & $\ldots$ \\
\hline Real effective exchange rate & 0.3 & -6.0 & $\ldots$ & $\cdots$ & $\ldots$ \\
\hline \multirow[t]{2}{*}{ Terms of trade (deterioration $=-$ ) } & 4.8 & -0.2 & -1.6 & -1.6 & -0.4 \\
\hline & \multicolumn{5}{|c|}{$\begin{array}{c}\text { (Annual change, percent of beginning-of-period broad } \\
\text { money) }\end{array}$} \\
\hline \multicolumn{6}{|l|}{ Monetary survey } \\
\hline Net foreign assets ${ }^{1}$ & 0.7 & 3.0 & 2.1 & -0.2 & 0.8 \\
\hline Credit to government ${ }^{1}$ & 6.4 & 3.0 & 4.8 & 1.4 & 1.9 \\
\hline Credit to nongovernment sector & 9.7 & 10.3 & 8.5 & 6.8 & 6.4 \\
\hline Broad money (M2) & 16.2 & 16.3 & 11.6 & 10.3 & 9.2 \\
\hline Velocity (GDP/end-of-period M2) & 2.4 & 2.2 & 2.1 & 2.1 & 2.0 \\
\hline & \multicolumn{5}{|c|}{ (Percent of GDP, unless otherwise indicated) } \\
\hline \multicolumn{6}{|l|}{ Investment and savings } \\
\hline Gross domestic investment & 18.0 & 18.9 & 19.4 & 21.8 & 22.7 \\
\hline Government & 5.5 & 7.9 & 8.9 & 11.5 & 12.6 \\
\hline Nongovernment & 12.5 & 11.0 & 10.5 & 10.3 & 10.1 \\
\hline Gross national savings & 11.4 & 11.7 & 11.7 & 13.7 & 14.4 \\
\hline Government & 2.7 & 6.2 & 5.0 & 7.4 & 7.0 \\
\hline Nongovernment & 8.7 & 5.4 & 6.8 & 6.4 & 7.3 \\
\hline \multicolumn{6}{|l|}{ Government budget } \\
\hline Total revenue and grants & 18.5 & 20.9 & 22.2 & 22.7 & 22.7 \\
\hline Revenue & 16.9 & 18.9 & 18.9 & 18.4 & 18.5 \\
\hline Total expenditure and net lending & 21.3 & 22.5 & 26.1 & 26.8 & 28.3 \\
\hline Domestic primary expenditure & 17.4 & 16.7 & 20.4 & 19.5 & 20.2 \\
\hline Overall balance (payment order basis) & -2.8 & -1.6 & -3.9 & -4.1 & -5.6 \\
\hline Domestic primary balance ${ }^{2}$ & -0.4 & 2.2 & -1.6 & -1.1 & -1.7 \\
\hline Change in domestic arrears & -1.0 & -2.3 & -0.8 & -0.3 & -0.3 \\
\hline \multicolumn{6}{|l|}{ External sector } \\
\hline Current account balance & -6.6 & -7.2 & -7.6 & -8.1 & -8.3 \\
\hline Exports (goods and services) ${ }^{3}$ & 36.8 & 37.3 & 37.4 & 37.1 & 37.2 \\
\hline Imports (goods and services) ${ }^{3}$ & -52.5 & -53.8 & -55.1 & -55.8 & -56.0 \\
\hline External public debt ${ }^{4}$ & 52.7 & 17.2 & 16.0 & 17.1 & 19.2 \\
\hline External public debt service (percent of exports) ${ }^{4}$ & 4.6 & 5.1 & 2.9 & 2.9 & 3.1 \\
\hline Total public debt ${ }^{4}$ & 67.8 & 32.3 & 27.4 & 27.1 & 27.8 \\
\hline
\end{tabular}

Sources: Togolese authorities and IMF staff estimates and projections.

${ }^{1}$ Change as a percentage of broad money at the beginning of the period.

${ }^{2}$ Revenue minus expenditure, excluding grants, interest, and foreign-financed expenditure.

${ }^{3}$ Aggregate import and export figures, both for historical data and for projections, now include separately the imports and exports from the binational electricity generating company CEB, which were previously netted out when calculating aggregate numbers.

${ }^{4}$ Includes arrears and state-owned enterprises external debt. 


\section{INTERNATIONAL MONETARY FUND \\ EXTERNAL \\ RELATIONS \\ DEPARTMENT}

Press Release No. 11/285

FOR IMMEDIATE RELEASE

International Monetary Fund

July 18, 2011

Washington, D.C. 20431 USA

\section{IMF Executive Board Completes Sixth and Final Review Under the ECF Arrangement for Togo and Approves US\$13.95 Million Disbursement}

The Executive Board of the International Monetary Fund (IMF) today completed the sixth and final review of Togo's economic program supported by the Extended Credit Facility (ECF). The approval will enable an immediate disbursement in an amount equivalent to SDR 8.8 million (about US\$13.95 million), bringing total disbursements under the arrangement to an amount equivalent to SDR 95.41 million (about US\$151.21 million).

The Executive Board also concluded the 2011 Article IV consultation. Details of the findings of the Article IV will be published in a Public Information Notice in due course.

The ECF Arrangement for Togo was approved on April 21, 2008 (See Press Release No. 08/90). The authorities have requested the opening of discussions on a successor IMF-supported economic program.

Following the Executive Board's discussion, Ms. Nemat Shafik, Deputy Managing Director and Acting Chair, said:

"The Togolese authorities have maintained a strong track record of program implementation. The strong budget execution in 2010 was commendable. The execution of domestically financed public investment and priority social spending has improved. Growth has picked up in large part as a result of these developments.

"After delaying the pass-through of higher global oil prices to consumers, the authorities began implementing the automatic pricing mechanism in June, to limit the budgetary impact of the fuel subsidies. The mechanism aims to minimize economic distortions and safeguard public finances, while targeted measures cushion the social impact of higher fuel prices.

"The medium-term budget framework appropriately emphasizes increasing public investment to support growth, to be financed largely by domestic revenue, grants, and highly concessional external loans. This ambitious approach puts a premium on the quality of investment projects, public financial management reforms and revenue administration efforts. 
"The authorities are committed to accelerating broad-based structural reforms aimed at boosting competitiveness and potential growth. It is particularly important to proceed expeditiously with the recently reinvigorated privatization process for the four largest state-owned banks, which will lead to a sounder and more efficient banking sector. Other priorities are maintaining a sustainable fiscal policy, reforming public enterprises, increasing investment in physical and human capital, and improving the business climate," Ms. Shafik added. 


\section{Statement by Kossi Assimaidou, Executive Director for Togo Monday, July 18, 2011}

\section{INTRODUCTION}

I would like to thank the Executive Board, Management and Staff for their continued support to my Togolese authorities in their efforts to implement sound policies and far-reaching reforms under the ECF-supported program. Fund's support and my authorities' firm commitment to the program led Togo to meet the HIPC completion point requirements and to receive debt relief under the HIPC and MDRI initiatives in 2010. In addition, Togo has reengaged with the international community and restored macroeconomic stability while broader economic performance is improving. My Togolese authorities are particularly pleased by the successful completion of their first three-year (2008-2011) economic program supported by the ECF.

Going forward, my authorities remain determined to persevere with prudent policies and deepen structural reforms while continuing to benefit from the support of the Fund and other partners. In this regard, the authorities request the opening of discussions for a new IMF-supported program in order to further strengthen their current reform agenda, enhance public finance management, and promote the development of a strong financial sector.

\section{RECENT DEVELOPMENTS AND PROGRAM IMPLEMENTATION}

The Togolese economic performance has continued to improve despite the difficult external environment, which includes regional instability, the slow recovery of the world economy, and the surge in international fuel and food prices. Real GDP growth has increased to reach 3.7 percent in 2010 and is projected to increase further to 3.9 percent in 2011, reflecting, among others, the recovery in the cotton sector coupled with buoyant activity at the Port Autonome de Lomé and public investments in infrastructure. Inflation declined to 1.4 percent in 2010 from 1.9 percent in 2009. The current account deficit increased slightly to 7.2 percent of GDP from 6.6 percent in 2009 following the drop in phosphate exports and the rising international fuel and food prices. Significant increase in imports of intermediate and capital goods for infrastructure projects has also contributed to widening the external deficit.

In the fiscal area, performance in 2010 was strong, as targets set out in the program were met with considerable margins. Total revenue increased by 17.6 percent in 2010 , exceeding the program's objectives owing to the economic recovery and improved efficiency of tax administration. Public expenditure was executed within the program's ceilings. No external arrears were accumulated and no nonconcessional external debt contracted. Payments of commercial arrears due to domestic creditors have also been pursued. Considerable progress has been made in the fiscal reform area since the last program review in December 2010, which was 
instrumental in meeting the objectives of the ECF-supported program. In December 2010, the authorities have established the treasury committee that has become operational since then.

On structural reforms, the authorities have completed a financial and organizational audit of the public sector workers' pension fund, as well as the subsequent actuarial study on it, with the view to tackling the pension system sustainability problem. Regarding the privatization process of state-owned banks, my authorities have very recently issued a call for expressions of interest. Other structural measures - notably the adoption of a roadmap for the establishment of a onestop window at the Port and the setting up of a mechanism to recover non performing loanshave seen progress in implementation. A few measures encountered delays, mostly due to technical capacity constraints, as well as legal and consultative process requirements taking longer than initially envisaged. These processes are nevertheless necessary to establish firm legal ground and broad public support for reform.

Based on the continued good performance of Togo in implementing its program and the authorities' strong commitment to pursue implementing structural reforms to accelerate growth and preserve macroeconomic stability, I request Directors' support for the completion of the sixth review of Togo's program under the ECF arrangement.

\section{III.POLICIES AND REFORMS FOR 2011}

\section{Fiscal policy}

My Togolese authorities will continue to build on the strong record of fiscal policy and structural reform implementation. In this respect, the basic framework of the 2011 budget discussed with staff will guide their policy measures and reforms despite the difficult environment marked by the rising international oil and food prices.

Mindful of the need to stem the budgetary strains resulting from the global changes in the fuel prices in particular, the authorities have begun implementing an automatic petroleum price adjustment mechanism to reflect the market prices and preserve government finances. The decision to implement this adjustment mechanism was reached after a far-reaching social dialogue on the impact of this policy and accompanying measures notably in favor of the most vulnerable segments of the population. Accordingly, pump prices were adjusted in June. More recently, significant social demands - reminiscent of the movements that led to violent protests in 2009- have risen, including demands for greater government support to vulnerable populations in face of the unprecedented costs of petroleum products. My authorities favor a pragmatic approach to responding to these social demands. To offset partially the budgetary cost of the delay in passing through changes in international oil prices, the authorities have identified, in consultation with staff, expenditures that could be deferred to the 2012 budget. 
Based on these changes, the expenditure and revenue targets have been revised for 2011. The authorities will make every effort to collect all the budgeted nontax revenue while remaining vigilant with regard to the performance of the state-owned enterprises. Despite the considerable time required to put in place an adequate regulatory framework, the authorities plan to complete the sale of the third mobile telephone license.

Based on these measures, the domestic primary deficit was also revised. Nevertheless, this budgetary framework remains consistent with the authorities' objectives for growth and the sustainability of public finances. Strongly determined to continue improving the monitoring of budget execution, the authorities have updated the quarterly indicative targets on the execution of the 2011 budget. They will also continue to ensure strict compliance with the ceilings on projected current investment expenditure while paying due attention to the consistency of the budget execution with the availability of financing.

\section{Borrowing and public debt management strategy}

In order to further enhance the sustainability of Togo's external indebtedness, the authorities will pursue a prudent fiscal policy. They also remain committed to prudent borrowing and sound public debt management. In this regard, they will continue to rely on grants and concessional loans for external financing. In addition, the SOEs have begun to report regularly information on their external borrowing to the Ministry of Economy and Finance with a view to ensuring that their borrowing is consistent with the government's external loan policy.

\section{Financial sector reform}

My authorities agree with the need to develop a vibrant and sound financial system to further increase the financing of the private sector development. To this end, they have initiated, with the support of development partners including the Fund, a process for developing a financial sector development strategy. In order to discuss and validate this strategy, a national workshop is planned to take place in September 2011.

The Togolese authorities remain committed to privatizing the four state owned-banks as reflected by the issuance of a presidential decree stating the government's privatization strategy. Under this strategy, the majority of banks' capital will be allocated to strategic investors. Following this important step in the banks' privatization process, the authorities published on July 7, 2011 in the national and international press a pre-qualification notice in the form of advertisement for the privatization of the four banks namely BIA-Togo, BTCI, BTD and UTB. The demands for the pre-qualification should be transmitted to the Privatization National Commission by September 9,2011 . The authorities intend to use the receipts from the bank privatization to repay the domestic debt, in particular, the securities issued as part of the bank restructuring process. In the meantime, they will continue maintaining strict control over the management of these banks, in 
close collaboration with the WAMU Banking Commission and until the completion of the privatization process.

Furthermore, following the workshop held in March 2011 to validate the financial and organizational audit as well as the actuarial study of the Togo Retirement Fund (CRT), the authorities are analyzing the recommendations of the reports with a view to ensuring their adequate implementation.

\section{Structural reforms and competitiveness}

The Togolese authorities will continue focusing their efforts on needed structural reforms to sustain macroeconomic stability, increase growth and reduce poverty, and preserve competitiveness.

Efforts to establish a single treasury account are underway, and technical assistance from the IMF and the collaboration of development partners will be required, given the impact of the measure on the projects' accounts. The reforms of Togo's public finance systems are continuing with the support of the African Development Bank, the European Union and the IMF. The action plan drawn to implement these reforms is now being implemented and the transposition of WAEMU directives on public financial management into national legal provisions is underway. The government will adopt the new customs code by end-2011.

In their efforts to simplify the procedures at the Port Autonome de Lomé, the authorities have decided to accelerate the creation of the "one stop window". Despite the delays experienced in this endeavor, the authorities remain committed to completing this measure as soon as the roadmap identifying the steps necessary for this initiative and related recommendations are available by end-July 2011.

With regard to the Compagnie Energie Electrique du Togo (CEET), the authorities are committed to completing an electricity tariff-setting policy taking into account the company's cost and aiming to maintain its financial viability and to minimize fiscal risks. In this respect, a tariff increase by a weighted average of 20 percent was introduced in January 2011. In addition, the authorities will pursue their efforts to further improve the governance of the company.

Given the need to improve the country's infrastructure and meet its development challenges, the authorities plan to speed up the implementation of their public investment program while preserving macroeconomic stability and strengthening the business environment.

\section{CONCLUSION}

My Togolese authorities appreciate the constructive cooperation with the IMF, which under the implementation of the ECF-supported program has played a decisive role in enhancing the public 
finance management, restoring economic growth and confidence in Togo, and deepening structural reforms. They are strongly committed to consolidate the gains made under the ECFsupported program. In this respect, they look forward to opening negotiations for a new Fundsupported arrangement. They intend to hold a high-level seminar to draw lessons from the current program, with the broad participation of all and the support of the Fund. My authorities are also hopeful that the Fund, other international financial institutions and development partners will continue to assist them in their efforts. 